Columbia Law School

Scholarship Archive

2013

\title{
The Shale Oil and Gas Revolution, Hydraulic Fracturing, and Water Contamination: A Regulatory Strategy
}

Thomas W. Merrill

Columbia Law School, tmerri@law.columbia.edu

David M. Schizer

Columbia Law School, david.schizer@law.columbia.edu

Follow this and additional works at: https://scholarship.law.columbia.edu/faculty_scholarship

Part of the Environmental Law Commons, and the Water Law Commons

\section{Recommended Citation}

Thomas W. Merrill \& David M. Schizer, The Shale Oil and Gas Revolution, Hydraulic Fracturing, and Water Contamination: A Regulatory Strategy, 98 MiNN. L. REV. 145 (2013).

Available at: https://scholarship.law.columbia.edu/faculty_scholarship/837

This Article is brought to you for free and open access by the Faculty Publications at Scholarship Archive. It has been accepted for inclusion in Faculty Scholarship by an authorized administrator of Scholarship Archive. For more information, please contact scholarshiparchive@law.columbia.edu. 


\section{Article}

\section{The Shale Oil and Gas Revolution, Hydraulic Fracturing, and Water Contamination: A Regulatory Strategy}

\section{Thomas W. Merrill \& David M. Schizer ${ }^{\dagger}$}

Introduction

I. Hydraulic Fracturing: A Technological Leap in Drilling for Shale Oil and Gas

II. Economic, National Security, and Environmental

Benefits from Fracturing

A. Economic Growth ........................................................ 157

B. Energy Independence and National Security ......... 161

C. Environmental Benefits: Air Quality and

Climate Change

1. Cleaner Air from Using Gas Instead of Coal .... 164

2. Climate Change: Reduced Greenhouse Gas Emissions from Burning Gas Instead of Coal... 165

3. Climate Change: Offsetting Effects of Fugitive Methane Emissions.

III. Familiar Risks That Are Not Unique to Fracturing ........ 170

A. Economic Competition for Solar, Wind, and Other Renewables.

B. Air Pollution

C. Congestion and Pressure on Local Communities... 176

D. Water Usage.

$\dagger$ The authors are, respectively, Charles Evans Hughes Professor, Columbia Law School, and Dean and the Lucy G. Moses Professor of Law, and Harvey R. Miller Professor of Law and Economics, Columbia Law School. We are grateful for comments at workshops presented at Brooklyn and Columbia Law Schools, and from Alan Bernstein, Jason Bordoff, Travis Bradford, Al Cinelli, Colin Davies, Robert Ferguson, Joey Fishkin, Mark Geistfeld, Kent Greenawalt, Michael Gerrard, Suzanne Goldberg, Geoff Heale, Susan Kraham, Brian Lee, Minor Myers, Ben Liebman, Ed Lloyd, Irv Rotter, Chuck Sabel, Fred Schauer, Peter Schuck, Cathy Sharkey, Charles Stanley, Peter Strauss, David Trice, Hannah Wiseman, Daniel Yergin, and Ben Zipursky. Copyright $\mathbb{C} 2013$ by Thomas W. Merrill and David M. Schizer. 
E. Induced Tremors and Earthquakes..........................179

IV. Novel Risks of Water Contamination ................................ 180

A. First Risk: Fracturing Fluid .................................... 181

1. First Fracturing Fluid Risk: Migration

Through Subsurface Cracks ............................. 182

2. Second Fracturing Fluid Risk: Surface Spills... 184

3. Third Fracturing Fluid Risk: Flow-Back and Produced Water

4. Fourth Fracturing Fluid Risk: Cracked Well

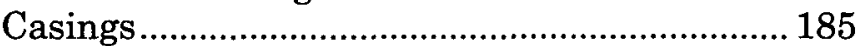

5. Fifth Fracturing Fluid Risk: Blowouts .............. 186

6. Studies on the Magnitude of These FrackingFluid Risks

B. Second Risk: Contamination of Water Wells with

Methane.

C. Third Risk: Disturbance of Sludge or Other

Residues in Wells Due to Fracturing

D. Fourth Risk: Fracturing Waste and Produced

Water-Injection Wells and Sewage Facilities....... 195

E. The Existing Regulatory Regime

1. State and Local Law ........................................... 197

2. Federal Law ............................................................ 200

V. Choosing a Regulatory Strategy for Water Contamination 201

A. The Danger of Regulatory Overkill ..........................202

1. Public Anxiety and Love Canal .........................202

2. Precautionary Principle ...................................... 204

B. Five Possible Regulatory Strategies......................... 206

1. Prohibitions .........................................................206

2. Command and Control Regulation ....................206

3. Disclosure.........................................................208

4. Liability Rules ..................................................209

5. Coasean Bargains................................................. 210

C. Four Factors Influencing the Choice of

Regulatory Strategy...............................................211

1. Heterogeneity of Risk........................................ 213

2. Magnitude of Expected Harm ............................214

3. "Settlement" Costs of Ex Post Judgments......... 214

4. Novelty of Risk ...................................................215

D . Applying these Factors to the Risk of Water

Pollution from Fracturing .......................................216

1. Heterogeneity of Risk........................................216

2. Magnitude of Expected Harm ............................219

3. Settlement Costs .................................................. 221 
4. Novelty of Risk

E. The Regulatory Strategy for Water

Contamination from Fracturing

1. The Need for Both Best Practices Regulation and Liability

2. Three Rules to Coordinate Liability with Best Practices Regulation

3. The Supporting Role of Prohibitions, Disclosure, and Coasean Bargains.

VI. Designing a Regulatory Regime for Water

Contamination 224

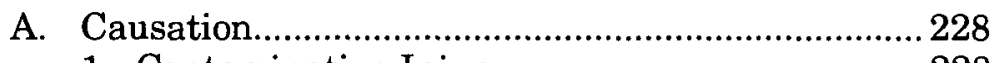

1. Contamination Injury ......................................228

2. Pathway of Causation .........................................2235

3. The Scope of the Harm........................................2236

B. Standard of Care ....................................................238

1. Our Hybrid Proposal ......................................... 239

2. Comparison of Strict Liability, Negligence, and Our Hybrid Proposal: Five Factors............. 239

C. Plaintiff Fault and Releases from Liability ............246

D. Measure of Damages ...............................................247

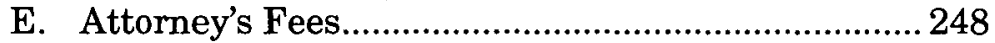

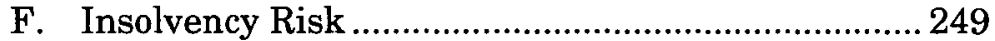

VII. Implementation Options .................................................250

A. Jurisdictional Scope................................................251

1. Historical Practice..............................................2251

2. Policy Justifications for State Regulation .........253

B. Implementing Body ...............................................257

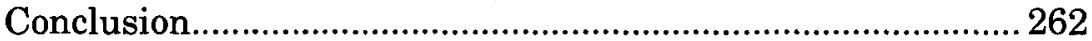

\section{INTRODUCTION}

The United States has surpassed Russia as the world's top natural gas producer,' and according to the world's most respected energy forecaster, the U.S. will also overtake Saudi Arabia as the largest oil producer by $2020{ }^{2}$ This surge in U.S.

1. BP, STATISTICAL REVIEW OF WORLD ENERGY, JUNE 201322 (2013), available at http://www.bp.com/content/dam/bp/pdf/statistical-review/ statistical_review_of_world_energy_2013.pdf (U.S. production in 2012 was 681.4 billion cubic meters, compared with 592.3 for Russia).

2. INT'L ENERGY AGENCY, WORLD ENERGY OUTLOOK 2012 23, 138 (2012) [hereinafter IEA, WORLD ENERGY OUTLOOK 2012], available at http:// iea.org/publications/freepublications/publication/English.pdf; see also LEONARDO MAUGERI, BELFER CTR. FOR SCI. \& INT'L AFFAIRS, HARVARD 
oil and gas production would have seemed wildly improbable a decade ago. It flows from a revolution in U.S. oil and gas production. Energy companies have learned to tap previously inaccessible oil and gas in shale and other impermeable (or "tight") rock formations. ${ }^{3}$ To do so, they use "hydraulic fracturing" ("fracturing" or "fracking"), pumping fluid into shale at high pressure to crack the rock and release gas and oil trapped inside. This "shale revolution" has created high-paying drilling jobs, revived the petrochemicals industry as well as other domestic manufacturing, improved our balance of payments, and increased the competitiveness of the United States in the global economy. It has also reduced our reliance on energy imports and enhanced our energy security. In addition, the shale revolution has enabled the United States to reduce greenhouse gas emissions over the past seven years-the largest reduction anywhere-by substituting natural gas for coal.

Fracturing is controversial. By reducing the price of natural gas, it may undercut the fledgling renewable energy industry, at least in the near term. The fracturing boom may also exacerbate air pollution, traffic and congestion. The technology uses significant amounts of water, and some aspects of fracturing operations may induce tremors and minor earthquakes. In all these regards, fracturing is not unique, since each of these risks arises in conventional oil and gas drilling and, for that matter, in other economic activity as well.

The most unique risk associated with fracturing, which has generated widespread public apprehension, ${ }^{4}$ is the potential

KENNEDY SCH., OIL: THE NEXT REVOLUTION 42 (2012).

3. IEA, WORLD ENERGY OUTLOOK 2012, supra note 2, at 75 . In addition to shale oil and shale gas, the analysis in this Article also applies to "tight sands gas" and "tight oil," which are found in sandstone, coal seams and carbonate. IHS GLOBAL INSIGHT, AMERICA'S NEW ENERGY FUTURE: THE UNCONVENTIONAL OIL AND GAS REVOLUTION AND THE US ECONOMY: NATIONAL ECONOMIC CONTRIBUTIONS 12 (2012) Thereinafter IHS, NATIONAL ECONOMIC CONTRIBUTIONS]. For simplicity's sake, we use the phrase "shale oil and gas" to cover all these sources of unconventional oil and gas.

4. See, e.g., EPA, STUDY OF THE POTENTIAL IMPACTS OF HydRaUlic FRACTURING ON DRINKING WATER RESOURCES: PROGRESS REPORT 1 (2012) [hereinafter EPA 2012 PROGRESS REPORT], available at http://www.epa.gov/ hfstudy/pdfs/hf-report20121214.pdf (" $[\mathrm{A}] \mathrm{s}$ the use of hydraulic fracturing has increased, so have concerns about its potential human health and environmental impacts, especially for drinking water ... ."); ERNEST J. MONIZ, HENRY D. JACOBY \& ANTHONY J.M. MEGGS, MIT STUDY ON THE FUTURE OF NATURAL GAS 37 (2011), available at http://mitei.mit.edu/system/files/NaturalGas Report.pdf [hereinafter 2011 MIT STUDY] (describing popular anxiety about the fact that "the fracturing process risks injecting toxic fracture fluids into 
contamination of groundwater. The fluid used in fracturing contains toxic chemicals. In a sense, this risk is also not new. Although fracturing in shale has developed in the past decade, fracturing has been used in conventional drilling for over sixty years, so that two million wells have been "fracked" in the U.S. There is little evidence so far that subterranean fracturing activity can directly contaminate groundwater. The layer of shale that is fractured is usually thousands of feet below the water table, with a buffer of dense rock or clay in between. But other risks to groundwater may prove to be more meaningful, including surface spills of fracturing fluid, improper handling of waste products, and the migration of natural gas into water wells. In response, we need effective regulation. Since fracturing in shale began fairly recently, the regime for dealing with some of these risks is not yet fully developed.

This Article considers how to regulate this risk of water contamination. The task entails a careful balance of competing considerations. The shale boom offers enormous benefits and should be encouraged. At the same time, we need regulation to ensure that it is safe, since water is a vitally important resource. In addition, the public must believe that shale drilling is safe. Otherwise, the shale revolution could be vulnerable to regulatory overkill, as media stories about flaming water faucets, brown well water, and sickly farm animals prompt widespread public apprehension about water contamination. In order to realize the potential benefits of fracturing, we need regulation that is carefully calibrated to minimize the real risks, without deterring socially valuable drilling.

This challenge is all the more difficult because fracturing can potentially contaminate water in several ways. Some are well understood from decades of conventional oil and gas production and can be controlled with best practices regulations.

shallow groundwater aquifers, which are in many cases the source of potable water for public use"); Mireya Navarro, Gas Drilling Jitters Unsettle Catskills Sales, N.Y. TIMES, Sept. 30, 2012, at RE 1, 6 (noting that the possibility of fracturing and its related water contamination risk has unsettled Catskills real estate market); Lucija Muehlenbachs, Elisheba Spiller \& Christopher Timmins, Shale Gas Development and the Costs of Groundwater Contamination Risk (Res. for the Future, Working Paper 2013), available at http://rff .org/RFF/Documents/RFF-DP-12-40-REV.pdf (studying residential property values in Washington County, PA and finding "that properties are positively affected by the drilling of a nearby shale gas well-relative to the overall change in economic activity within the county-unless the property depends on groundwater, in which case the risk to groundwater (whether real or perceived) more than fully offsets these gains"). 
Others are highly speculative, may or may not present real risks, and currently have no known solutions. As a result, regulatory responses should be dynamic, generating additional information about potential risks and stimulating innovations to reduce these risks. ${ }^{5}$

One element of our strategy is an evolving body of best practices regulations designed to reduce the risks of water contamination. Rules based on "best available" technology have a double advantage over other regulatory strategies. First, bestpractices regulation reassures the public that a responsible regulatory body is focused on the issue and has directed the use of state-of-the-art control measures. Second, although best practices regulation may not always be optimally efficient, it provides industry with a significant measure of certainty. Given the substantial investments required to exploit shale oil and gas, the regulatory regime has to be relatively predictable.

At the same time, best practices regulation has two major shortcomings in the context of the shale revolution. First, the body of regulations will remain incomplete for the foreseeable future because fracturing in shale poses new risks that are not yet fully understood. Therefore, we need to provide a fallback source of protection, and also to create incentives for regulators and industry to close these regulatory gaps. Second, best practices regulations are only as effective as the mechanisms for enforcing them. If penalties are low and inspections are infrequent, best practices regulation will offer only limited protection. Thus, it is important to build in incentives to encourage compliance.

To capture the advantages of best practices regulation while minimizing its disadvantages, we propose to backstop best practices regulation with liability rules. Specifically, we need a liability rule for three different situations. First, assume water is contaminated by a problem that is, in fact, governed by best practices regulations. If the energy company has not complied with these regulations, it should be liable. Second (and conversely), if the company has complied, this should be a de-

5. To borrow a term favored by some of our colleagues, the regime should be "experimentalist." See, e.g., Charles F. Sabel \& William H. Simon, Contextualizing Regimes: Institutionalization as a Response to the Limits of Interpretation and Policy Engineering, 110 MICH. L. REV. 1265, 1298 (2012); Charles F. Sabel \& William H. Simon, Minimalism and Experimentalism in the Administrative State, 100 GEO. L.J. 53, 55 (2011). With respect to regulation of the shale revolution, not only the specific control measures but the entire regulatory regime should be adaptive. See infra Part VII. 
fense against claims that it should have done more (although we would not allow this defense if the regulation falls significantly below industry norms). Third, what if there are no best practices regulations governing the particular circumstances that caused the water contamination? If the energy company caused the contamination, it should bear the burden to show it was not at fault (e.g., that it could not have avoided the problem by taking reasonable precautions). In combination, these three liability rules would encourage firms to comply with best practices regulations, while also motivating them to help develop new best practices regulations covering novel water contamination risks. We would augment these incentives further by eliminating punitive damages for any firm that complies with all best practices regulations.

Since determinations of causation are critical under any liability system, we recommend information-forcing rules to facilitate more accurate determinations of causation. For example, we would require energy companies to test water quality before they begin fracturing and to disclose the chemicals in their fracturing fluid. We also suggest a number of other design features for a liability system, including one-way fee shifting, and provisions to ensure that defendants will not be judgment proof.

To ensure that the regulatory regime is both dynamic and tailored to local conditions, we recommend keeping the regulatory center of gravity in the states, instead of fashioning a new federal regime. All states with oil and gas production have regulatory commissions that impose best practices regulations. ${ }^{6}$ As a result, the states have a head start in developing best practices regulations, and are moving rapidly to adopt additional regulations focused on fracturing. Likewise, state regulators can take account of variations in local conditions. Fracturing differs from one shale field to another, as do water supplies, exposed populations, and the best ways to handle waste. ${ }^{7}$ State regulation is also likely to be dynamic. Because state regulators observe each other, successful regulatory initiatives are likely to disseminate from one state to another. A federal regime, in

6. See, e.g., NORTH DAKOTA INDUSTRIAL COMMISSION DEPARTMENT OF MINERAL RESOURCES, OIL AND GAS DIVISION, https://www.dmr.nd.gov/oilgas/ (last visited Oct. 17, 2013).

7. See Kara Cheever, States' Varied Approaches to Fracking Regulation, REGBLOG (July 24, 2013), https://www.law.upenn.edu/blogs/regblog/2013/07/24 -cheever-state-fracking.html. 
contrast, would have to be developed from scratch after lengthy and contested rulemaking proceedings. It might impose uniform rules that do not always fit local conditions, and that could be harder to change once in place.

Part I offers a brief description of fracturing. Part II summarizes the economic, national security, and environmental benefits of this practice. Part III surveys a number of risks that are not unique to fracturing. Part IV considers the risks to groundwater. Part V offers a general framework for choosing a regulatory strategy, and uses it to recommend a combination of best practices regulation and liability. Part VI fleshes out the details of our proposed liability scheme, including: provisions to enhance the accuracy of determinations of causation; the role of best practices regulations in establishing liability; burdenshifting to energy companies in circumstances where there are no applicable best practices regulations; adjustments to liability if plaintiffs contribute to contamination or have signed a release; the proper measure of damages and allocation of attorney's fees; and ways to address the potential insolvency of defendants. Part VII observes that these functional characteristics can be implemented in various ways-at the federal or state level, and by legislatures or courts. The most realistic course of action in the near term, in our view, is to use select legislative amendments augmenting the authority of state regulatory commissions as needed, plus appropriate modifications to the state common law of torts.

\section{HYDRAULIC FRACTURING: A TECHNOLOGICAL LEAP IN DRILLING FOR SHALE OIL AND GAS}

Traditionally, energy companies have drilled only in rock that is permeable, and thus allows oil and gas to flow freely through it. Petroleum engineers have long understood that deposits within permeable rock represent only a fraction of the oil and gas beneath the earth's surface. Far more is contained in shale deposits, which were off limits because shale is not permeable enough for oil and gas to flow out of it. ${ }^{8}$

8. IHS, NATIONAL ECONOMIC CONTRIBUTIONS, supra note 3 , at 12 . The exact amount of unconventional oil reserves remains uncertain, but recent estimates suggest the United States and Canada have a combined 1301.7 billion barrels (bbl) in total technically recoverable unconventional oil, that is, oil which may or may not be economically recoverable at present. In comparison, the proved reserves (oil which can be economically recovered at current prices) for the entire world are assessed at $1354.2 \mathrm{billion} / \mathrm{bbl}$. AMY MYERS JAFFE ET

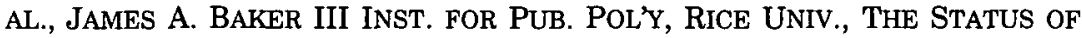


Yet in the past decade, energy companies have learned to tap shale oil and gas reserves, developing new technologies that are commercially feasible at current oil and gas prices. ${ }^{9}$ The key innovation was to pair two technologies which were developed separately: the first is "hydraulic fracturing" or "fracturing," and the second is horizontal drilling. Neither is newfracturing, for instance, was first used in the late 1940s-but the use of both techniques in combination to extract gas from subterranean shale deposits began about ten years ago.

Fracturing involves pumping water into rock at high pressure so the rock cracks ("fractures"), releasing gas and oil trapped inside. The water is mixed with sand or some other "proppant" to prop open the cracks, so they do not reseal and the gas and oil can keep pouring out. ${ }^{11}$ To hold the sand in place, and also to keep bacteria from degrading the gas and oil, other chemicals are added to fracturing fluid as well. Pioneered in the 1940 s as a way to extract greater production from existing wells, this technique was then used in the 1980s to release natural gas from coal beds. ${ }^{12}$ In the past sixty years, over 2 million fracturing treatments have been utilized in connection with oil and gas wells. ${ }^{13}$ An oilman named George Mitchell pioneered the use of fracturing in shale deposits, investing $\$ 6$ million over ten years in the Barnett Shale in Texas. ${ }^{14}$

The key to accessing natural gas and oil in shale is to combine fracturing with horizontal drilling. After drilling down between 6 thousand and 10 thousand feet, energy companies turn

WORLD OIL RESERVES: CONVENTIONAL AND UNCONVENTIONAL RESOURCES IN THE FUTURE SUPPLY MIX 18-19 (2011).

9. See Gas Works: Shale Gas is Giving a Big Boost to America's Economy, ECONOMIST, July 14,2012 , at 5-7 [hereinafter ECONOMIST], available at http://www.economist.com/node/21558459.

10. SeC'y of Energy AdVisory Bd., Shale Gas Production SubcomMITTEE 90-DAY REPORT 8 (2011) [hereinafter FIRST 2011 DOE REPORT], available at http://energy.gov/sites/prod/files/Final_90_day_Report.pdf (pairing hydraulic fracturing with horizontal drilling began in 2002 or 2003 to make shale gas commercially viable).

11. Armando Benincasa, The Current and Future State of Shale Gas and Hydraulic Fracturing Regulation, TRENDS, Jan.-Feb. 2011, at 8.

12. Hannah Wiseman, Untested Waters: The Rise of Hydraulic Fracturing in Oil and Gas Production and the Need to Revisit Regulation, 20 FORDHAM ENVTL. L. REV. 115, 122-23 (2009) [hereinafter Wiseman, Untested Waters].

13. Kevin Fisher, Data Confirm Safety of Well Fracturing, AM. OIL \& GAS REP., July 2010, at 2, available at http://www.halliburton.com/public/pe/ contents/Papers_and_Articles/web/A_through_P/AOGR\%20Article\%20Data\% 20Prove $\% 20$ Safety $\% 20$ of $\% 20 \mathrm{Frac}$.pdf.

14. ECONOMIST, supra note 9, at 8-9. 
the drill sideways. The purpose of drilling horizontally is to increase contact with the layer of shale that has gas or oil in it; this so-called pay zone is sometimes likened to the filling in an Oreo cookie, since it lies between rock layers that have no oil or gas. ${ }^{15}$

The result is a massive new domestic supply of natural gas and oil. ${ }^{16}$ In 2000 , shale supplied negligible amounts of oil and only $2 \%$ of domestically produced natural gas in the U.S. ${ }^{17}$ As recently as 2007 , we were preparing to become a major importer of natural gas. ${ }^{18}$ Yet since 2008 , domestic natural gas production has increased by $25 \% .{ }^{19}$ Today, $37 \%$ of our gas comes from shale; tight sands and shale together account for $50 \%$, with $80 \%$ expected by $2035 .^{20}$ Pennsylvania has the second largest natural gas field in the world, and there are sizable deposits in Arkansas, Louisiana, New York, Ohio, Oklahoma, North Dakota, Texas, and West Virginia. ${ }^{21}$ While natural gas generated $20 \%$ of the nation's electricity in 2006, the percentage has increased to $31 \%$ in just six years. ${ }^{22}$ Of the additional capacity to generate electricity that will be added in the next 25

15. Eric Konigsberg, Kuwait on the Prairie, NEW YoRKER, Apr. 25, 2011, at 45 .

16. In the one-year period from 2009 to 2010 alone, U.S. proved reserves of crude oil increased 12.8\%, from 22.3 billion barrels (bbl) to $25.2 \mathrm{bbl}$, and natural gas proved reserves increased $11.9 \%$, from 283.9 trillion cubic feet (tcf) to 317.6 tcf. U.S. INFO. ADMIN., U.S. CRUDE OIL, NATURAL GAS, AND NATURAL GAS LIQUIDS PROVED RESERVES, 2010 at 1 (2012), available at $\mathrm{http}: / / \mathrm{www}$.eia .gov/naturalgas/crudeoilreserves/archive/2010/pdf/uscrudeoil.pdf. These increases represented the largest one-year additions since the U.S. Energy Information Administration began publishing reserve estimates in 1977, an increase the agency attributed to "the expanding application of horizontal drilling and hydraulic fracturing in shale and other 'tight' formations." Id.

17. IHS GLOBAL INSIGHT, THE ECONOMIC AND EMPLOYMENT CONTRIBUTIONS OF SHALE GAS IN THE UNITED STATES 9 (2011) thereinafter, IHS GLOBAL INSIGHT, 2011 SHALE GAS REPORT], available for download at http://www .ihs.com/info/ecc/a/shale-gas-jobs-report.aspx.

18. FIRST 2011 DOE REPORT, supra note 10, at 7; IHS, NATIONAL ECONOMIC CONTRIBUTIONS, supra note 3 , at 3 .

19. IHS, NATIONAL ECONOMIC CONTRIBUTIONS, supra note 3 , at 3.

20. Id. at 3,15 .

21. Christopher Bateman, A Colossal Fracking Mess, VANITY FAIR (June $21,2010), \mathrm{http}: / / \mathrm{www}$.vanityfair.com/business/features/2010/06/fracking-in -pennsylvania-201006.

22. ECONOMIST, supra note 9; Benoit Faucon \& Keith Johnson, U.S. Redraws World Oil Map, WALL ST. J., Nov. 13, 2012, at A4 (quoting an estimate of International Energy Agency that natural gas will replace oil as the largest single fuel in the energy mix, and noting that natural gas accounted for $31 \%$ of electricity in the first eight months of 2012). 
years, $60 \%$ is expected to come from natural gas. ${ }^{23}$

In addition to natural gas, massive supplies of domestic oil in shale beds have also been unlocked. "The rise in tight oil production in the United States in the past few years," the IEA observed in November 2012, "has been nothing short of spectacular. ${ }^{24}$ While only 100,000 barrels per day (bpd) of oil were produced from shale in 2003, 2 million bpd were produced in 2012 , and the level is expected to rise to 4.5 million bpd in the coming years. ${ }^{25}$ While U.S. oil production had been in steep decline for decades, we experienced a 2.735 million bpd net increase in production from 2008 to the first four months of 2013 , representing a $40 \%$ increase. ${ }^{26}$ Production increased by a record 1 million bpd in 2012 alone. ${ }^{27}$ Notably, the Bakken Shale in North Dakota is a 25,000 square mile sheet of embedded oil. It is estimated to have 11 billion barrels of oil recoverable with current technology, an estimate that keeps increasing; the ultimate number may be as much as 30 billion barrels. ${ }^{28}$ Although North Dakota was producing less than one percent of the nation's oil as recently as $2008,{ }^{29}$ it passed California and Alas$\mathrm{ka}$ in 2012 to become the second largest oil producing state in the U.S. after Texas (where production is also surging). ${ }^{30} \mathrm{By}$ 2020 , the U.S. is expected to produce 11.1 million barrels a day,

23. IHS GLOBAL INSIGHT, 2011 SHALE GAS REPORT, supra note 17 , at $\mathbf{1 3}$ (forecasting the addition of 481 gigawatts between 2010 and 2035, and projecting that $60 \%$ would be generated with natural gas).

24. IEA, WORLD ENERGY OUTLOOK 2012, supra note 2, at 108.

25. IHS, NATIONAL ECONOMIC CONTRIBUTIONS, supra note 3, at 5, 17.

26. U.S. production was 6.784 million bpd in 2008, and the average for the first four months of 2013 was 9.519 million bpd. U.S. ENERGY INFO. ADMIN., MONTHLY ENERGY REVIEW 37 (May 2013), available at http://www.eia.gov/ totalenergy/data/monthly/archive/00351305.pdf.

27. BP, STATISTICAL REVIEW OF WORLD ENERGY JUNE 2013 at 8 (2013), available at http://www.bp.com/content/dam/bp/pdf/statistical_review_of_ world_energy_2013.pdf (production increased from approximately 7.9 bp $\bar{d}$ to $8.9 \mathrm{bpd}$ in 2012).

28. Konigsberg, supra note 15 , at $43-44,52$; see also, e.g., USGS, ASSESSMENT OF UNDISCOVERED OIL RESOURCES IN THE BAKKEN AND THREE FORKS Formations, Williston Basin PROVINCE, MONTANA, NorTh Dakota, aND SOUTH DAKOTA (2013), available at http://pubs.usgs.gov/fs/2013/3013/fs2013 -3013.pdf (estimating 7.4 billion barrels of technically recoverable oil in the Bakken and Three Forks formations).

29. James MacPherson, North Dakota Oil Production Forecast to Surpass Alaska's, ANCHORAGE DAILY NEWS, Jan. 2, 2011, http://www.adn.com/2011/01/ 02/1629025/north-dakota-oil-production-is.html.

30. Russell Gold, Oil and Gas Bubble Up All Over, WaLl ST. J., Jan. 3, 2012, at A7 (noting the Bakken oil field produced 424,000 bpd in July 2011, compared with 453,000 per day from Prudhoe Bay in Alaska). 
which will be more than Saudi Arabia. ${ }^{31}$

There is some question about the staying power of these new natural gas and oil reserves. ${ }^{32}$ For instance, drilling costs for shale oil are high, so a global decline in prices could cause companies to reduce production. ${ }^{33}$ In addition, some experts caution that fractured wells may not produce as long as conventional wells. ${ }^{34}$ Even so, estimates of recoverable reserves have generally been increasing over time ${ }^{35}$ It may well be, as President Obama suggested in his 2012 State of the Union Address, that fracturing will generate 100 years of natural gas supply for the United States at our current rate of consumption.

31. IEA, WORLD ENERGY OUTLOOK 2012, supra note 2, at 107 (projecting $11.1 \mathrm{mb} / \mathrm{d}$ in US in 2020); id. at 115 (projecting $10.6 \mathrm{mb} / \mathrm{d}$ in Saudi Arabia in 2020); Faucon \& Johnson, supra note 22, at 1 (quoting estimate of International Energy Agency).

32. See James Stafford, Shale Gas Will Be the Next Bubble to Pop: An In. terview With Art Berman, OILPRICE.COM (Nov. 12, 2012, 11:11 PM), http:// oilprice.com/Interviews/Shale-Gas-Will-be-the-Next-Bubble-to-Pop-An

-Interview-with-Arthur-Berman.html (noting that decline rates in shale plays are high and that shale gas has not been profitable).

33. Indeed, in 2012 U.S. natural gas prices fell below the marginal cost of drilling (approximately $\$ 5.00$ per MBtu), so that energy companies focused instead on oil or on so-called wet gas (i.e., natural gas wells that also provide more-profitable natural gas liquids). U.S. ENERGY INFO. ADMIN., NATURAL GAS WEEKLY UPDATE (2013), available at http:/www.eia.gov/naturalgas/ weekly/archive/2013/09_05/index.cfm. Yet prices subsequently rose in 2013. See Id. Indeed, if demand increases from exports, new dry gas wells could become profitable again. See IEA, WORLD ENERGY OUTLOOK 2012, supra note 2, at $143-44$.

34. Henry D. Jacoby et al., The Influence of Shale Gas on U.S. Energy and Environmental Policy, 1 ECON. OF ENERGY \& ENVTL. POL'Y 37, 39-40 (2012) (noting that shale wells experience steep production declines, but that these declines have been taken into account in estimates of proven reserves).

35. PricewaterhouseCoOPERS, Shale Gas: A RENAISSANCE IN US MANUFACTURING? 2 (2011), http://www.pwc.com/en_US/us/industrial -products/assets/pwc-shale-gas-us-manufacturing-renaissance.pdf; 2011 MIT STUDY, supra note 4, at 7 ("Assessments of the recoverable volumes of shale gas in the U.S. have increased dramatically over the last five years, and continue to grow.").

36. President Barack Obama, 2012 State of the Union Address (Jan. 24, 2012) (transcript available at http://articles.washingtonpost.com/2012-01-24/ politics/35440939_1_fair-share-hard-work-world-war-ii). An MIT study estimates ninety-two years of supply (assuming continuation of the 2009 level of gas consumption), and notes that this represents a $77 \%$ increase in estimates of remaining gas resources since 1990. 2011 MIT STUDY, supra note 4, at 30, 32. $C$ f. KenNeth B. Medlock III ET al., JAMES A. BAKER III INST. FOR PUB. POL'Y AT RICE UNTV., SHALE GAS AND NATIONAL SECURITY 5 (2011), available at http///www.bakerinstitute.org/publications/EF-pub-DOEShaleGas -07192011.pdf (estimating 45 years of technically recoverable natural gas). 


\section{ECONOMIC, NATIONAL SECURITY, AND ENVIRONMENTAL BENEFITS FROM FRACTURING}

\section{A. ECONOMIC GROWTH}

The benefits from this new supply of energy for our economy, security, and environment are enormous. A cheap domestic supply of energy is a powerful engine of economic growth. ${ }^{37}$ Shale oil and gas are capital-intensive and high-paying industries, generating $\$ 87$ billion of capital investments in the U.S. 2012 . They are expected to generate $\$ 172.5$ billion of investment annually by the end of the decade and $\$ 5.1$ trillion in total by $2035 .^{38}$ Every drilling job is estimated to create three to four other jobs (e.g., among suppliers of machinery, geological surveys, and financial services), a so-called employment multiplier that compares favorably with other industries. ${ }^{39}$ Not surprisingly, then, North Dakota has the lowest unemployment rate in the nation, which is less than half the national rate. ${ }^{40} \mathrm{In}$ Pennsylvania, counties with more than 200 wells added jobs at a 7\% annual rate between 2007 and 2011 , compared with a $3 \%$ annual decline during the same period in counties with few or no wells. ${ }^{41}$ Nor are economic growth and job creation confined to

37. See IHS, NATIONAL ECONOMIC ConTRIBUTIONS, supra note 3 at 2.

38. Id. at 2, 6-7 (projecting $\$ 2.1$ trillion of capital investment for unconventional oil and $\$ 3$ trillion for unconventional natural gas between 2012 and 2035 and noting that supply chains for industry are principally domestic); $i d$. at 28 (noting that average hourly wage in unconventional oil and gas, $\$ 51.00$ per hour, is more than double average wage in economy overall, \$23.07).

39. Id. at 2, 31 (noting that jobs from drilling represent only $20 \%$ of total jobs created and that employment multiplier is high compared with other industries); IHS GLOBAL INSIGHT, 2011 SHALE GAS REPORT, supra note 17, at 17,21 (noting that shale gas industries employment multiplier of three is "one of the larger employment multipliers," ahead of "finance, construction, and many of the manufacturing sectors"; further noting that drilling is also highpaying); GREG JANSEN \& ETHAN LEVINE, COMMONFUND CAPITAL, BEHIND THE ENERGY RENAISSANCE IN THE UNITED STATES 39 (2012), available at http:// www.commonfund.org/InvestorResources/Publications/INSIGHT\%20Articles\% 200nly/Insight_Fall2012_Jansen.pdf (long supply chains and high pay in industry contribute to employment multiplier). One journalist reported that oil industry workers in North Dakota can earn over $\$ 70,000$ in five months, and that their supervisors earn $\$ 320,000$ in a year. Konigsberg, supra note 15 , at 50 .

40. North Dakota Unemployment, DEPARTMENT OF NUMBERS, http://www .deptofnumbers.com/unemployment/north-dakota/ (last visited Oct. 17, 2013) (noting that in December 2012, North Dakota's unemployment rate was 3.2\%, while the national rate was $7.8 \%$ ).

41. DiANA FurchtgotT-Roth \& ANDREW GRAY, EMPIRE CTR. FOR N.Y. STATE POL'Y, THE ECONOMIC EFFECTS OF HYDROFRACTURING ON LOCAL 
oil and gas producing states, since supply chains extend to other states as well. ${ }^{42}$ According to IHS Global Insight, shale oil and gas supported 1.7 million U.S. jobs in 2012; this number is expected to increase to 3 million in 2020 , representing $2 \%$ of total employment in the U.S. ${ }^{43}$ Obviously, this is a significant boon to an economy that shed 7 million jobs in the wake of the 2008 financial crisis and has created jobs haltingly in the five years since. ${ }^{44}$

Fracturing in shale beds can also enhance the purchasing power of landowners. The media has reported that North Dakota landowners generally earn a bonus royalty of $\$ 3,000$ per acre plus a $20 \%$ stake in any oil that is produced. This means that a "moderately productive plot of two square miles could bring the owners - typically, groups of relatives and speculators- a million dollars up front, and five hundred thousand dollars a year for two decades." ${ }^{45}$

Even more important, though, is the impact on consumers. The shale gas boom has caused natural gas prices to plummet to between one-third and one-half of their 2008 level. ${ }^{46}$ By contrast, natural gas prices are four to eight times higher in Europe and Asia, which gives a sense of what U.S. prices would be if set by gas imports, instead of by domestically produced shale gas. ${ }^{47}$ This savings ripples throughout the economy, since over

ECONOMIES: A COMPARISON OF NEW YORK AND PENNSYLVANIA 2 (2013), available at http://www.empirecenter.org/Reports/2013/05/econeffectfracking 050613.cfm.

42. See generally IHS GLOBAL INSIGHT, AMERICA'S NEW ENERGy FutURE: THE UNCONVENTIONAL OIL AND GAS REVOLUTION AND THE U.S. ECONOMY: STATE ECONOMIC CONTRIBUTIONS (2012).

43. IHS, NATIONAL ECONOMIC CONTRIBUTIONS, supra note 3 , at 2, 7-8, 27-28.

44. Jeffrey Bartash, U.S. Job Growth Better, But Is it Good?, MARKETWATCH (Aug. 9, 2013), http://www.marketwatch.com/story/us-job -growth-is-better-but-is-it-good-2013-08-09.

45. Konigsberg, supra note 15 , at 51.

46. U.S. Natural Gas Wellhead Price, U.S. ENERGY INFORMATION ADMINISTRATION, http://www.eia.gov/dnav/ng/hist/n9190us $3 \mathrm{~m} . \mathrm{htm}$ (last updated Aug. 30, 2013) (declining from $\$ 10.36$ in June 2008 to $\$ 2.54$ in June of 2012 , with prices stated in dollars per thousand cubic feet). Prices rebounded to approximately $\$ 3.00$ in the fall of 2012. See Liam Pleven, What Glut? Gas Prices Rise, WALL ST. J., Sept. 28, 2012, at C4, and to approximately $\$ 4.00$ in the spring of 2013; Natural Gas Weekly Update, U.S. ENERGY INFORMATION ADMINISTRATION, http://www.eia.gov/naturalgas/weekly/ (last updated Aug. 29. 2013).

47. IEA, WORLD ENERGY OUTLOOK 2012, supra note 2, at 129 (finding gas prices in June 2012 were $\$ 2.10$ per MBtu in the United States, $\$ 9.90 / \mathrm{MBtu}$ in the United Kingdom, \$12/MBtu for liquid natural gas in the Mediterranean 
half of U.S. energy consumption is for heating and electricity in residential and commercial buildings. ${ }^{48}$ The savings averages $\$ 926$ per year for every American household ${ }^{49}$-almost $2 \%$ of the U.S. median household income ${ }^{50}$-and is expected to grow to $\$ 2,000$ in $2035 .{ }^{51}$

Since every business spends on energy, this savings also hits the bottom line of U.S. businesses, enabling them to cut costs, increase profits, and hire more people. ${ }^{52}$ Reductions in natural gas prices, for instance, are expected to reduce electricity prices by $10 \%$, and to trigger a $2.9 \%$ increase in industrial production by 2017 , and a $4.7 \%$ increase by $20355^{53}$ The most significant impact is on energy-intensive industries such as glass, steel, cement, aluminum and, especially, the petrochemicals industry. ${ }^{54}$ The latter also uses chemicals in natural gas, such as ethane, as raw material for its products. In response to declining U.S. natural gas prices, Methanex is moving a plant from Chile to Louisiana, ${ }_{55}$ and Dow Chemical, Chevron Phillips Chemical, and Exxon Mobil have also announced new investments in the United States. ${ }^{56}$ An Egyptian company is building a fertilizer plant in Iowa, making the largest investment in the state's history. ${ }^{57}$ Industry analysts project that lower petrochemical and energy costs will yield one million more manufac-

and $\$ 17.40 / \mathrm{MBtu}$ in northeast Asia); see also JANSEN \& LEVINE, supra note 39, at 39 (finding U.S. natural gas prices are lowest in the world).

48. See 2011 MIT STUDY, supra note 4, at 4 (49.2 out of 94.6 quads).

49. IHS GLOBAL INSIGHT, 2011 SHALE GAS REPORT, supra note 17 , at 26 .

50. According to the U.S. Census Bureau, the 2011 median household income in the United States was \$50,054. Median Household Income by StateSingle-Year Estimates, U.S. CENSUS BUREAU, http://www.census.gov/hhes/ www/income/data/statemedian/ (last visited Sept. 26, 2013).

51. IHS GLOBAL INSIGHT, 2011 SHALE GAS REPORT, supra note 17, at 26 (estimating savings of $\$ 926$ per household from $2012-15$, growing to $\$ 2000$ per household in 2035).

52. See id.

53. Id. at 36 .

54. Id. at $4,11$.

55. Methanex Corp to Move Chile Plant to Louisiana, REUTERS (Apr. 25, 2013), http://in.reuters.com/article/2013/04/25/methanex-plant-idINL2NODC17 J20130425.

56. IHS GLOBAL INSIGHT, 2011 Shale GaS REPORT, supra note 17, at 2, $28-31$.

57. Ahmed A. Namatalla \& Nadine Marroushi, Egypt's OCI to Build $\$ 1.4$ Billion Fertilizer Plant in Iowa, BLOOMBERG NEws (Sept. 5, 2012), http://www .bloomberg.com/news/2012-09-05/egypt-s-oci-to-build-1-dot-4-billion-fertilizer -plant-in-iowa ("Orascom Construction Industries (OCIC), Egypt's biggest publicly traded company, said it will build a $\$ 1.4$-billion fertilizer plant in Iowa, the biggest investment in the state's history."). 
turing jobs in the United States by 2025 , adding $.5 \%$ annual growth to gross domestic product. ${ }^{5}$

Since almost one-third of U.S. energy consumption is for transportation, cheap natural gas can have even greater impact over the long term by replacing petroleum for cars, trucks, and buses. ${ }^{59}$ It is possible to power vehicles with natural gas, and natural gas now costs less than a fifth of the cost of oil on an energy-equivalent basis, creating a powerful economic incentive to substitute natural gas for oil. ${ }^{60}$ Today, filling stations and other infrastructure are overwhelmingly focused on petroleum. ${ }^{61}$ This is less of an issue, though, for buses, garbage trucks, and other municipal vehicles, which have their own refueling facilities. ${ }^{62}$ As a result, an increasing number of companies and municipalities are buying natural-gas-powered buses and trucks. ${ }^{63}$ The economics of powering long-haul trucks with natural gas are especially compelling. Electric cars and plug-in hybrids can also be powered by electricity generated with natural gas, and there are chemical processes to convert natural gas into a liquid fuel as well. ${ }^{64}$ If the enormous price differential between natural gas and petroleum persists, entrepreneurs will figure out how to supply natural gas as a fuel for ordinary cars and trucks. ${ }^{65}$

58. PRICEWATERHOUSECOOPERS, supra note 35 , at 1 (estimating one million additional jobs due to affordable energy and demand for products to extract shale gas); DAVID P. MURPHY, OUTLOOK NORTH AMERICAN ENERGY INDEPENDENCE, REENERGIZED (2012), available at http://americanpetproducts .org/Uploads/MemServices/UBS_SummerOutlookJuly2012.pdf (noting that UBS economists forecast that the U.S. energy boom is contributing additional $.5 \%$ annual GDP growth). But see Nelson D. Schwartz, Manufacturing's Mirage: A Jobs Boom Built on Cheap Energy Has Yet to Appear, N.Y. TIMES, Apr. 2,2013 , at B1-B2 (cautioning that widespread automation may temper job creation associated with a manufacturing rebound driven by cheap energy).

59. See 2011 MIT STUDY, supra note 4, at 4, 99.

60. See MURPHY, supra note 58.

61. Cf. 2011 MIT Study, supra note 4, at 121 ('Use of CNG requires a new fueling infrastructure ....").

62. See id. at 11 ("[I]nfrastructure issues do not impede development."). See generally CALEY JOHNSON, NAT'L RESEARCH COUNCIL, BUSINESS CASE FOR COMPRESSED NATURAL GAS IN MUNICIPAL FLEETS, NREL TECHNICAL REPORT NREL/TP-7A247919 (2010), available at http://www.afdc.energy.gov/ pdfs/47919.pdf (offering a model to project profitability of CNG use for fleets such as buses and trucks).

63. Michael Rubinkam, Natural Gas Drillers Target US Truck, Bus Market YAHOO FINANCE (Nov. 25, 2012, 3:12 PM), http://finance.yahoo.com/news/ natural-gas-drillers-target-us-truck-bus-market-182633169-finance.html.

64. See 2011 MIT STUDY, supra note 4, at 4, 125-28.

65. Cf. id. at 123 . 
All of these economic benefits will be reflected in our balance of payments. The 2012 current accounts deficit of the United States was estimated to be $\$ 695$ billion, ${ }^{66}$ which included $\$ 319$ billion of oil imports. If not for the increase in shale oil and gas production since 2008 , the deficit would have been almost 25\% larger (reflecting an additional $\$ 70$ billion of oil and $\$ 100$ billion of natural gas for a total of $\$ 865$ billion). ${ }^{67}$ If domestic oil production increases as expected, the deficit will be reduced further by $\$ 185$ billion (or $27 \%$ ) over the coming years ${ }^{68}$-and by more if we export significant amounts of natural gas.

Through the combination of all these effects, shale oil and gas contributed over $\$ 237$ billion to U.S. GDP in 2012 , and is expected to contribute $\$ 416$ billion in 2020 and $\$ 475$ billion in $2035 .^{69}$ Likewise, shale oil and gas contributed nearly $\$ 62$ billion in federal, state and local tax revenue in 2012, a level that is projected to grow to $\$ 111$ billion in 2020 , for a total of nearly $\$ 2.5$ trillion over the next quarter century. ${ }^{30}$

\section{B. ENERGY INDEPENDENCE AND NATIONAL SECURITY}

Reducing our dependence on imported energy has geopolitical advantages as well. ${ }^{71}$ Some of the world's leading oil and natural gas exporters are either unstable or hostile to the United States or both. The top eight oil-exporting nations to the world market are Saudi Arabia, Russia, Iran, the United Arab Emirates, Norway, Iraq, Angola, and Nigeria. ${ }^{72}$ Likewise, $70 \%$ of the world's conventional gas reserves (i.e., not including shale gas) are in Iran, Qatar, and Russia. ${ }^{73}$ Some of these regimes consistently seek to undermine U.S. foreign policy goals, and added oil and gas revenue strengthens their ability to do

66. IHS, NATIONAL ECONOMIC CONTRIBUTIONS, supra note 3, at 5.

67. Id. at 3,5 .

68. Id. at 6 (assuming a reduction of 6 million barrels per day of imports at $\$ 112$ per barrel, the average price per barrel during the first nine months of 2012).

69. Id. at 8.

70. Id. at 2,8 .

71. John Bussey, Shale: A New Kingmaker in Energy Geopolitics, WaLL ST. J., Sept. 21, 2012, at B1 ("Had it not been for this growth in U.S. production, the sanctions on Iran could not have been as successful . . ..") (quoting Daniel Yergin).

72. The World Factbook, CENT. INTELLIGENCE AGENCY, https://www.cia .gov/library/publications/the-world-factbook/rankorder/2176rank.html (last visited Oct. 17, 2013).

73. 2011 MIT STUDY, supra note 4, at 7. 
so. ${ }^{74}$ Indeed, in some cases, these resources may fund terrorist networks that target the U.S. and our allies. ${ }^{75}$ Recent events in the Middle East-the nuclear program in Iran, the attack on the U.S. Embassy in Libya, the seizure of hostages by terrorists at a natural gas facility in Algeria, etc.-suggest that, if anything, the Middle East is becoming more unstable and hostile to the U.S.

It is fortunate, then, that the U.S. has gone from importing $60.3 \%$ of its oil (on a net basis) in 2005 to $36.2 \%$ in early 2013 , with further reductions in U.S. oil imports expected in the next two decades. ${ }^{76}$ In fact, the IEA projects the U.S. to be $97 \%$ energy self-sufficient in net terms by $2035 .^{77}$ The increase in U.S. oil production since 2008 is more than what Iran was exporting before sanctions were imposed, a fact that has made those sanctions more viable. ${ }^{78}$ Likewise, if Europe starts to buy natural gas from the U.S. and other sources instead of Russia, Russia will have less leverage over Europe. ${ }^{79}$ Meanwhile, China has shale gas reserves that may be larger than those in the U.S. (as well as significant reserves of shale oil), and ultimately may also depend less on the Middle East and other traditional energy

74. See John Hannah, Energy Insecurity: How Oil Dependence Undermines America's Effort to Stop the Iranian Bomb, FOREIGN POL'Y, Oct. 12, 2012, http://shadow.foreignpolicy.com/posts/2012/10/12/energy_insecurity how_oil_dependence_undermines_america_s_effort_to_stop_the_irania.

75. See Kevin J. Fandl, Terrorism, Development \& Trade: Winning the War on Terror Without the War, 19 AM. U. INT'L L. REv. 587, 614 (2003).

76. IEA, WORLD ENERGY OUTLOOK 2012, supra note 2, at 120 (predicting that US oil imports fall from over $12 \mathrm{mb} / \mathrm{d}$ in 2005 to $3.4 \mathrm{mb} / \mathrm{d}$ in 2035 , and "North America as a whole becomes a net exporting region"); Elisabeth Rosenthal, U.S. Is Forecast to Be No. 1 Oil Producer, N.Y. TIMES, Nov. 13, 2012, at B6; U.S. ENERGY INFO. ADMIN., supra note 26, at 41.

77. IEA, WORLD ENERGY OUTLOOK 2012, supra note 2, at 75 (projecting US to be "97\% energy self-sufficient in net terms" by 2035 , as exports of coal, gas, and bioenergy offset declining oil imports).

78. Daniel Yergin, The Real Stimulus: Low Cost Natural Gas, WALL ST. J., Oct. 23, 2012, at A17 ("Without the additional oil coming from the surge in U.S. oil output, the Iranian oil sanctions could not have worked as well as they have."); see also MEDLOCK ET AL., supra note 36, at 13 (tapping domestic shale gas reserves "[r]educes Iran's ability to tap energy diplomacy as a means to strengthen its regional power or buttress its nuclear aspirations"). U.S. oil production increased by 2.735 million bpd from 2008 through the first four months of 2013. See U.S. ENERGY INFO. ADMIN. supra note 26. By contrast, Iran was producing 4.396 million bpd in 2008 and consuming 1.906 million bpd, leaving a net of 2.490 for export. See BP STATISTICAL REVIEW OF WORLD ENERGY 8-9 (2012), available at http://www.bp.com/liveassets/bp_internet/ globalbp/globalbp_uk_english/reports_and_publications/statistical_energy _ review_2011/STAGING/local_assets/pdf/oil_section_2012.pdf.

79. MEDLOCK ET AL., supra note 36, at 54 . 
suppliers. ${ }^{80}$ The United Kingdom recently doubled its estimate of its shale gas reserves, and Argentina, Canada, Mexico, Australia, and other nations have significant reserves of shale oil and gas as well. ${ }^{81}$ This greater diversity of energy supply is sure to have geopolitical consequences.

For example, developing U.S. and other shale oil and gas resources may enable the U.S. to cut its defense budget and even to reduce the probability of future terrorist attacks and wars. The U.S. spends $\$ 60$ to $\$ 80$ billion every year to police the sea lanes from the Middle East, but as we import less oil, we may be able to spend less. ${ }^{82}$ Admittedly, the U.S. remains exposed to price shocks in the oil market, even with domestically produced oil (since prices are based on global, rather than local, market conditions). ${ }^{83}$ Putting the need for energy aside, moreover, there are other reasons why the U.S. has been, and will remain, engaged in the Middle East, including the value of averting instability and its associated costs. ${ }^{84}$ Yet even so, there

80. Elizabeth Muller, China Must Exploit its Shale Gas, N.Y. TIMES, Apr. 13,2013 , at A21 ("China has the potential to unearth large amounts of shale gas through hydraulic fracturing. In 2011, the United States Energy Information Administration estimated that China had 'technically recoverable' reserves of 1.3 quadrillion cubic feet, nearly 50 percent more than the United States."). In July of 2013, PetroChina entered into an agreement with Hess to begin developing a shale oil field in northwest China. Chen Aizhu \& Judy Hua, Hess, PetroChina Sign China's First Shale Oil Deal, REUTERS (July 24, 2013), http://www.reuters.com/article/2013/07/24/us-cnpc-hess-shale-idUSBRE 96N0EL20130724.

81. Sarah Young \& John McGarrity, Update 2-Britain Doubles North England Shale Gas Estimate, REUTERS, June 27, 2013, http://uk.reuters.com/ article/2013/06/27/uk-britain-shale-resources-idUKBRE95Q0CD20130627;

U.S. ENERGY INFO. ADMIN., Technically Recoverable Shale Oil and Shale Gas Resources: An Assessment of 137 Shale Formations in 41 Countries Outside the United States (2013), available at http://www.eia.gov/analysis/studies/ worldshalegas/ (listing nations with most shale oil and shale gas reserves); see Press Release, UK Dep't of Energy \& Climate Change, Estimates of Shale Gas Resource in North of England Published, Alongside a Package of Community Benefits (June 27, 2013), available at https://www.gov.uk/government/news/ estimates-of-shale-gas-resource-in-north-of-england-published-alongside-a -package-of-community-benefits ("Scientists from the British Geological Survey have estimated on a central scenario that there is likely to be some 40 trillion cubic metres (1,300 trillion cubic feet) of shale gas in the ground in this area.").

82. Faucon \& Johnson, supra note 22, at A4 (quoting prediction of International Energy Agency).

83. Id.

84. Indeed, if a collapse in oil prices destabilizes the region, this would create a number of challenges for the U.S. and its allies. See, e.g., Charles C. Mann, What if We Never Run Out of Oil?, ATLANTIC MONTHLY, May 2013, at 48,61 (describing an "arc of instability stretching from Venezuela to Nigeria to 
are obvious advantages to energy independence, which explain why every President in recent memory has championed this goal. ${ }^{85}$ While it has not seemed attainable for decades, the energy reserves in U.S. shale beds have changed the equation.

\section{ENVIRONMENTAL BENEFITS: AIR QUALITY AND CLIMATE CHANGE}

\section{Cleaner Air from Using Gas Instead of Coal}

Although this Article's focus is on regulating potential environmental risks from fracturing, there are two potentially significant environmental benefits as well. The first is cleaner air, an indisputable benefit of replacing coal with natural gas. Coal pollutes the air with particulate matter, sulphur dioxide, and carbon monoxide, producing pea-soup like air (which can be found, for instance, in Chinese cities), as well as attendant health effects. ${ }^{86}$ By contrast, natural gas burns much cleaner than coal. ${ }^{87}$ Until recently, coal generated almost half of the electricity in the United States, but declining natural gas prices have led power plants to switch to gas; as a result, the level of coal-generated electricity declined to $42 \%$ in 2011 and $36 \%$ in 2012 , the lowest levels since these numbers were first tracked in $1949 .^{88}$

Saudi Arabia to Kazakhstan to Siberia"). But see Holman W. Jenkins, Jr., Why the Energy Mopes Are Wrong, WALL ST. J., May 4, 2013, at A15 (arguing that prices are unlikely to fall to the extent that they would destabilize these regimes, and emphasizing the geopolitical advantages of reducing the coercive capacity of petrostates).

85. See MichaEL J. GraetZ, The END OF ENERGY, 260-61 (2011) (describing the importance of energy security).

86. Jeff Blagdon, China's Air Pollution Led to 1.2 Million Premature Deaths in 2010, THE VERGE (Apr. 3, 2013, 1:22 AM), http://www.theverge.com/ 2013/4/3/4177568/china-air-pollution-causes-1-2-million-premature-deaths; see also, e.g., Yuyu Chen et al., Evidence on the Impact of Sustained Exposure to Air Pollution on Life Expectancy from China's Huai River Policy, 110 PROC. NAT'L ACAD. SCI., 12,936, 12,936 (2013); Anthony Seaton, William Macnee, Kenneth Donaldson \& David Godden, Particulate Air Pollution and Acute Health Effects, 345 THE LANCET 176, 176 (1995) (describing health effects from coal pollution); Richard Silk, Coal Pollution Cuts Life Expectancy in China, Study Finds, WALL ST. J., July 9, 2013, at A14 (life expectancy cut by more than five years in 1990's).

87. 2011 MIT STUDY, supra note 4, at 3 ("Among the fossil fuels . . [natural gas] burns cleanly and efficiently, with very few non-carbon emissions.").

88. ECONOMIST, supra note 9, at 6 . 


\section{Climate Change: Reduced Greenhouse Gas Emissions from Burning Gas Instead of Coal}

A second (more contested) environmental benefit from fracturing-and, in particular, from replacing coal with natural gas-is the potential to reduce carbon dioxide emissions, and thus to combat climate change. Burning natural gas produces only half as much carbon dioxide as coal. ${ }^{89}$ This shift from coal to natural gas is a key reason why U.S. carbon dioxide emissions declined by $12 \%$ from 2005 to 2012 (including a $3.8 \%$ decline in 2012 alone), and are at their lowest level since $1994 .^{90}$ This decline is the largest anywhere in the world, and occurred during a period when global emissions rose by $8 \%$. China's emissions have risen dramatically as they have built more coalfired power plants. ${ }^{91}$ Likewise, Europe has made less progress than the U.S.-notwithstanding its stricter regulations of greenhouse gas emissions-because natural gas is more expensive there, so that Europe has been increasing its use of coal. ${ }^{92}$

Going forward, by making greater use of natural gas to generate electric power, we can reduce U.S. greenhouse gas emissions from this sector by $20 \%$, or $8 \%$ overall, according to a 2011 MIT study. ${ }^{93}$ We can make even more progress by using more natural gas to power industry, home heating, and trans-

89. Benincasa, supra note 11, at 8; see also 2011 MIT STUDY, supra note 4, at 3 ("Among the fossil fuels, [natural gas] has the lowest carbon intensity, emitting less $\mathrm{CO} 2$ per unit of energy generated than other fossil fuels. It burns cleanly and efficiently, with very few non-carbon emissions."); id. at 121 (natural gas also burns cleaner than oil, producing $25 \%$ less $\mathrm{CO} 2$ compared to gasoline). For numerical estimates of the difference between coal and natural gas on a lifecycle basis, see the studies cited infra notes $91 \& 97$.

90. Russell Gold, Rise in U.S. Gas Production Fuels Unexpected Plunge in Emissions, WALL ST. J., Apr. 19, 2013, at A1 (citing study by the Energy Information Administration); Trevor Houser, Neck and Neck: US and European GHG Emissions Trends, RHODIUM GROUP (May 29, 2013), http://rhg.com/ notes/neck-and-neck-us-and-european-ghg-emissions-trends.

91. See Muller, supra note 80 ("China's greenhouse gas emissions are twice those of the United States and growing at 8 percent to 10 percent per year. Last year, China increased its coal-fired generating capacity by 50 gigawatts, enough to power a city that uses seven times the energy of New York City.").

92. Brad Plumer, How Long Before Fracking Spreads to Europe? A Decade, at Least, WASH. POST. WONKBLOG (Feb. 7, 2013, 11:10 AM), http://www .washingtonpost.com/blogs/wonkblog/wp/20B/02/07/will-fracking-ever-spread -to-europe-maybe-in-a-decade.

93. 2011 MIT STUDY, supra note 4, at 2; see also id. at 9 ("Displacement of coal-fired power by gas-fired power over the next 25 to 30 years is the most cost-effective way of reducing $\mathrm{CO} 2$ emissions in the power sector."). 
portation. ${ }^{94}$ Fracturing thus facilitates the use of natural gas as a bridge fuel, reducing carbon emissions in the near term, while solar and other renewable technologies are developed over the long term. ${ }^{95}$ We also avoid the risks of nuclear power, demonstrated at Chernobyl and Fukushima.

\section{Climate Change: Offsetting Effects of Fugitive Methane} Emissions

A caveat about greenhouse gas emissions is in order, though. Although burning methane (the main ingredient in natural gas) releases comparatively small amounts of $\mathrm{CO}_{2}$, releasing methane into the atmosphere-for instance, during drilling or from pipeline leaks-is a potentially significant source of greenhouse gas emissions. In fact, methane traps twenty times more heat than carbon dioxide ${ }^{96}$ Focusing on these fugitive emissions, Robert Howarth has argued that shifting from coal to natural gas actually does not reduce greenhouse gas emissions when measured on a "lifecycle" basis."

Yet this conclusion is not widely accepted. ${ }^{98}$ A number of studies reach more favorable conclusions. They argue that Professor Howarth's analysis is plagued by measurement and methodological errors, such as failing to distinguish between methane that is "vented" (deliberately leaked during drilling) or "flared" (burned during drilling). ${ }^{99}$ The debate is ongoing,

94. Id. at $10-11$.

95. Id. at 2 ("[N]atural gas provides a cost-effective bridge to . . . a lowcarbon future.").

96. EPA, INVENTORY OF U.S. GREENHOUSE GAS EMISSIONS AND SINKS, at ES-12 (2013).

97. See Robert W. Howarth, Renee Santoro \& Anthony Ingraffea, Methane and the Greenhouse-Gas Footprint of Natural Gas from Shale Formations, a Letter, 106 ClIMATE CHANGE 679, 683 (2011).

98. FIRST 2011 DOE REPORT, supra note 10, at 17 (noting that Howarth's study's conclusion is "not widely accepted").

99. See, e.g, Jacoby, O'Sullivan \& Paltsev, supra note 34, at 44 n.2 (criticizing Howarth for "questionable interpretation of methane leakage data" and for assuming "inappropriate substitution of gas for coal generation"); Francis O'Sullivan \& Sergey Paltsev, Shale Gas Production: Potential Versus Actual Greenhouse Gas Emissions, 7 ENVTL. RES. LETTERS 6 (2012), available at http://m.iopscience.iop.org/1748-9326/7/4/044030/pdf/1748-9326_7_4_044030 .pdf (rebutting the Howarth study and arguing that methane emissions from fractured natural gas wells are comparable to methane emissions from conventional gas drilling); see also MARY LASHLEY BARCELLA ET AL., IHS CAMBRIDGE ENERGY RESEARCH ASSOCS., MismEASURING METHANE: EsTIMATING GREENHOUSE GAS EMISSIONS FROM UPSTREAM NATURAL GAS DEVELOPMENT, PRIVATE REPORT 9 (2011) ("IHS data ... was misused and severely distorted in the Howarth paper. The analysis included wells that were not in the 
and a number of methodological and empirical questions need to be resolved.

For example, when we analyze whether natural gas or coal contributes more to greenhouse gas emissions and climate change on a life-cycle basis, time horizon is an important issue. Methane traps more heat than carbon dioxide, but only as long as it remains in the atmosphere-for only twenty years, compared with 100 years for carbon dioxide. ${ }^{100}$ As a result, estimates of methane's impact over a twenty year time horizon are greater than over a 100 year time horizon, but the latter is probably a better measure of long-run effects on climate. ${ }^{101}$

Another key question in this life-cycle comparison is the rate of methane leakage from natural gas production. Estimates range from a low of $1 \%$ to a high of $5 \%$ or even $8 \% .{ }^{102}$ In an April 2013 study, the Environmental Protection Agency (EPA) offered a reassuring assessment, concluding that methane emissions declined by $8.2 \%$ between 1990 and $2011 .^{103}$

flowback phase at all; double-counted a particularly prolific well; and in the single case of a well tested during the flowback process, assumed that methane was emitted when in fact it was captured for sale, as clearly stated in the IHS report."); id. ("The Howarth paper states that methane emissions from unconventional gas wells average nearly 2 percent of the ultimate recovery of natural gas over the lifetime of the well ... . By contrast, the authors estimate that flowback methane emissions from a conventional gas well average only 0.01 percent of ultimate recovery.").

100. Global Warming FAQ, UNION OF CONCERNED SCIENTISTS, http://www .ucsusa.org/global_warming/science_and_impacts/science/global-warming-faq .html (last visited Oct. 17, 2013).

101. James Bradbury et al., Clearing the Air: Reducing Upstream Greenhouse Gas Emissions from U.S. Natural Gas Systems, 14-15 (World Resources Institute, Working Paper Apr. 2013), available at http://pdf.wri.org/clearing the_air_full.pdf; David B. Spence, Responsible Shale Gas Production: Moral Outrage vs. Cool Analysis, 24 FoRDHAM ENVTL. L. REV. (forthcoming 2013), available at $\mathrm{http}: / / \mathrm{ssrn} . c o m / a b s t r a c t=2228398$. See generally Michael A. Levi, Comment on "Hydrocarbon Emissions Characterization in the Colorado Front Range: A Pilot Study" by Gabrielle Pétron et al., 117 J. GEOPHYSICAL RES. D21203 (2012) (measuing methane emissions from natural gas).

102. Ramon A. Alvarez et al., Greater Focus Needed on Methane Leakage from Natural Gas Infrastructure, 109 PROC. NAT'L ACAD. SCI. 6435, 6437 (2012) (concluding that the cumulative leakage rate from natural-gas production is $3.2 \%$ ); Michael Levi, Climate Consequences of Natural Gas as a Bridge Fuel, 118 ClimatiC CHANGE 609, 620 (2013) ("Most recent publications have indicated that leakage in the United States is likely to be 1-2\%, and have all but rejected the possibility of leakage on the order of 5 percent. . .."); Jeff Tollefson, Methane Leaks Erode Green Credentials of Natural Gas, 493 NATURE 12, 12 (2013) (reporting on preliminary data from joint study by National Oceanic and Atmospheric Administration and the University of Colorado indicating leakage rate may be as high as $9 \%$ ).

103. EPA, supra note 96 , at ES-12 
Although this period coincides with a dramatic increase in natural gas production, methane emissions from natural gas production are down even more-by $10.2 \%{ }^{104}$ This progress is "due largely to a decrease in emissions from transmission and storage," EPA concluded, "due to increased voluntary reductions and a decrease in distribution emissions due to a decrease in cast iron and unprotected steel pipelines." ${ }^{105}$ Likewise, the subset of methane leaks attributed to field production (as opposed to pipelines) is down even more sharply-by $12 \%{ }^{106}$ This decline has not been linear: EPA reports that methane field production emissions actually increased by $43 \%$ from 1990 through 2006, and then declined by 38\% from 2006 through 2011, even though this later period is when the shale gas boom took off. ${ }^{107}$ Compared with the assessment it issued in 2012, EPA's 2013 assessment is significantly more favorable: it reduced its estimate (a) of total methane emissions in 2010 by $11 \%$ and (b) of methane emissions from natural gas systems in 2010 by $33 \%{ }^{109}$ According to EPA's 2013 report, U.S. natural gas production emits only slightly more methane into the atmosphere than livestock (i.e., from "enteric fermentation" or belches). ${ }^{110}$ Like-

104. Id. at ES-13 (reporting decline of $16.5 \mathrm{Tg} \mathrm{C} 02 \mathrm{Eq}$. ).

105. Id.

106. Id.

107. Id.

108. Compare EPA, INVENTORY OF U.S. GREENHOUSE GAS EMISSIONS AND SINKS: 1990-2010, at ES-5 (2013), available at http://www.epa.gov/ climatechange/Downloads/ghgemissions/US-GHG-Inventory-2012-ES.pdf (reporting 666.5 teragrams carbon dioxide equivalent for 2010 in their 2012 report), with EPA, INVENTORY OF U.S. GREENHOUSE GAS EMISSIONS AND SINKS: 1990-2011, at ES-6 (2013), available at http://www.epa.gov/climatechange/ Downloads/ghgemissions/US-GHG-Inventory-2013-Main-Text.pdf (reporting 592.7 teragrams carbon dioxide equivalent for 2010 in their 2013 report). The change from 666.5 to 592.7 is an $11 \%$ decline.

109. Compare EPA, INVENTORY OF U.S. GREENHOUSE GAS EMISSIONS AND SINKS: 1990-2010, at ES-5 (2013), available at http://www.epa.gov/ climatechange/Downloads/ghgemissions/US-GHG-Inventory-2012-ES.pdf (reporting 215.4 teragrams carbon dioxide equivalent for natural gas systems in 2010 in their 2012 report), with EPA, INVENTORY OF U.S. GREENHOUSE GAS EMISSIONS AND SINKS: 1990-2011, at ES-6 (2013), available at http://www .epa.gov/climatechange/Downloads/ghgemissions/US-GHG-Inventory-2013 -Main-Text.pdf (reporting 143.6 teragrams carbon dioxide equivalent for natural gas systems in 2010 in their 2013 report). The change from 215.4 to 143.6 is a $33 \%$ decline.

110. EPA, INVENTORY OF U.S. GREENHOUSE GAS EMISSIONS AND SINKS: 1990-2011, at ES-12-ES-13 (2013), available at http://www.epa.gov/ climatechange/Downloads/ghgemissions/US-GHG-Inventory-2013-Main

-Text.pdf; EPA Methane Report Further Divides Fracking Camps, WALL ST. J., Apr. 28, 2013, http://online.wsj.com/article/APe433c8a9448749f38fc513232d72 
wise, a September 2013 study organized by the Environmental Defense Fund also finds relatively little methane leakage during the natural gas extraction process, based on measurements from 190 onshore production sites; the measurements are in line with EPA's most recent estimates, although the distribution is somewhat different (with lower emissions from well completion and higher emissions from pneumatic controllers and equipment leaks). ${ }^{111}$ Further research will hopefully yield a more definitive assessment over time.

What is clear, though, is that as long as methane leakage can be contained at the low end of this range, switching from coal to natural gas is beneficial from a climate perspective. ${ }^{112}$ Fortunately, there are cost effective measures to contain methane leaks and energy companies have an economic incentive to adopt them, so they can sell the methane that otherwise would escape. ${ }^{113}$ They also have safety reasons to minimize methane leaks, since methane is highly flammable and inhaling it can cause dizziness, headaches, and other symptoms. ${ }^{114}$ In addition, EPA's recently promulgated regulations on fugitive emissions reinforce this incentive, requiring energy companies to capture or burn methane released during drilling (so-called

d1e2.html (reporting 145 million metric tons annually from natural gas production versus 137 million from livestock).

111. David T. Allen et al., Measurements of Methane Emissions at Natural Gas Production Sites in the United States, PROC. NAT. ACAD. SCIENCE 1 (2013).

112. See Alvarez et al., supra note 102, at 6435; Andrew Burnham et al., Life-Cycle Greenhouse Gas Emissions of Shale Gas, Natural Gas, Coal, and Petroleum, 46 ENVTL. SCI. \& TECH. 619, 624 (2011) (concluding that, on a lifecycle basis, electricity generated from coal produces $41 \%$ more greenhouse gas emissions than electricity from conventional natural gas, while electricity from shale gas produces $6 \%$ less greenhouse gas emissions than electricity from conventional gas); Timothy J. Skone, Life Cycle Greenhouse Gas Analysis of Natural Gas Extraction \& Delivery in the United States, U.S. DEP'T OF ENERGY 34 (last visited Sept. 26, 2013), http://www.netl.doe.gov/energy-analyses/pubs/ NG_LC_GHG_PRES_12MAY11.pdf (illustrating the Department of Energy's analysis concluding that power generation from natural gas produces $54 \%$ less greenhouse gas than from coal on a life-cycle basis with a 100 year time horizon); Paulina Jaramillo et al.Comparative Life-Cycle Air Emissions of Coal, Domestic Natural Gas, LNG, and SNG for Electricity Generation, 41 ENVTL. SCI. \& TECH. 6290, 6293 (2007) (concluding that life-cycle carbon dioxide emissions from electricity generated with domestically produced natural gas is $50 \%$ less than electricity generated from coal, though the difference is narrower for liquefied and synthetic natural gas).

113. 2011 MIT STUDY, supra note 4, at 133 (noting both "environmental and business reasons" to capture emissions from methane leaks).

114. BARCELLA ET AL., supra note 99, at 1-2 (noting incentive of energy companies to minimize methane emissions for health and safety reasons). 
"green capture" and "flaring") and mandating various other control technologies. ${ }^{115}$

\section{FAMILIAR RISKS THAT ARE NOT UNIQUE TO FRACTURING}

Balanced against the benefits of fracturing are a number of potential risks. In our view, the most important of these-and, indeed, the one that is unique to fracturing - is the risk of contaminating groundwater. We describe this risk in Part IV and consider how to address it in Parts V, VI, and VII.

But before we turn to water contamination, Part III reviews five other environmental risks: the economic competition that shale gas and oil pose to renewable energy; air pollution; congestion and pressure on local communities; water usage; and induced tremors and earthquakes. A unifying theme among these risks is that they are not unique to fracturing. Almost all arise, for instance, when oil and natural gas wells are drilled conventionally (i.e., without fracturing and horizontal drilling). ${ }^{116}$ Some of these risks also arise in coal mining, manufacturing, and even in opening new sports arenas and shopping malls. Because these risks are familiar in other contexts, most are already governed by existing regulatory regimes. While fracturing might justify an increase in the scale or intensity of these regulations, in most cases it is unlikely to require new fracturing-specific regimes for these risks.

\section{A. ECONOMIC COMPETITION FOR SOLAR, WIND, AND OTHER RENEWABLES}

By increasing the supply of natural gas and oil, and thus holding down their prices, fracturing diminishes price-based incentives to conserve energy. Does it also impede the development of renewable energy, such as solar, wind and geothermal?

Arguably, the answer is "no." To the extent government initiatives guarantee a percentage of the energy market to renewable energy, shale gas does not undercut the incentive to use renewables because it is not a renewable fuel. ${ }^{117}$ Aside from

115. New Source Performance Standards and National Emission Standards for Hazardous Air Pollutants Reviews, 77 Fed. Reg. 49,490 (Aug. 16, 2012) (to be codified at 40 C.F.R. pt. 63).

116. Christopher L. Weber \& Christopher Clavin, Life Cycle Carbon Footprint of Shale Gas: Review of Evidence and Implications, 46 ENVTL. SCI. \& TECH. 5688 (2012).

117. JANSEN \& LEVINE, supra note 39 , at 40 (noting that utilities invest in 
the protection afforded by such mandates, shale gas is often viewed as a bridge fuel, which will help satisfy the nation's energy needs until renewables are more competitive. ${ }^{118}$ In addition, since wind and solar are intermittent sources of energy, they need another source to fill in when they are unavailable, which usually is natural gas. ${ }^{119}$

Nevertheless, there is a risk that cheap natural gas will undercut the political support for renewable fuel mandates and, more generally, will outcompete renewables so that they never become economically viable. ${ }^{120}$ Although opponents of fracturing do not usually say so explicitly, one reason some may favor a moratorium or costly new regulations for fracturing is to shore up the competitive position of renewables.

While we agree with the goal of using taxes and other policy instruments to ensure that carbon fuel prices reflect their true social cost, including externalities-and have made a proposal in this spirit elsewhere ${ }^{121}$ - this strategy does not make sense if applied only to shale gas and oil, but not to other carbon fuels. If fracturing is banned or becomes significantly more expensive, while coal remains cheap, the result will not be more solar and wind energy, but more coal. ${ }^{122}$ This is not an outcome

renewables in part because of state-based renewable portfolio standards).

118. 2011 MIT STUDY, supra note 4 , at 70 ("Gas can be an effective bridge to a lower $\mathrm{CO}_{2}$ emissions [in the] future ....").

119. IHS, NATIONAL ECONOMIC CONTRIBUTIONS, supra note 3, at 16; 2011 MIT STUDY, supra note 4, at 73 (claiming natural gas provides baseload power and system flexibility for intermittent sources).

120. Ryan Tracy, States Cooling to Renewable Energy, WaLl ST. J., Mar. 28,2013 , at $\mathrm{A} 3$ ("Legislatures in half the states that require electric utilities to buy renewable energy are considering proposals to roll back those mandates."); 2011 MIT STUDY, supra note 4, at 2 ("[N]atural gas sets the cost benchmark against which other clean power sources must compete to remove the marginal ton of $\mathrm{CO}_{2}$."); id. at 10 (noting that in some short- and long-term scenarios, renewables and gas substitute for each other on a nearly one-for-one basis); $i d$. at 54 (estimating cost per kilowatt hour of electricity is 5.4 cents for coal, 5.6 cents for gas, 6.0 cents for wind, 8.5 cents for biomass, and 19.3 cents for solar, without including cost of backup and storage for renewables, which would lead to a higher estimate); Jacoby et al., supra note 34, at 49 (modeling the effect of cheap shale gas on economic viability of renewables through 2050 and finding that "cheaper gas serves to reduce the rate of market penetration of renewable generation").

121. Thomas Merrill \& David M. Schizer, Energy Policy for an Economic Downturn: A Proposed Petroleum Fuel Price Stabilization Plan, 27 YALE J. ON REG. 1 (2010).

122. Susan L. Brantley \& Anna Meyendorff, Op-Ed., The Facts on Fracking, N.Y. TIMES, Mar. 14, 2013, http://www.nytimes.com/2013/03/14/ opinion/global/the-facts-on-fracking.html?pagewanted=all\&_r=0. 
that environmentalists should favor, since gas burns more cleanly than coal. Any such effort to reduce consumption of carbon fuels should apply in an even-handed manner to all carbon fuels.

The global nature of climate change and energy production reinforces this point. Even if the U.S. bans fracturing, other countries will use it. ${ }^{123}$ For example, there are large shale oil and gas reserves in China, Argentina, Ukraine, Poland, Libya, Algeria, and in other nations as well; although it may take some time for these nations to develop their capacity for shale drilling, they presumably will do so eventually. ${ }^{124}$ If these resources undercut the development of renewables, there is little the United States (alone) can do to stop them. An effort to stop fracturing in the U.S. could therefore deprive the U.S. of the benefits of fracturing without doing much to hasten the development of renewables on a global basis.

\section{B. Air POLLUTION}

Another environmental risk from drilling in shale beds is air pollution, which can arise in four ways. First, methane can be released from a well or a leak in a pipeline, as discussed above, contributing to greenhouse gas emissions, ${ }^{125}$ and in rare cases can even cause explosions. Of course, methane emissions arise not just from fractured wells, but also from conventional wells, ${ }^{126}$ pipelines, and, for that matter, from landfills and cattle

123. MEDLOCK ET AL., supra note 36, at 11 (noting that shale gas production is being discussed in Europe, China, India, and Australia); 2011 MIT STUDY, supra note 4, at 154 (noting that China has 1.2 trillion cubic feet of natural gas reserves).

124. Russell Gold \& Marynia Kruk, Global Gas Push Stalls, WaLl ST. J., Dec. 3, 2012, at A1 (noting that other nations lag behind the U.S. in technical capacity as well as in knowledge of geological conditions, and also that the U.S. property rights system, which vests landowners as opposed to the state with mineral rights, creates added incentive to drill); id. at A6 (noting also that other countries are likely to catch up to the U.S. eventually, though it may take time). France, on the other hand, has indicated that it will not permit fracturing. See Op-Ed., No Fracking, We're French, WALL ST. J., Sept. 20, 2012, at A16.

125. See generally Robert W. Howarth et al., Methane and the GreenhouseGas Footprint of Natural Gas from Shale Formations, 106 CLIMATIC CHANGE 679 (2011).

126. Indeed, a number of studies have compared air pollution and emissions from conventional and shale gas. See Weber \& Clavin, supra note 116, at 5688. Although there is some uncertainty on the question, the evidence so far suggests that life-cycle emissions from conventional and shale gas are comparable. See, e.g., Christopher L. Weber \& Christopher Clavin, Life Cycle Carbon 
ranches. ${ }^{127}$ Over time, we will have better information about the life-cycle emissions of shale and other sources of energy, so that more definitive judgments can be made and additional regulatory steps can be considered as needed. In any event, we do not offer a comprehensive analysis of this issue, since this Article focuses on water contamination.

Second, fracturing fluid can contain volatile organic compounds (VOCs), such as benzene, which can be released into the atmosphere when the fluid evaporates. ${ }^{128}$ VOCs can increase the risk of cancer, as well as asthma, nausea, and other symptoms. ${ }^{129}$ As a result, some states monitor VOC emissions near drilling sites (e.g., Texas), ${ }^{130}$ while others require energy companies to use "vapor recovery systems" or holding tanks to minimize VOC emissions (e.g., Colorado) ${ }^{131}$ In addition, EPA's new regulations are expected to reduce VOC emissions from the oil

Footprint of Shale Gas: Review of Evidence and Implications, 46 ENVTL. SCI. \& TECH. 5688, 5693 (2012) ("Our review of several studies published since Howarth's initial shale gas carbon footprint study shows that although the carbon footprint of shale gas is highly uncertain, it is also difficult to distinguish from conventional onshore gas production.") (footnote omitted).

127. Overview of Greenhouse Gases, EPA, http://www.epa.gov/ climatechange/ghgemissions/gases/ch4.html (last visited Oct. 17, 2013) (cataloging various sources of methane emissions, including landfills, animal husbandry, natural gas production, coal mining, and wastewater treatment). According to EPA, animal husbandry produced nearly as much methane emissions as natural gas systems in 2009 . Id. (189 $\mathrm{TgCO} 2$ compared to 221 $\mathrm{TgCO} 2$ ).

128. Theo Colborn et al., Natural Gas Operations From a Public Health Perspective, 17 HUM. \& ECOLOGICAL RISK ASSESSMENT: INT'L J. 1039, 1040-42 (2011).

129. Id. at 1045-46; see also The Potential Health Impacts of Hydraulic Fracking Wastewater and Drill Cuttings: Hearing before the N.Y. State Assemb. Standing Comms. on Envtl. Conservation \& Health (May 26, 2011) (statement of Sandra Steingraber, Distinguished Scholar in Residence, Ithaca College), available at http://fingerlakescleanwaters.org/?page_id=94 (describing possible health effects from air polluted with benzene and other toxic chemicals).

130. See A Commitment to Air Quality in the Barnett Shale, 'TEX. COMM'N ON ENVTL. QUALITY, http://www.tceq.texas.gov/publications/pd/020/10-04/a -commitment-to-air-quality-in-the-barnett-shale (last visited Oct. 17, 2013) (noting that "the "TCEQ has committed a tremendous amount of time and resources to the issue of Barnett Shale air quality, and we will continue to do so," and that twenty-four hour air quality monitors have been operating for several months) (quoting Chairman Bryan Shaw).

131. Rule 805 Air Quality \& Odor, COLORADO OIL \& GAS CONSERVATION COMMISSION, http://cogcc.state.co.us/RR_Training/presentations/805_ AirQuality.pdf (slide presentation describing new Rule 805.b(2) requiring control devices in condensate tanks). 
and gas industry by $25 \%{ }^{132}$ This would be useful, since EPA estimates that the oil and gas industry is the largest industrial source of VOC emissions. ${ }^{13}$ Still, other activities, such as car emissions and smoking, are equally significant. ${ }^{134}$ Indeed, after a high profile charge that elevated VOC levels near drilling sites causing health effects in Dish, Texas, ${ }^{135}$ studies by Texas authorities found that VOC levels in the air generally were not elevated. ${ }^{136}$ They also found that biological tests of Dish resi-

132. Proposed Amendments to Air Regulations for the Oil and Natural Gas Industry Fact Sheet, EPA, http:/www.epa.gov/airquality/oilandgas/pdfs/ 20110728factsheet.pdf (last visited Oct. 17, 2013) ("The proposal would cut smog-forming volatile organic compound (VOC) emissions by nearly one-fourth across the oil and gas industry, including a nearly 95 percent reduction in VOCs emitted from new and modified hydraulically fractured gas wells."); see also New Source Performance Standards and National Emission Standards for Hazardous Air Pollutants Reviews, 77 Fed. Reg. 49,490 (Aug. 16, 2012) (to be codified at 40 C.F.R. pt. 63), available at http://epa.gov/airquality/ oilandgas/pdfs/20120417finalrule.pdf (final rule requiring VOC containment vessels to reduce VOC emissions by $95 \%$ ).

133. Oil and Natural Gas Air Pollution Standards, Basic Information, EPA, http://www.epa.gov/airquality/oilandgas/basic.html (last visited Sept. 10, 2013). The precise contribution of the oil and gas industry is contested.

134. See, e.g., BARBARA ZIELINSKa ET AL., DESERT RES. INST., MONITORING of EMISSIONS FROM BARNETT SHale NATURAL GaS PRODUCTION FACILITIES FOR POPULATION EXPOSURE ASSESSMENT (2010), available at https://sph.uth .edu/mleland/attachments/Barnett\%20Shale\%20Study\%20Final\%20Report.pdf (study of VOC emissions in Texas finding that "the dominant source category was motor vehicle emissions to which $46 \pm 14 \%$ was attributed," while "[c]ombined natural gas and condensate tank emissions were estimated to contribute about the same amount; $43 \pm 5 \%$," and "[s]mall gasoline engines (e.g. lawnmowers) accounted for about $17 \pm 7 \%$ of the total").

135. Wolf Eagle Environmental did a study showing elevated benzene levels in Dish, Texas, near Fort Worth, and the Earthworks Accountability project conducted a survey of health effects. See WOLF EAGLE ENVTL., TOWN OF DISH TEXAS AMBIENT AIR MONITORING ANALYSIS FINAL REPORT (2009), available at http://townofdish.com/objects/DISH__final_report_revised.pdf ("Laboratory results confirmed the presence of multiple Recognized and Suspected Human Carcinogens . . . ."); WILMA SUBRA, EARTHWORKS OIL AND GAS ACCOUNTABILITY PROJECT RESUlTS OF HEALTH SURVEY OF CURRENT AND FORMER DISH/CLARK, TEXAS RESIDENTS (2009), available at http://www .earthworksaction.org/files/publications/DishTXHealthSurvey_FINAL_hi.pdf (noting that $19 \%$ of survey participants described themselves as either sick, or "both healthy and sick," and that " $61 \%$ of the health impacts reported by participants are known health effects of chemicals detected in the air").

136. See Press Release, R.R. Comm'n of Tex., Chairman Carrillo Issues Statement on Barnett Shale Emissions Issues (Jan. 13, 2010), available at http://www.rrc.state.tx.us/pressreleases/2010/011310.php (statement by the Chair of the Texas Commission on Environmental Quality reporting results of air quality study that found "no cause for concern"). According to John Sadlier, Deputy Director of the Office of Compliance and Enforcement, "the majority of the testing during that trip found no detection of volatile organic compounds 
dents revealed elevated VOC's only among smokers. ${ }^{137}$ Hopefully, further research will provide greater certainty on these issues.

Third, fracturing involves drilling deep under the earth, where there are so-called "naturally occurring radioactive materials" or "NORMs," and the drilling process can bring these to the surface. ${ }^{138}$ There is a debate about whether this material poses health risks to drillingworkers and others. ${ }^{139}$ In any event, the same issue can arise with conventional drilling, ${ }^{140}$ and states and the federal government have various regulations in place addressing this risk. ${ }^{14}$

Finally, drilling equipment and trucks produce emissions. ${ }^{142}$ Conventional wells pose the same issue, as do factories and shopping malls. Substituting equipment and trucks powered by natural gas instead of diesel will help mitigate this problem, and low natural gas prices offer an added incentive to do so. ${ }^{143}$

at all ...." Id.

137. Press Release, Tex. Dep't of State Health Servs., Tests Indicate Exposures in Dish Similar to U.S. Population (May 12, 2010), available at http:// www.dshs.state.tx.us/news/releases/20100512.shtm ("Biological test results from a Texas Department of State Health Services investigation in Dish, Texas, indicate that residents' exposure to certain contaminants was not greater than that of the general U.S. population .... The only residents who had higher levels of benzene in their blood were smokers. Because cigarette smoke contains benzene, finding it in smokers' blood is not unusual.").

138. Craig Slatin \& Charles Levenstein, An Energy Policy that Provides Clean and Green Policy, 23 NEW SoluTIONS 1, 16 (2013).

139. For example, a study by Radioactive Waste Management Associates concluded that there were risks to workers and possibly also to farmers. MARVIN RESNIKOFF ET AL., RADIOACTIVE WASTE MANAGEMENT ASSOCIATES, RADIOACTIVITY IN MARCELLUS SHALE (2010), available at http://energy.wilkes .edu/PDFFiles/Library/Marcellus\%20Shale\%20Radioactivity\%20Report\%205

-18-2010.pdf. In response, another study questioned their assumptions and concluded that the risks are minimal. See Lynn Kerr McKay et al., Science and the Reasonable Development of Marcellus Shale Natural Gas Resources in Pennsylvania and New York, 32 ENERGY L.J. 125, 129-30 (2011) (arguing that radioactivity risk is minimal).

140. For example, EPA's discussion of the issue on the webpage indicates that one potential source of exposure is from wells drilled before the 1970 s when the regulations went into effect. This obviously was long before fracturing in shale beds began. Radioactive Wastes from Oil and Gas Drilling, EPA, http://www.epa.gov/radtown/drilling-waste.html (last updated Aug. 14, 2012).

141. Id. ("Most states and federal land management agencies currently have regulations which control the handling and disposal of radionuclides which may be present in production sites.").

142. FIRST 2011 DOE REPORT, supra note 10, at 15.

143. Id. at 24 . 


\section{Congestion and Pressure on Local Communities}

Environmental pressure of a different kind arises from the influx of workers when oil or natural gas is discovered in a shale bed. A population surge can put pressure on the local housing stock, schools, and other services. Drilling can be noisy. ${ }^{144}$ There is more traffic and, thus, additional wear and tear on roads. ${ }^{145}$ Pipelines may be needed to bring in fracturing fluid or to transport oil and gas. ${ }^{146}$ All this activity can disrupt local habitats. ${ }^{147}$

These challenges often arise with new economic activity that brings jobs and purchasing power to rural areas, including new conventional gas' wells, coal mines, factories, and shopping malls. In managing these costs, municipalities already have a host of policy instruments, from land use regulation, to conditioning drilling permits, to taxes and fines. ${ }^{148}$ For example, municipalities can require energy company trucks to follow designated routes or firms to post a bond and pay for the creation or maintenance of roads. ${ }^{149} \mathrm{Or}$, as Pennsylvania has done, the state can impose "impact fees" on energy companies, a portion of which are dedicated to repairing local roads and bridges. ${ }^{150}$

144. SEC'Y OF ENERGY AdVISORY Bd., SHALE GaS PRODUCTION SUBCOMMITTEE SECOND 90-DAY REPORT 8 (2011), available at http://www.shalegas .energy.gov/resources/111811_final_report.pdf thereinafter SECOND 2011 DOE REPORT] (noting potential impact on traffic, noise, land use, wildlife, and habitats).

145. Nat'l PaRK Serv., U.S. DeP'T of the INTERIor, Potentlal DeVelOPMENT OF THE NATURAL GAS RESOURCES IN THE MARCELLUS SHALE 8 (Dec. 2008), available at http://www.eesi.psu.edu/seminars-conferences/earthtalks -spring2009-marcellus-supplements/NatParkService-GRD-M-Shale_12-11 -2008_view.pdf (a single well can require between 320 and 1365 truckloads of equipment).

146. 2011 MIT STUDY, supra note 4, at 4.

147. SECOND 2011 DOE REPORT, supra note 144, at 8.

148. See 2011 MIT STUDY, supra note 4, at 38 (noting that energy companies must obtain a permit before drilling a well).

149. See N.Y. State DeP'T of EnvTl. Conservation, Revised Draft SUPPLEMENTAL GENERIC ENVIRONMENTAL IMPACT STATEMENT ON THE OIL, GaS AND SOlUtion MINING REGULATORY PROGRAM 7-143 (2011), available at $\mathrm{http} / / /$ www.dec.ny.gov/data/dmn/rdsgeisfull0911.pdf ("Municipalities may require trucks transporting hazardous materials to travel on designated routes, in accordance with a road use agreement ...."); Ryan Delaney, Fracking Will Bring Heavy Truck Traffic, But Towns Are Ready, InNOVATION TraIl (Sept. 4, 2012, 3:40 PM), http://innovationtrail.org/post/fracking-will-bring-heavy-truck -traffic-towns-are-ready (explaining Steuben County requires energy companies to post a $\$ 250,000$ bond or to pay to upgrade the road and post a $\$ 15,000$ bond).

150. See 58 P.A. Cons. STAT. $\$ 2302$ (2012). 
It is worth emphasizing, moreover, that drilling in shale has an important advantage over conventional drilling in this regard. When horizontal drilling is used, fewer drill pads are needed on the surface, since a single pad can be used for multiple wells. ${ }^{151}$ There is also more flexibility about where the drill pad is located. If a deposit is found near a school, for instance, the well does not have to be right next to the school, as with conventional drilling; instead, it can be some distance away, using horizontal drilling below the surface to access the deposit. ${ }^{152}$

\section{WATER USAGE}

Fracturing also requires a significant amount of water. A single well uses 2 to 4 million gallons. ${ }^{153}$ EPA estimates that fracturing will consume as much water as 5 million people if 35,000 wells are fractured each year. ${ }^{154}$

Whether this demand is easy or hard to satisfy depends on the local water supply where the wells are drilled. For instance, according to a recent study of water resources, "the area overlying the Marcellus Shale [in Pennsylvania and New York] has abundant precipitation, making water readily available." More generally, "[w]hile water availability varies across the country," a 2011 Department of Energy Report observes, "in most regions water used in hydraulic fracturing represents a small fraction of total water consumption." where shale gas drilling takes place, it uses less than $1 \%$ of the state's water (e.g., less than $.1 \%$ in Pennsylvania). ${ }^{157}$ Even so,

151. See FIRST 2011 DOE REPORT, supra note 10, at 26 (noting that multiwell drill pads minimize traffic).

152. NAT"L PARK SERV., supra note 145, at 4 ("While the horizontal drilling and hydraulic fracturing practices expected to be used in developing the Marcellus Shale may have negative environmental effects on the surrounding area, when compared to development of conventional oil and gas resources this development method could result in fewer impacts than conventional vertical wells due to greater flexibility in well location.").

153. EPA 2012 PROGRESS REPORT, supra note 4, at 80.

154. EPA, Plan to Study the Potential ImPaCts of Hydraulic Frac. TURING ON DRINKING WATER RESOURCES 22 (2011), available at http://water .epa.gov/type/groundwater/uic/class2/hydraulicfracturing/upload/hf_study_ plan_110211_final_508.pdf [hereinafter EPA 2011 PLAN].

155. J. DANIEL ARTHUR ET AL., WATER RESOURCES AND USE FOR HYDRAULIC FRACTURING IN THE MARCELLUS SHALE REGION 2, available at http://www .netl.doe.gov/technologies/oil-gas/publications/ENVreports/FE0000797_

WaterResourceIssues.pdf.

156. FIRST 2011 DOE REPORT, supra note 10, at 19.

157. 2011 MIT STUDY, supra note 4 , at $43-44$. 
water supplies are constrained in Colorado, as well as in some counties in Texas where fracturing takes place. ${ }^{158}$

In using water, shale gas drilling is no different from many other economic activities. In Texas, for example, $56 \%$ of the state's annual water consumption is for irrigation, $26 \%$ is for municipal use, and less than $1 \%$ is for shale gas. ${ }^{159}$ Likewise, livestock uses significantly more water in all states where shale gas drilling takes place. ${ }^{160}$ Shale gas also uses less water per unit of energy than many forms of energy, and is comparable to coal. ${ }^{161}$

Of course, it is more economical to use water that is extremely close to drilling sites, and in some locations water is scarce in the immediate vicinity. ${ }^{162}$ Localities already have systems in place to allocate water rights and regulate water usage. ${ }^{163}$ Some require permitting or water usage plans. ${ }^{164}$ The

158. MONIKA Freyman \& RYAN SALmon, CEREs, Hydraulic Fracturing \& WATER STRESS: GROWING COMPETITIVE PRESSURES FOR WATER 3 (2013), available at https://www.ceres.org/resources/reports/hydraulic-fracturing -water-stress-growing-competitive-pressures-for-water (analyzing stresses that fracturing imposes on water supply).

159. Jean-Philippe Nicot \& Bridget R. Scanlon, Water Use for Shale-Gas Production in Texas, U.S., 46 ENVTL. SCI. \& TECH. 3580, 3584 (2012).

160. 2011 MIT STUDY, supra note 4, at 44. In the Barnett Shale in Texas, for example, .4\% of local water is used for shale gas drilling, compared with $2.3 \%$ for livestock. $I d$.

161. Id. (noting that shale gas's water needs are "low compared to many other energy sources" and comparing shale gas, which uses 1 gallon of water per Million British thermal units (MMBtu) of energy, with ethanol, which uses several thousand gallons of water per MMBtu); Nicot \& Scanlon, supra note 159 , at 3585 ("Texas shale gas has a cumulative water use efficiency of 8.3$10.4 \mathrm{~L}$ per gigajoule (L/GJ) . . . [D] ata collected in this study (including 8.3-16.6 L/GJ for coal and 6.1 L/GJ for uranium) show that net water use for shale gas is within the same general range as that for other energy sources."). Shale gas uses water at the beginning of production, while coal uses it throughout the mining process. Nicot \& Scanlon, supra note 159, at 3585.

162. See ARTHUR ET AL., supra note 155 , at 2 (" $[G]$ round and surface water sources most proximal to the well sites are most desirable."). See also Nicot \& Scanlon, supra note 159 , at 3583 tbl. 2, for a county-by-county analysis in Texas.

163. Hannah J. Wiseman, Risk and Response in Fracturing Policy, 84 U. COLO. L. REV. 101, 147-48 (2013).

164. See ARTHUR, URETSKY \& WILSON, supra note 155 , at 2 (" $[\mathrm{A}]$ primary issue for water withdrawal will be the regulations governing permitting procedures . . . from the water bodies nearest the wells. In New York, Pennsylvania and West Virginia, withdrawal permitting is regulated by a matrix of state and interstate regulatory agencies, whose regulations reflect the needs of individual states or watersheds."). 
bottom line is that, if energy companies cannot buy water locally, they have to pipe or truck it in.

Fortunately, the issue has become less important since energy companies began reusing (or "recycling") fracturing fluid; in some areas, they reuse $80 \%$ of it. ${ }^{165}$ Not only does recycling reduce the amount of water needed for fracturing, but it also diminishes the volume of fracturing waste, easing the challenge of disposing of it. ${ }^{166}$

\section{E. INDUCED TREMORS AND EARTHQUAKES}

Finally, there have been reports that fracturing can cause tremors and minor earthquakes. There is one confirmed case of seismic activity induced by fracturing in Blackpool, England, and another possible case in Oklahoma. ${ }^{167}$ In each instance, the seismic disturbance was small and caused no surface damage. ${ }^{168} \mathrm{~A}$ thorough study of the issue by the National Research Council concludes that seismic events from fracturing will be "small and rare," most likely "due to the short duration of injection of fluids and the limited fluid volumes used in a small spatial area."

There is greater potential for earthquakes from disposal of spent fracturing fluid in injection wells. Seismic activity related to disposal of fracturing waste in injection wells has led to regulatory responses in Ohio and Arkansas. ${ }^{170}$ But the risk here is

165. Jeff Bell, Fracking Injection Wells Booming but Need May Lessen with Time, BUSINESS FIRST (Nov. 23, 2012), http://www.bizjournals.com/columbus/ print-edition/2012/11/23/fracking-injection-wells-booming-but.html?page=all (stating $80 \%$ of fracturing fluid in Pennsylvania is recycled).

166. EPA 2012 PROGRESS REPORT, supra note 4, at 104.

167. NAT'L RESEARCH COUNCIL, THE NAT'L ACADS., INDUCED SEISMICITY Potential IN ENERgy TECHNOLOGIES 156 (2012); Katie M. Keranen et al., Potentially Induced Earthquakes in Oklahoma, USA: Links Between Wastewater Injection and the $2011 M_{w} 5.7$ Earthquake Sequence, 41 GEOLOGY 699,702 (2013) (concluding that an Oklahoma earthquake was caused by wastewater injection well); see also John Tagliabue, Parts of Low Country Are Now Quake Country, N.Y. TrMES, Mar. 26, 2013, http://www.nytimes.com/ 2013/03/27/world/europe/more-earthquakes-in-loppersum-the-netherlands .html?pagewanted=all\&_r $r=1 \&$ (describing minor earthquakes in the Netherlands that may be related to natural gas drilling, although the drilling is in porous rock and does not involve fracturing).

168. NAT'L RESEARCH COUNCIL, supra note 167 , at 3 .

169. Id. at 8,93 .

170. Ohio has amended its injection well regulations to require investigation of geological fault lines and monitoring for seismic activity. OHIO ADMIN. CODE 1501:9-3-06(C)(2)-(3) (2012). Arkansas has proposed a moratorium on injection wells in an area where seismic activity was detected. Request for an 
no different from disposal of waste water from conventional oil and gas production or waste from other industrial operations. ${ }^{171}$ Indeed, the greatest risk of seismic disturbance is likely to come from carbon sequestration proposals for conventional coal burning power plants. ${ }^{172}$

To sum up, then, fracturing poses a number of potentially significant risks that are not unique to fracturing, including the competitive threat to renewable energy, air pollution, pressure on local infrastructure, pressure on local water supplies, and induced earthquakes. We assume these problems can be addressed by adapting or expanding existing regulatory systems. All carbon fuels pose a competitive challenge to renewables. All states have departments of transportation regulating the use of local roads by trucks. EPA has regulatory authority over air pollution risks, and all states have systems for dealing with competing claims to groundwater. Earthquake risks, primarily from disposal of spent fluid in injection wells, appear to be small and are similar to the risks associated with other deep injection projects. ${ }^{173}$

\section{NOVEL RISKS OF WATER CONTAMINATION}

Unlike the risks discussed in Part III, the risk of contaminating groundwater is, in important ways, unique to fracturing. It is not surprising that this issue has attracted a great deal of attention from the media and environmental organizations, since groundwater obviously is an essential resource, every bit as important as energy.

This Part describes four different ways that fracturing and horizontal drilling in shale might contaminate groundwater: first, during or after the fracturing itself, fracturing fluid might migrate from the shale seam into water wells and aquifers; second, natural gas released or disturbed by fracturing might seep into water wells and aquifers; third, vibrations from drilling or fracturing might disturb contaminants lying at the bot-

Order Imposing an Immediate Cessation of All Disposal Well Operations and Establishment of a Moratorium Area for Any Class II or Class II Commercial Disposal Wells in a Certain Area, Arkansas Oil and Gas Commission (proposed July 8, 2011).

171. NAT'L RES. COUNCIL, supra note 167 at 13.

172. Id. at 8-9, 89.

173. Although developing a regulatory regime for seismic risks is beyond the scope of this Article, the regulatory strategy proposed here, backstopping best practices rules with liability, could be applied to seismic risks if they prove sufficiently serious to warrant this effort. 
tom of a water well, mixing them into the well water; fourth, used fracturing fluid, or waste products generated by the production of oil and gas, might be disposed of in ways that pollute water wells and aquifers. Unlike the risks described in Part III, at least some of these risks are unlikely to arise in conventional gas drilling or, for that matter, in other industrial and commercial activities. An important challenge for policymakers is that the magnitude of these fracturing-specific risks is uncertain. Although experience so far suggests that the risks are limited, the practice is sufficiently new that definitive conclusions are hard to draw.

In addition, in part because these risks are novel, there is something of a regulatory vacuum for dealing with them. Important provisions of federal law exempt fracturing. ${ }^{174} \mathrm{Oil}$ and gas production are regulated primarily at the state and local level. ${ }^{175}$ States have begun focusing on water contamination issues, but these efforts are currently in progress.

\section{A. FIRST RISK: FraCtURING FLUID}

Fracturing fluid is $99.5 \%$ water and sand, but the other $.5 \%$ currently includes toxic chemicals. ${ }^{176}$ Obviously, we do not want toxic chemicals to seep into water wells and underground aquifers.

Technological advances may reduce the use of toxic chemicals in shale oil and gas drilling. Leaks and spills are less worrisome if new fracturing technologies are developed that do not include toxic chemicals. Halliburton has tested a fracturing fluid that uses enzymes and acids from food, and a senior Halliburton executive attracted media attention by drinking it (in diluted form). ${ }^{177}$ A number of companies are also working on developing "eco-friendly" fracturing fluid. ${ }^{178}$ Others are explor-

174. Wiseman, Untested Waters, supra note 12, at 134-35 (discussing fracturing's exemption from the Safe Water Drinking Act).

175. Id. at 43 .

176. Konigsberg, supra note 15, at 52. Although different companies use different formulas, fracturing fluid could include benzene, ethylbenzene, toluene, boric acid, monoethanolamine, xylene, diesel-range organics, methanol, formaldehyde, hydrochloric acid, ammonium bisulfite, 2-butoxyethanol, and 5chloro-2-methyl-4-isothiazotin-3-one. Bateman, supra note 21.

177. Steve Hargreaves, Clean Fracking: Moving to Replace Chemicals, CNN MONEY (Nov. 16, 2011), http://money.cnn.com/2011/11/16/news/economy/ clean_fracking/index.htm.

178. Joe Carroll, Chesapeake Testing 'Green' Fracking Fluids in Shale Wells, BLOOMBERG NEWS (Oct. 2, 2012 3:23 PM), http://www.bloomberg.com/ news/2012-10-02/chesapeake-testing-green-fracking-fluids-in-u-s-shale-wells 
ing ways to fracture shale without using any water, substituting liquid propane, carbon dioxide, or some other gas. ${ }^{179}$ Hopefully these efforts will be successful. This would alleviate most of the risks associated with transporting water to and from the drilling site. Of course, these techniques may present other risks, and it may still be necessary to inject the production zone with toxic biocides to keep bacteria from degrading the oil and gas. ${ }^{180}$

Therefore, although these advances should prove helpful, they probably will not represent a complete solution, at least in the near term. How likely is it, then, that toxic chemicals used in shale oil and gas drilling will migrate into drinking water? In theory, this could happen in five different ways. We describe each of these five fracking-fluid risks in turn.

\section{First Fracturing Fluid Risk: Migration Through Subsurface Cracks}

The goal of fracturing is to produce cracks in underground shale formations, so gas and oil will come out. One concern is that fracturing fluid might migrate through these cracks into water wells and aquifers. This is "[o]ne of the commonly perceived risks from hydraulic fracturing," a 2011 Department of Energy study observed. ${ }^{181}$

Fortunately, though, geological considerations suggest that this risk is remote. Fracturing in shale beds typically takes place at 5,000 to 10,000 feet, which is one to two miles below the surface, while the water table is typically only 500 to 1,000 feet down. ${ }^{182}$ In between are multiple layers of rock and clay, some of which are highly impermeable. Toxic chemicals would have to migrate upward-against the massive weight of rock

.html; Press Release, Business Wire, New EPA-Aproved Fracking Fluid 100\% Green (Jan. 10, 2012), available at http://www.businesswire.com/news/home/ 20120110005568/en/EPA-Aproved-Fracking-Fluid-100-Green; Press Release, Family Joule Holdings, Eco-Friendly Fracking Fluid Set for Debut (Dec. 6, 2011), available at http://www.prlog.org/11743014-eco-friendly-fracking-fluid -set-for-debut.html (announcing release of nontoxic fracking fluid made from waste tallow from beef processing by Family Joule Holdings, Inc.).

179. Kevin Bullis, Skipping the Water in Fracking, MIT TECH. REV. (Mar. 22, 2013), http://www.technologyreview.com/news/512656/skipping-the-water -in-fracking; Kate Galbraith, Waterless Fracking Makes Headway in Texas, Slowly, NPR (March 27, 2013), http://stateimpact.npr.org/texas/2013/03/27/ waterless-fracking-makes-headway-in-texas-slowly/.

180. EPA 2011 PLAN, supra note 154, at 29.

181. FIRST 2011 DOE REPORT, supra note 10, at 19.

182. 2011 MIT STUDY, supra note 4 , at 40 tbl. 2.4. 
and soil pressing down on the layer of shale being fractured-a mile or more to contaminate groundwater. ${ }^{183}$ It is extremely unlikely that cracks produced on a horizontal plane this far below the surface would produce permeable fissures extending upward thousands of feet, and a study analyzing thousands of fractures in Texas and Pennsylvania shows they have not done so. ${ }^{184}$

Accordingly, a 2011 DOE study "shares the prevailing view that the risk of fracturing fluid leakage into drinking water sources through fractures made in deep shale reservoirs is remote" and observes that "there are few, if any, documented examples of such migration." ${ }^{185}$ A 2011 MIT study co-authored by Ernest Moniz, who became the Secretary of Energy two years later, offers a similar assessment. ${ }^{186}$ Given EPA's estimate that 35,000 U.S. gas wells were fractured in 2006 alon $e^{187}$-and the fact that two million fracturing treatments have been pumped

183. U.S. GEOLOGICAL SURVEY, AQUIFERS (2013), available at http://ga .water.usgs.gov/edu/pdf/earthgwaquifers.pdf ("On the average ... the porosity and permeability of rocks decreases as their depth below land surface increases; the pores and cracks in rocks at great depths are closed or greatly reduced in size because of the weight of overlying rocks.").

184. Fisher, supra note 13 (concluding from fractures mapped in the Barnett Shale in Texas and the Marcellus Shale in Pennsylvania, gathered from over 15,000 fracturing operations, that the data "show the huge distances separating the fracs from the nearest aquifers at their closest points of approach, conclusively demonstrating that hydraulic fractures are not growing into groundwater supplies, and therefore, cannot contaminate them"); see also Konigsberg, supra note 15, at 52 (risk of underground contamination "as close to scientifically impossible as anything can be said to be" (quoting Lynn Helms, chief mineral-resources regulator in North Dakota)).

185. FIRST 2011 DOE REPORT, supra note 10, at 3,19.

186. 2011 MIT STUDY, supra note 4, at 7 ("Shale development requires large-scale fracturing of the shale formation to induce economic production rates. There has been concern that these fractures can also penetrate shallow freshwater zones and contaminate them with fracturing fluid, but there is no evidence that this is occurring."); $i d$. at 40 ("In the studies surveyed, no incidents are reported which conclusively demonstrate contamination of shallow water zones with fracture fluids."); id. app. $2 \mathrm{E}$ at 2 ("It is noteworthy that no incidents of direct invasion of shallow water zones by fracture fluids during the fracturing process have been recorded."). A variation of this concern is that there may be cracks or other pathways-not created by fracturing but occurring naturally-that connect shallow aquifers with shale formations that are much deeper underground. A 2012 study theorizes that naturally occurring brine from the shale can migrate through these pathways up to aquifers. Nathaniel R. Warner et al., Geochemical Evidence for Possible Natural Migration of Marcellus Formation Brine to Shallow Aquifers in Pennsylvania, 109 PROC. NAT'L ACAD. SCI., 11961, 11965 (2012), available at http://www.biology.duke .edu/jackson/pnas2012.pdf.

187. EPA 2011 PLAN, supra note 154 , at 22. 
in the past sixty years ${ }^{188}$ - the paucity of confirmed incidents of water contamination from the underground migration of fracturing fluid provides powerful evidence that the risk is small. Even so, the risk is clearly disturbing to many people, and warrants further study and monitoring as the use of fracturing spreads further.

\section{Second Fracturing Fluid Risk: Surface Spills}

There are other pathways in which fracturing fluid could enter water supplies, each of which presents a more realistic risk. ${ }^{189}$ Fracturing chemicals might be accidentally spilled on the surface--before or after the drilling process-and might then seep down into the water table. ${ }^{190}$ Trucks carrying toxic chemicals, for instance, can be involved in traffic accidents. "There are some legitimate risks to simply getting frack chemicals to the well," North Dakota's chief minerals resources regulator said. "You've got thirty gallons of biohazard at a well site that can be very dangerous in its concentrated form." ${ }^{191}$ Some spills have been reported in the media ${ }^{192}$ although, as EPA has observed, "the frequency and typical causes of these spills remain unclear." ${ }^{\prime 193}$ In posing a risk of surface spills, fracturing resembles other industrial and commercial activities that transport and store toxic chemicals; the chemicals used in fracturing are commonly used in other products, including swimming pool cleaner ( $\mathrm{HCl}$ ), cosmetics, toothpaste and sauces (guar gum), detergents and hair cosmetics (ammonium persulfate, potassium, sodium perosydisulfate), glass cleaner and antiperspirant (isopropanol), and low sodium table salt (potassium

188. Fisher, supra note 13 at 1.

189. See generally Wiseman, supra note 163 (concluding, based on survey of reports of violations of state standards, that the most pressing risks arise not from injection of fracturing fluid underground but from other stages in the well development process and the higher rate of well drilling spurred by fracturing).

190. Surface spills can also pose risks to soil and vegetation. In one experiment, researchers released approximately 300,000 gallons of fracturing fluid in a West Virginia forest. The spill damaged ground vegetation, caused leaves to drop prematurely, and increased the mortality rate of trees. Mary Beth Adams, Land Application of Hydrofracturing Fluids Damages a Deciduous Forest Stand in West Virginia, 40 J. ENVTL. QUALITY 1340, 1341 (2011).

191. Konigsberg, supra note 15, at 52 (quoting Lynn Helms).

192. See, e.g., Abrahm Lustgarten, Frack Fluid Spill in Dimock Contaminates Stream, Killing Fish, PRo PUBLICA (Sept. 21, 2009, 4:09 PM), http://www .propublica.org/article/frack-fluid-spill-in-dimock-contaminates-stream-killing -fish-921.

193. EPA 2012 PROGRESS REPORT, supra note 4, at 31-32. 
chloride) ${ }^{194}$ A range of regulations already govern the risks of such spills, requiring spill prevention plans and rules governing the storage of chemicals. ${ }^{195}$ Of course, by increasing the total volume of toxic chemicals that are transported, fracturing makes this risk more significant. The bottom line, then, is that fracturing fluid needs to be transported and stored carefully.

\section{Third Fracturing Fluid Risk: Flow-Back and Produced Water}

When shale cracks, the gas that is released pushes some fluid back up to the surface. Some of this is used fracturing fluid, which is called "flow-back." ${ }^{\prime 196}$ In addition, water that had accumulated naturally in the shale formation, called "produced water," is also pushed up. ${ }^{197}$ Although it does not contain toxic fracturing chemicals, produced water has natural contaminants, including salt, other organic compounds, silt, clay, oil, grease, and naturally occurring radioactive material. ${ }^{198}$ Energy companies have to catch this fluid when it comes up, so it does not seep down into the water table.

\section{Fourth Fracturing Fluid Risk: Cracked Well Casings}

There is a risk that the well itself might crack at or above the water table, allowing fluid to leak into nearby wells or aquifers. ${ }^{199}$ If there is a crack in the well casing (the layers of steel and concrete encasing the well), then what is inside the wellbore-whether it is fracturing fluid, gas, or oil-could leak out. As a result, it is essential for the concrete in the well casing to set properly, and for the casing to be thick and deep enough to prevent leaks near the water table. The need for effective well

194. 2011 MIT STUDY, supra note 4, at 42; see also EPA 2012 PROGRESS REPORT, supra note 4, at 30 ("[S]ome of the chemicals commonly used in hydraulic fracturing fluid are ubiquitous ....").

195. Benincasa, supra note 11 , at 9 (describing current law governing surface activities).

196. FIRST 2011 DOE REPORT, supra note 10, at 21.

197. Id.

198. U.S. GEOLOGICAL SURVEY, NATURALly OCCURRING RADIOACTIVE MA. TERIALS (NORM) IN PRODUCED WATER AND OIL-FIELD EQUIPMENT-AN ISSUE FOR THE ENERGY INDUSTRY (1999), available at http://pubs.usgs.gov/fs/fs -0142-99/fs-0142-99.pdf (finding that produced water can bring to the surface radium that comes from the shale deep underground).

199. See FiRST 2011 DOE REPORT, supra note 10, at 19. 
casings is familiar to state oil and gas regulators, since it is essential in conventional drilling as well. ${ }^{200}$

\section{Fifth Fracturing Fluid Risk: Blowouts}

There can be a blowout-an uncontrolled release of gas or fluid inside the well, in effect, a "gusher"-either at the surface or inside the well. This can happen when energy companies encounter an unexpected level of pressure (e.g., a pocket of gas). For example, three blowouts at Pennsylvania gas wells-two operated by Chesapeake Energy and one by EOG Resources Inc.-led to surface spills and attracted national media attention. ${ }^{201}$ Blowouts are a familiar risk to be managed in conven-

200. Id. at 20 (" $[\mathrm{A}]$ well with poorly cemented casing could potentially leak, regardless of whether the well has been hydraulically fractured."); Benincasa, supra note 11, at 9 ("It should first be noted that the states have always had well design, construction, and cementing standards to protect USDW [underground sources of drinking water] that are encountered during drilling operations. The states also have existing casing requirements to ensure that fluids injected into the well and removed from the well are isolated from USDW."); see also, e.g., 2 COLO. CODE REGS. § 404-1, RULES 308(a), 317(g)-(h) (2013) (Colorado requires casing to fifty feet and set "in a manner sufficient to protect all fresh water and to ensure against blowouts or uncontrolled flows," minimum psi, and copies of "all logs run"); N.D. ADMIN. CODE 43-02-03-21, 31 (2013) (North Dakota requires casing "at sufficient depths to adequately protect and isolate all formations containing water, oil, or gas or any combination of these," new or pressure tested pipe, and bond logs); N.Y. DEP'T OF ENVTL. Conservation, Mitigation MEasures CH. 7 \$ 7.1.4.2-3, ReVISED DRAFT SUPPLEMENTAL GENERIC ENVIRONMENTAL IMPACT STATEMENT (2011) (N.Y. requires casing to seventy-five feet or into bedrock, whichever is deeper, new or pressure tested pipe, and bond logs); 25 PA. CODE § 78.83-85 (2013) (Pennsylvania requires casing to fifty feet or into consolidated rock, whichever is deeper, with internal pressure rating "that is at least $20 \%$ greater than the anticipated maximum pressure," cement that meets minimum specified standards, and cement bond logs).

201. See Susan Phillips, Bradford County Blow-out Costs Chesapeake More Than $\$ 250 k$, NPR STATE IMPACT (Feb. 9, 2012, 5:43PM), http://stateimpact .npr.org/pennsylvania/2012/02/09/bradford-county-blow-out-costs-chesapeake -more-than-200000/; Mike Soraghan, PA Well Blowout Tests Natural Gas Industry on Voluntary Fracking Disclosure, N.Y. TIMES, May 4, 2011, http:// www.nytimes.com/gwire/2011/05/04/04greenwire-pa-well-blowout-tests

-natural-gas-industry-on-36297.html; Mark Long \& Jason Womack, Blowout Occurs at Pennsylvania Gas Well, WaLL ST. J., June 4, 2010, http://online.wsj .com/article/SB10001424052748704764404575286910201269800.html; Lisa J. Molofsky et al., Evaluation of Methane Sources in Groundwater in Northeastern Pennsylvania, 51 GROUNDWATER 333, 333 (May-June 2013) ("[O]ur assessment of isotopic and molecular analyses of hydrocarbon gases in Dimock Township suggests that gases present in local water wells are most consistent with Middle and Upper Devonian gases sampled in the annular spaces of local gas wells, as opposed to Marcellus Production gas."). 
tional drilling; they usually can be prevented with thick and deep casing, as well as with so-called blowout preventers. ${ }^{202}$

\section{Studies on the Magnitude of These Fracking-Fluid Risks}

The magnitude of all these risks is uncertain and highly contested. A number of recent lawsuits have alleged water contamination from fracturing. ${ }^{203}$ For example, residents in Dimock Township, Pennsylvania claimed their water turned brown because of fracturing. However, EPA later surveyed their groundwater and concluded that it was safe, and a subsequent academic study concluded that the methane in Dimock water was naturally occurring "with no necessary contribution from deeper Marcellus shale gas." ${ }^{204}$ The Dimock lawsuit, which was covered prominently in Vanity Fair and other media outlets, ${ }^{205}$ settled (with confidential terms) in August 2012. ${ }^{206} \mathrm{~A}$ range of other allegations has been publicized widely, ${ }^{207}$ including claims about potential effects of fracturing on livestock and the food supply. ${ }^{208}$ Parties in fracturing-related litigation have

202. Some states offer detailed and specific requirements governing blowout prevention, while others have more general requirements. See, e.g., ARK. OIL \& GAS COMMISSION GENERAL RULES AND REGULATIONS, R. B-16 (2013) (establishing a general requirement to take "[a]ll proper and necessary precautions . . . for keeping the well under control . . . including but not limited to the use of blow-out preventers"); MONT. ADMIN. R. 36.22.1014 (2013) (detailing blowout prevention regulations).

203. See, e.g., Fiorentino v. Cabot Oil \& Gas Corp., 750 F. Supp. 2d 506, 508 (M.D. Pa. 2010); Tucker v. S.W. Energy Co., 1:11-CV-44-DPM, 2012 WL 528253, at *1 (E.D. Ark. Feb. 17, 2012).

204. Molofsky et al., supra note 201, at 345.

205. See Bateman, supra note 21; see also Michael Rubinkam, Dimock, PA Water Tests Conducted by EPA Amid Fracking Concerns, HUFFINGTON POST (July 25, 2012, 9:10 PM), http://www.huffingtonpost.com/2012/07/25/dimock -pa-water_n_1702992.html.

206. Michael Rubinkam, Pa. Drilling Town Agrees to Settlement in Fracking Federal Lawsuit, CHRISTIAN SCI. MONITOR (Aug. 15, 2012), http:// www.csmonitor.com/USA/Latest-News-Wries/2012/0815/Pa.-drilling-town -agrees-to-settle-in-fracking-federal-lawsuit.html.

207. McKay et al., supra note 139 , at 126 ("Media reports of landowner complaints alleging problems with drinking water wells due to nearby Marcellus Shale operations abound.").

208. Michelle Bamberger \& Robert E. Oswald, Impacts of Gas Drilling on Human and Animal Health, 22 NEw SOLUTIONS 51, 55-59 (2012) (identifying illnesses in animals based on anonymous interviews with landowners near drilling sites and their veterinarians); Elizabeth Royte, Fracking our Food Supply, THE NATION (Nov. 28, 2012), http://www.thenation.com/article/ 171504/fracking-our-food-supply\#.html (describing concerns that fracking may cause human health effects through the food supply). 
testified before Congress. ${ }^{209}$ Popular and documentary films have highlighted environmental concerns about fracturing, ${ }^{210}$ and celebrities have taken an interest in the issue. ${ }^{21}$ Overall, media coverage has been quite negative. ${ }^{212}$ There is also evidence that concerns about groundwater contamination from fracturing have affected residential real estate prices. ${ }^{213}$

209. Wiseman, Untested Waters, supra note 12, at 138 ; see also RUTH Wood et al., The Tyndall Centre for Climate Change, Shale Gas: A Provisional Assessment of Climate Change and Environmental IMPACTS 5 (2011), available at http://www.scribd.com/doc/55017665/The-Tyndall -Report-on-Fracking ("There is considerable anecdotal evidence from the US that contamination of both ground and surface water has occurred in a range of cases."); Robert W. Howarth, Statement for the EPA Hydraulic Fracturing Public Informational Meeting (Sep. 15, 2010), available at http://cce .cornell.edu/EnergyClimateChange/NaturalGasDev/Documents/PDFs/

Howarth\%20statement\%20to\%20EPA\%-20\%2015\%20Sept\%20\%202010.pdf ("Shale gas development clearly has the potential to contaminate surficial groundwater with methane, as shown by the large number of incidences of explosions and contaminated wells in Pennsylvania, Wyoming, and Ohio in recent years.").

210. See A.O. Scott, Deep Down, He Wants to Help, N.Y. TIMES, Dec. 28, 2012, at C1 (reviewing Promised Land with Matt Damon and describing its "polemical intentions"); see also GAS LAND (Josh Fox, 2010) (documentary film critical of fracturing).

211. See, e.g., Daniel Gilbert, Matt Damon Fracking Film Lights Up Petroleum Lobby, WALL ST. J., Oct. 8, 2012, at B1; Alex Katz, Yoko Ono's AntiFracturing Coalition Includes Lady Gaga and . . . Paul McCartney?, HUFFINGTON POST (Aug. 29, 2012, 2:38 PM), http:/www.huffingtonpost.com/ 2012/08/29/yoko-onos-anti-fracturing_n_1841291.html.

212. According to one study, out of 444 newspaper articles discussing fracturing, $288(65 \%)$ were negative, $103(23 \%)$ were neutral, and only $53(12 \%)$ were positive. Charles G. Groat \& Thomas W. Grimshaw, ThE UnIV. OF TEX. AT AUSTIN ENERGY INSTITUTE, FACT-BASED REGULATION FOR ENVIRONMENTAL PROTECTION IN SHALE GAS DEVELOPMENT 13-14 (2012), available at http://www.ourenergypolicy.org/wp-content/uploads/2012/05/ei_shale_gas regulation 120215.pdf. TV coverage was even more negative. Of $224 \mathrm{TV}$ segments, $152(68 \%)$ were negative, $55(25 \%)$ were neutral, and $17(8 \%)$ were positive. Finally, of 311 online stories, $197(63 \%)$ were negative, $92(30 \%)$ were neutral, and $22(7 \%)$ were positive. Id. This study was part of a broader report authored by the University of Texas Energy Institute, which was withdrawn based on a finding that the report's principal investigator had a conflict of interest that he had not disclosed in the report. Jim Efstathiou Jr. \& Mark Drajem, Texas Energy Institute Head Quits Amid Fracking Study Conflicts, BLOOMBERG NEwS (Dec. 6, 2012, 3:43 PM), http://www.bloomberg.com/news/ 2012-12-06/texas-energy-institute-head-quits-amid-fracking-study-conflicts .html.

213. See Muehlenbachs et al., supra note 4, at 29 (finding that among Washington, PA houses near drilling sites, those that depend on groundwater sell at a discount compared to comparable houses that use water piped in from municipal sources). 
Yet according to a number of studies, after thousands of wells have been fractured in shale beds, there are no documented cases in which fracturing fluid has migrated into aquifers during the fracturing process. ${ }^{214}$ Surface spills are more of an issue, as is methane contamination, which is discussed below. ${ }^{215} \mathrm{~A} 1998$ study by an association of state regulators known as the Groundwater Protection Council-which focused on fracturing in coal beds, since fracturing in shale was not yet widespread-found only one complaint of groundwater contamination and concluded that it was unsubstantiated. ${ }^{216}$

EPA did a study in 2004-again, of coal beds instead of shale-surveying 200 peer review studies, and interviewing fifty state and local employees as well as approximately forty people who complained of water contamination. ${ }^{217}$ It found "no confirmed cases [of groundwater well contamination] that are linked to fracturing fluid injection into CBM [coal bed methane] wells or subsequent underground movement of fracturing fluids." ${ }^{218}$ Further, although thousands of CBM wells are fractured annually, EPA did not find confirmed evidence that drinking water wells have been contaminated "by hydraulic fracturing fluid injection into CBM wells."

214. See, e.g., EPA 2012 PROGRESS REPORT, supra note 4, at 127-37; EPA 2011 PLAN, supra note 154, at 37-40; Konigsberg, supra note 15, at 46-47; Wiseman, supra note 163, at 123.

215. See supra Part IV.A.2.

216. GROUNDWATER PROTECTION COUNCIL, SuRVEY RESUlts ON INVENTORY AND EXTENT OF HYDRAULIC FRACTURING IN COALBED METHANE WELLS IN THE PRODUCING STATES 9 (1998).

217. McKay et al., supra note 139 , at 135 .

218. EPA, EVALUATION OF IMPACTS TO UNDERGROUND SOURCES OF DRINKING WATER BY HYDRAULIC FRACTURING OF COALBED METHANE RESERVOIRS, NATIONAL STUDY FINAL REPORT 2 (2004), available at http://www.epa.gov/ safewater/uic/pdfs/cbmstudyattachuic-final-factsheet.pdf.

219. OFFICE OF GROUNDWATER \& DRINKING WATER, EPA, EVALUATION OF IMPACTS TO UNDERGROUND SOURCES OF DRINKING WATER BY HYDRAULIC FRACTURING OF COALBED METHANE RESERVOIRS: NATIONAL STUDY FINAL REPORT ES-13 (2004). EPA went onto say that "[b]ased on the information collected and reviewed, EPA has determined that the injection of hydraulic fracturing fluids into CBM [coalbed methane wells] poses little or no threat to ESDWs [underground sources of drinking water]. Continued investigation is not warranted at this time." Id. at ES-16. This study has been criticized on the grounds that an analysis of coalbeds may not apply to shale. Leonard S. Rubin, Note, Frack to the Future: Considering a Strict Liability Standard for $\mathrm{Hy}$ draulic Fracturing Activities, 3 J. ENERGY \& ENVTL. L. 117, 120 (2012). But see Wiseman, Untested Waters, supra note 12, at 140-41 (noting that coal is probably riskier than shale, which is farther underground). An EPA employee also charged that the study "appear[ed] to have a conflict-of-interest" because the panel included three industry experts and two former employees of oil 
In addition, a 2009 survey of state regulators did not identify any verified case of water contamination from fracturing. ${ }^{220}$ Two years later, the Groundwater Protection Council commissioned a study of fracturing in Texas and Ohio. According to the study, between 1993 and 2008, 16,000 shale gas wells were drilled in Texas, and after investigating 211 incidents of water contamination, the Texas Railroad Commission did not identify a single ground water contamination incident resulting from site preparation, drilling, well construction, completion, hydraulic fracturing stimulation, or protection operation. ${ }^{221}$ The study drew the same conclusion about the 185 incidents investigated in Ohio between 1983 and 2007. ${ }^{222}$

The 2011 MIT study co-authored by Ernest Moniz identified forty-three incidents related to gas-well drilling, based on its survey of the literature. ${ }^{223}$ Fourteen were surface spills, while most of the others involved methane contamination. ${ }^{24}$ "It is noteworthy," the MIT study says, "that no incidents of direct invasion of shallow water zones by fracture fluids during the fracturing process have been recorded."225

Likewise, the Department of Energy injected fracturing fluid that contained tracer chemicals in a Pennsylvania drilling site that was 8000 feet below the surface. After years of monitoring, they reported in 2013 that no tracer chemicals had been detected in a monitoring zone above this drilling site (which was itself 3000 feet below the surface). ${ }^{226}$

companies. Letter from Weston Wilson, EPA Employee, to Wayne Alard \& Ben Nighthorse Campbell, then serving U.S. Senators, and Diana DeGette, U.S. House Rep. (Oct. 8, 2004), available at http://www.latimes.com/media/acrobat/ 2004-10/14647025.pdf; see also Wiseman, Untested Waters, supra note 12, at 173 (claiming that there was no evidence that the experts were in fact biased, as opposed to manifesting an appearance of bias).

220. McKay et al., supra note 139, at 135-36 \& n.61 (discussing a 2009 survey conducted by the Interstate Oil and Gas Compact Commission of state regulators).

221. Scott Kell, The Groundwater Protection Council, State Oil AND GAS AGENCY GROUNDWATER INVESTIGATIONS AND THEIR ROLE IN ADvancing Regulatory Reforms: A Two Stage Review: OHIO and TeXas 2 (2011).

222. Id.

223. 2011 MIT STUDY, supra note 4 , at 39.

224. Id.

225. Id. at app. $2 \mathrm{E}$ at 2 ; id. at $39-40$.

226. Kevin Begos, DOE Study: Fracking Chemicals Didn't Taint Water, USA TODAY, July 19, 2013, http://www.usatoday.com/story/money/business/ 2013/07/19/doc-study-fracking-didn't-taint/2567721/. 
So far, only one government study has concluded that "the data indicates likely impact to groundwater that can be explained by hydraulic fracturing." ${ }^{227}$ In December 2011, EPA released a draft study of water contamination in Pavillion, Wyoming, finding methane, benzene, and other organic compounds. Yet, as the study pointed out, the gas wells in Pavillion are unusually shallow-at 1,000 to 1,500 feet, instead of 5000 to 10,000 feet. ${ }^{228}$ As a result, the findings are not representative, as EPA itself emphasized: "[ $t]$ he draft findings announced today are specific to Pavillion, where the fracturing is taking place in and below the drinking water aquifer and in close proximity to drinking water wells-production conditions different from those in many other areas of the country."229 In addition, EPA did not find contamination in drinking water wellswhich complied with safety standards. ${ }^{230}$ Rather, they found contamination in deeper monitoring wells that were dug specifically for the study. ${ }^{231}$ Moreover, the owner of the natural gas wells in Pavillion responded that U.S. geological surveys from as early as the 1880 s have documented the poor quality of groundwater in Pavillion. ${ }^{232}$ It may be, therefore, that contaminants found by EPA occur naturally in the water (e.g., because natural gas is so close to the surface $)^{233}$ or derive from "legacy pits" (i.e., old wells that predate fracturing). ${ }^{234}$

227. EPA, OFFICE OF RESEARCH AND DEV., DRAFT: INVESTIGATION OF GROUND WATER CONTAMINATION NEAR PAVILLION, WYOMING xiii (2011).

228. Id. at 33 .

229. Press Release, EPA, EPA Releases Draft Findings of Pavillion, Wyoming Ground Water Investigation for Public Comment and Independent Scientific Review, (Dec. 8, 2011), available at http://yosemite.epa.gov/opa/ admpress.nsf/D/EF35BD26A80D6CE3852579600065C94E.

230. Id. ("Detections in drinking water wells are generally below established health and safety standards.").

231. Id.

232. Press Release, Encana Corp.,Why Encana Refutes U.S. EPA Pavillion Groundwater Report, (Dec. 12, 2011), http://www.encana.com/news-stories/ news-releases/details.html?release $=632327$.

233. See Mead Gruver, Encana Mounts Response to EPA Fracking Report, BLOOMBERG BUS. WEEK. (Dec. 21, 2011, 10:48AM), http://www.businessweek .com/op/financialnews/D9ROVVB00.htm.

234. See Jeffrey Folks, The EPA's Unconscionable War on Fracking, AMERICAN THINKER (Dec. 21, 2011), http://www.americanthinker.com/2011/12 the_epas_unconscionable_war_on_fracking.html; The EPA's Fracking Scare, WALL ST. J., Dec. 19, 2011, at A18. 
EPA is currently conducting a more comprehensive study of the risks to groundwater. Hopefully this study will shed further light on these issues. ${ }^{235}$

\section{B. SECOND RISK: CONTAMINATION OF WATER WELLS WITH METHANE}

In addition to fracturing fluid and produced water, the natural gas itself-which is predominantly methane--can also contaminate groundwater. This is a more significant risk than the migration of fracturing fluid, and there have been reported incidents of methane contamination in fractured wells-and, for that matter, also in conventionally drilled gas wells. ${ }^{236}$ Indeed, methane contamination is an old problem, which is not unique to fracturing. Since methane can leak out through cracks in vertical well pipes that pass through aquifers, the most effective response is for states to regulate the thickness and depth of well casings, something they already do ${ }^{237}$ For example, Texas enacted legislation updating its well casing regulations in $2013{ }^{238}$ In addition, old wells, which predate fracturing and horizontal drilling, also can leak if not sealed properly. The novel risk presented by fracturing is the possibility that methane might migrate from the fractured shale seam through

235. See generally EPA 2012 PROGRESS REPORT, supra note 4.

236. 2011 MIT STUDY, supra note 4, at 7 (noting that although there is no evidence of the migration of fracking fluid, "[t]here is, however, evidence of natural gas migration into freshwater zones in some areas"); $i d$. at app. 2E at 2 (noting that approximately half of forty-three documented instances of water contamination from oil and gas drilling in their survey of literature are from methane contamination, mostly from cracks in well casing); FIRST 2011 DOE STUDY, supra note 10 , at 20 ("Methane leakage from producing wells into surrounding drinking water wells . . . is a greater source of concern than the leakage of fracking fluid]."); see also GROUNDWATER PROTECTION COUNCIL, supra note 216 , at 10 (finding no proven incidents of underground water pollution from methane).

237. See 2011 MIT STUDY, supra note 4, at 41 ("The protection of groundwater aquifers is one of the primary objectives of state regulatory programs, and it should be emphasized that good oil field practice, governed by existing regulations, should provide an adequate level of protection from [methane leaks]."); Benincasa, supra note 11, at 9 ("It should first be noted that the states have always had well design, construction, and cementing standards to protect USDW [underground sources of drinking water] that are encountered during drilling operations. The states also have existing casing requirements to ensure that fluids injected into the well and removed from the well are isolated from USDW.").

238. Railroad Commission Today Adopts Amendments to Oil \& Gas Well Construction Rules, R.R. COMM'N OF TEX. (May 24, 2013), http://www.rrc.state .tx.us/pressreleases/2013/052413.php. 
pre-existing fissures in the overlying rock-or fissures created or enlarged by fracturing-into aquifers above or near the seam.

The mere presence of methane in water wells, though, does not establish that this methane contamination was caused by fracturing. Some methane contamination occurs naturally, since shallow methane deposits sometimes migrate up into the water table on their own. ${ }^{239}$ For example, a U.S. Geological survey in forty-seven counties in West Virginia, which was conducted before shale gas drilling took place there (from 1997 through 2005), found methane in 131 out of the 170 residential wells that they tested. ${ }^{240}$ Likewise, a 2011 study establishing baseline levels of contamination in Pennsylvania before shale gas drilling began found methane contamination in $40 \%$ of wells. ${ }^{241}$ The study then compared levels of contamination after the drilling, and found no statistically significant difference; likewise, a 2013 study found methane in $78 \%$ of water samples taken in Pennsylvania before drilling began, and noted historical evidence of "flammable effervescing springs and water wells dating back to the late 1700s."242 Although a 2011 academic study claims to find a link between drilling and methane contamination-by showing that there is more methane in Pennsylvania water wells that are within a kilometer of active drilling than in those that are more than a kilometer away ${ }^{243}$ - the study did not do baseline testing to establish that the wells had

239. FIRST 2011 DOE REPORT, supra note 10, at 20 ("The presence of methane in wells surrounding a shale gas production sight is not ipso facto evidence of methane leakage from the fractured producing well since methane may be present in surrounding shallow methane deposits or the result of past conventional drilling activity.").

240. U.S. GeOlogical SuRVEY, METHaNe IN WEST Virginia Ground WATER 1 (2006), available at http://pubs.usgs.gov/fs/2006/3011/pdf/ Factsheet2006_3011.pdf.

241. Elizabeth W. BoYer et al., The Center for RuRal Pennsylvania, THE IMPACT OF MARCELLUS GAS DRILLING ON RURAL DRINKING WATER SUPPLIES 12 (2011), available at http://www.rural.palegislature.us/documents/ reports/Marcellus_and_drinking_water_2011_rev.pdf.

242. Id. at 4 (" $[\mathrm{S}]$ tatistical analyses of post-drilling versus pre-drilling water chemistry did not suggest major influences from gas well drilling or hydrofracturing (fracking) on nearby water wells, when considering changes in potential pollutants that are most prominent in drilling waste fluids" and "no statistically significant increases in methane levels [were found] after drilling ...."); Molofsky et al., supra note 201, at 336, 345 .

243. Stephen G. Osborn et al., Methane Contamination of Drinking Water Accompanying Gas-Well Drilling and Hydraulic Fracturing, 108 PROC. NAT'L ACAD. SCI. 8172, 8172 (2011) (claiming to "document systemic evidence for methane contamination"). 
less methane before the drilling. It is to be expected, after all, that companies would drill where there is more methane in the ground (and therefore, perhaps, in the water). The study also does not find any chemicals from fracturing fluid in the wells, which one might expect to be present if fracturing-as opposed to natural migration-is the source of this methane. ${ }^{244}$ In response, therefore, a 2013 study concluded that the presence of methane in water correlates better with topography than with shale gas production-it is more common in valleys and low areas-so that "the use of hydraulic fracturing for shale gas in northeastern Pennsylvania has not resulted in widespread gas migration into the shallow subsurface. ${ }^{245}$

\section{THIRD RISK: Disturbance OF SLUdge OR OTHER RESIDUES IN WELLS DUE TO FRACTURING}

A third source of water contamination comes from vibrations and pressure pulses caused by fracturing. Like a spoon stirring a glass of milk with chocolate syrup in the bottom, fracturing can bring iron, manganese, and other contaminants up from the bottom of the well into the water. ${ }^{246}$ This theory may explain why some water wells near drilling sites appear dirty but do not include fracturing chemicals. It is also consistent with studies comparing water quality before and after fracturing that find no change except for increases in manganese and iron. ${ }^{247} \mathrm{~A}$ key aspect of this risk is that the contaminants are $a l$ ready in the well. Residential wells are often dirtier than their

244. In light of the methodological limitations in the Osborn 2011 study, Samuel Schon, a geologist at Brown, concludes that " $[t]$ he data presented simply do not support the interpretation put forth that shale-gas development is leading to methane migration from the Marcellus into shallow groundwater. These data especially do not justify coauthors' reports in the popular press about the process of hydraulic fracturing." Samuel C. Schon, Hydraulic Fracturing Not Responsible for Methane Migration, PROC. OF THE NAT'L ACAD. SCI. (Aug. 30, 2011), http://www.pnas.org/content/early/2011/08/25/1107960108 .full.pdf (citing Rob Jackson \& Avner Vengosh, Strong Evidence that Shale Drilling is Risky, PHILADELPHIA INQUIRER, May 10, 2011, http://articles.philly .com/2011-05-10/news/29528421_1_water-wells-safe-drinking-natural-gas).

245. Molofsky et al., supra note 201, at 345 .

246. COlO. OIL \& GAS CONSERVATION COMM'N, WRITTEN TESTIMONY OF IAN DUNCAN 2, available at http://cogcc.state.co.us/RR_HF2012/Groundwater/ Presentations/DuncanTestimony.pdf (positing that "possible perturbation by pressure waves associated with drilling and completion activities that can lead to false positives").

247. See BOYER ET AL., supra note 241 , at 4 (comparing water wells before and after fracturing, and finding no change in methane, but finding increases in sediment and iron in water). 
owners realize. For example, a recent Pennsylvania survey found that only $16 \%$ of rural wells have a sealed sanitary well cap, while more than half were near septic tanks that had not been pumped with sufficient regularity (if at all) ${ }^{248}$ While fracturing can stir up contaminants that are already in a water well, other activities can as well, such as running multiple faucets at once. ${ }^{249}$

\section{Fourth Risk: Fracturing WASTE AND PRODUCED WATER- INJECTION WELLS AND SEWAGE FACILITIES}

Once fracturing fluid has been used, energy companies need to dispose of it. They also need to dispose of produced water, which is a byproduct of all oil and gas production. It is extremely important to dispose of this waste properly. ${ }^{250}$ Some methods are risky, while others are safe. The worst methodso-called land application, in which the fluid is simply poured onto the ground-creates a meaningful risk that the fluid will seep down into the water table; this practice should be (and generally is) prohibited. ${ }^{251}$ The fluid may also be trucked to a waste treatment facility. If all the facility does is to dilute it and then release it into a body of water-as occurred in Pennsylvania before this practice was stopped-there is a risk of wa-

248. BRyAN R. SWISTOCK ET AL., THE CTR. FOR RURAL PA., DRINKING WATER QUALITY IN RURAL PENNSYlvaNIA AND THE EFFECT OF MANAgEMENT PRACTICES 9, 11 (2009), available at http:/www.rural.palegislature.us/ drinking_water_quality.pdf (noting that although septic tank should be pumped every two to four years to avoid contamination of water wells, $28 \%$ of the 625 wells in the survey with on-lot septic systems were never pumped, while $33 \%$ were pumped less frequently than every four years).

249. Mark Eisner, Separating Fact from Fiction: Careful Hydrogeologic Evaluation May Protect Against Unfair and Baseless Domestic Supply Impact Allegations, Remarks at the AIPG Marcellus Shale: Energy Development and Enhancement by Hydraulic Fracturing Conference (May 5, 2011), available at $\mathrm{http} / /$ www.aipg.org/Seminars/HFMS/Eisner,\%20Mark.pdf (showing elevated turbidity correlated only with domestic use fluctuations).

250. See Daniel J. Rozell \& Sheldon J. Reaven, Water Pollution Risk Associated with Natural Gas Extraction from the Marcellus Shale, 32 RISK ANALYSIS 1382, 1391 (2012) (using probability bounds analysis to conclude that "epistemic uncertainty was largest for wastewater disposal," as opposed to four other potential pathways of water contamination: transportation spills, well casing leaks, leaks through fractured rock, and drilling site surface discharge).

251. FIRST 2011 DOE REPORT, supra note 10, at 21 (noting that surface runoff is forbidden). In March 2011, a company in Pennsylvania was charged with illegally dumping fracturing wastewater on land from 2003 to 2009 . Fracking and Water Pollution, SouRCEWATCH, http://www.sourcewatch.org/ index.php/Fracking_ and_water_pollution (last visted Oct. 17, 2013). 
ter contamination, since the fluid is unlikely to be diluted to the point where it is no longer toxic. ${ }^{252}$

More sophisticated treatment processes do not present this risk. It has become increasingly common for used fracturing fluid to be recycled, as noted above, ${ }^{253}$ which is helpful in minimizing the total volume created. Another practice is to store used fluid and produced water deep underground in so-called injection wells drilled for this purpose and regulated by EPA. ${ }^{254}$ To ensure that injection wells do not pose a risk to the water table, their well casings need to be sufficiently thick and deep, and the well itself should be deep enough so the waste is far below the water table. The issues here are similar to those presented by proposals to inject carbon dioxide from coal-burning power plants into deep geological fissures (so-called carbon sequestration). ${ }^{255}$

252. See Renee Schoof, As Shale Fracturing Booms, Environmental Protection Lags, MCCLATCHY NEWSPAPERS (Dec. 21, 2011), http://www.mcclatchydc .com/2011/12/21/133807/as-shale-fracking-booms-environmental.html\#

.Uh9qQxtOOsp; Sheila M. Olmstead et al., Shale Gas Development Impacts on Surface Water Quality in Pennsylvania, PROC. NAT'L ACAD. SCI. 4962, 4966 (2013) (finding that drilling does not increase presence of chlorides in surface water, but that treatment and release of wastewater from waste treatment facilities does increase chloride levels). For instance, a study of water downstream from a Pennsylvania plant that used to treat fracturing wastewater found elevated levels of radioactivity, salts and metals. Nathaniel R. Warner et al., Impacts of Shale Gas Wastewater Disposal on Water Quality in Western Pennsylvania, ENV. SCIENCE \& TECH. (2013) ("Overall we show that treatment in Josephine Brine Treatment Facility reduces the concentrations of some elements before releasing them into the stream, but wastewater discharge nevertheless reduces the quality of downstream surface water and sediments."). Critics of this study note that the facility has not been used by members of the Marcellus Shale Coalition since May 2011, and that radium levels were below industrial discharge limits. Katie Brown, Five Facts About Duke's Latest AntiShale Study, Energy In Depth, ENERGY IN DEPTH (last visited Oct. 7, 2013), http://energyindepth.org/marcellus/five-facts-about-dukes

-latest-anti-shale-study/.

253. See Bell, supra note 165.

254. 2011 MIT STUDY, supra note 4, at 43 ("The optimum method for disposal of oil field wastewater is injection into a deep saline aquifer through an EPA regulated Underground Injection Control (UIC) water disposal well.").

255. See Alexandra B. Klass \& Elizabeth J. Wilson, Climate Change and Carbon Sequestration: Assessing a Liability Regime for Long-Term Storage of Carbon Dioxide, 58 EMORY L.J. 103, 115-19 (2008). 


\section{E. The Existing REgULATORY REgime}

\section{State and Local Law}

Since fracturing and horizontal drilling in shale beds are relatively new practices, it is not surprising that regulatory regimes governing them are not fully developed. Since the goal of this Article is to propose a regulatory response to the risk of water contamination, we should first offer a brief overview of current law.

Historically, states have been the principal regulators of oil and gas. ${ }^{256}$ As a result, the risk that fracturing could contaminate water is regulated primarily at the state level. ${ }^{257}$ Obviously, tort liability is potentially applicable, although few cases have been decided thus far, so it is unclear how key doctrines will evolve. ${ }^{258}$

In addition, every oil-and gas-producing state has an oil and gas commission. ${ }^{259}$ These commissions require energy companies to file an Application for Permission to Drill (APD) before sinking an oil or gas well. Through this APD authority, state agencies enforce pooling requirements, unitization requirements, well spacing requirements, and so forth. ${ }^{260}$

States also enforce regulations targeting environmental harms, including, increasingly, regulations specific to fracturing. ${ }^{261}$ In some states, such as Pennsylvania and New York,

256. David B. Spence, Federalism, Regulatory Lags, and the Political Economy of Energy Production, 161 U. PA. L. REV. 431, 477 (2012).

257. See id.

258. For a discussion, see infra Part VII.B. See also Thomas E. Kurth et al., American Law and Jurisprudence of Fracing-2012, 58 ROCKY MOUNTAIN MIN. L. FouND. 1, 56-62, available at http://www.haynesboone.com/american -law-and-jurisprudence-on-fracing-2012/ (citing dozens of complaints, but no reported opinions on the merits); Rubin, supra note 219, at 123-25 (considering application of precedents on subsurface trespass, nuisance, negligence, and strict liability to fracturing).

259. A complete listing of state oil and gas commissions can be found on the website of the Texas Railroad Commission, which serves as the oil and gas commission for Texas. Oil and Gas Related Web Addresses, R.R. COMM'N OF TEX., http://www.rrc.state.tx.us/links/statewebadd.php (last visited Oct. 17, 2013).

260. For a general discussion of state and local rules on permission to drill, see Robert H. Freilich \& Neil M. Popowitz, Oil and Gas Fracking: State and Federal Regulation Does Not Preempt Needed Local Government Regulation, 44 URB. LAW. 533, 542-56 (2012).

261. For a very useful summary of recent regulatory activity in eighteen states that have adopted statutes or regulations directed at fracturing, see Kurth et al., supra note 258, at 64-157. 
these environmental harms are regulated by the state department of environmental protection. ${ }^{262}$ Thus, state commissions regulate the strength and depth of well casings and require blowout preventers. ${ }^{263}$ They also require a minimum distance between well pads or particular drilling activities and bodies of water-and these distances vary by state ${ }^{264}$-while others apply these so-called "minimum setback" requirements also to schools, property lines, etc. ${ }^{265}$ Colorado has a tiered regulatory system: drilling that is closer to water and other sensitive areas is subject to more exacting restrictions. ${ }^{266}$ States also have rules seeking to prevent and contain surface spills (e.g. with walls and steel tanks), ${ }^{267}$ and requiring leaks to be reported. ${ }^{268}$ In addition, states regulate the disposal of fracturing waste in various ways. ${ }^{269}$ Many jurisdictions also require energy companies

262. Id.

263. For a discussion of different state approaches to these issues along with citations, see supra notes 200 and 202 and accompanying text.

264. For example, Texas generally does not have a setback requirement. See 16 TEX. ADMIN. CODE $\S 3.37$ (2012) (providing well spacing requirements but no setback requirements). New York's proposed regulations specify minimum distances from bodies of water, including 500 feet from private wells, 2000 feet from public reservoirs, and 4000 feet from unfiltered watersheds. N.Y. COMP. CODES R. \& REGS. tit. 6, § 750-3.3(a) (proposed Sep. 28, 2011) (expired on February 27, 2013). Setbacks in other states usually are smaller. See, e.g., 58 PA. Cons. STAT. \& 3215(a) (2012) (Pennsylvania requires 200 feet); W.VA. CODE $\S 22-6-21$ (2012) (West Virginia requires 200 feet); N.M. CODE R. $\S 19.15 .17 .10(\mathrm{~A})(3)(\mathrm{d})(2011)$ (repealed effective June 28, 2013) (New Mexico required 500 feet).

265. CoLO. CODE REGS. § 404-1:603(a)(2), :603(a)(1) (2013) (Colorado requires 150 feet or 1.5 times a derrick's height from surface property lines, and 1,000 feet setbacks in high occupancy areas from educational and other group facilities); MD. CODE REGS. 26.19.01.09(G) (2013) (Maryland requires 1000 feet setback from schools or occupied dwellings).

266. COLO. CODE REGS. § 404-1:603, :604 (2013).

267. See, e.g., id. $\S 404-1: 604(\mathrm{c})(2)(\mathrm{G})$ (Colorado requires that "secondary containment devices shall be constructed around crude oil, condensate, and produced water storage tanks"); N.Y. COMP. CODES R. \& REGS. tit 6, § 7503.7(k)(4), (7), (9), (l), (m), (n) (proposed Sept. 28, 2011) (expired Feb. 27, 2013) (as condition of receiving a permit, New York's proposed regulations require an owner to have fluid disposal plan, spill prevention plan, containment system; to use a closed loop tank system for certain drilling fluids and cuttings, and to maintain lined reserve pits in good condition).

268. See, e.g., DeP'T of ENVTl. ConSERVATION, SupPlemental GenERIC ENVTL. IMPACT STATEMENT, 7.1.6, at 7-57 (N.Y. 2011) (New York requirement to report spill within two hours of discovery); N.D. ADMIN. CODE 43-02-03-30 (2012) (North Dakota requirement to notify director within twenty-four hours).

269. See, e.g., N.D. ADMIN. CODE 43-02-03-19.2 (2013) ("All waste associated with exploration or production of oil and gas must be properly disposed of 
to disclose the chemical composition of their fracturing fluid, ${ }^{270}$ and some require energy companies to do baseline testing of water quality before they begin drilling: ${ }^{271}$ we favor both of these information-forcing rules, and discuss them further below. ${ }^{272}$

While local governments do not generally have authority to regulate health and safety issues, they do have the power to regulate land use. A number of localities in various states have sought to prohibit fracturing, ${ }^{273}$ and there has been litigation about whether state law preempts these local ordinances. ${ }^{274}$ The issue has generally been framed in terms of whether the local ordinance is a form of "land use" regulation, or a regulation of the operation of oil and gas wells. ${ }^{275}$ The former is understood to be a permissible local function; the latter is reserved to the state. ${ }^{276}$

in an authorized facility . . . "); 16 TEX. ADMIN. CODE $\S 3.9(1)$ (2012) (Texas rule requiring underground injection control wells); DEP'T OF ENVTL. CONSERVATION, SUPPLEMENTAL GENERIC ENVTL. IMPACT STATEMENT, 7.1.8, at 7-63 (N.Y. 2011) (New York rule requiring approved wastewater treatment plant or recycling).

270. Arkansas, Colorado, Louisiana, Michigan, Montana, Pennsylvania, Texas, and Wyoming all require disclosure. See SUSAN WILLIAMS, IRRC DISCOVERING SHALE GAS: AN INVESTOR GUIDE TO HyDRAULIC FRACTURING 1, 23 (2012), available at http://si2news.files.wordpress.com/2012/03/discoveringshale-gas-an-investor-guide-to-hydraulic-fracturing.pdf. So do West Virginia, Maryland, and Ohio. See W. VA. CODE § 22-6-14 (2012); S.B. 165, 128th Gen. Assemb., 2009-2010 Sess. (Ohio 2010); MD. DeP'T OF THE ENV'T, OIL/GaS WELL COMPLETION REPORT, Form No. MDE/LMA/PER.019, at 3 (2009). New York included a disclosure requirement in its proposed regulations, N.Y. COMP. CODES R. \& REGS. tit 6, § 750-3.7(k)(1), (3) (proposed Sep. 28, 2011) (expired Feb. 27, 2013), and North Dakota is considering such proposals as well, see N.D. ADMIN. CODE 43-02-03-27.1(1)(g) (2013).

271. See, e.g., 58 P.A. Cons. STAT. § 3218(c)(1)(i) (2012) (Pennsylvania's provision authorizing testing and creating rebuttable presumption that a well operator caused contamination within 1000 feet of a well); COLO. CODE REGS. $\$ 404-1: 317 \mathrm{~B}(\mathrm{~d})(4)$ (2013) (Colorado's requirement of baseline surface water data); N.Y. COMP. CODES R. \& REGS. tit 6, $\S 750-3.7(k)(5)$ (proposed Sep. 28, 2011) (New York's proposed, and since expired, requirement of pre-drilling testing).

272. See infra Part VI.A.1.

273. ADAM VANN ET AL., CONG. RESEARCH SERV., HydRAUlic FraCtURING: SELECTED LEGAL ISSUES 1, 27-29 (2013), available at http://www.slideshare .net/MarcellusDN/ r43152.

274. Norse Energy Corp. USA v. Town of Dryden, 964 N.Y.S.2d 714 (N.Y. App. Div. 2013); Robinson Twp. v. Pennsylvania, 52 A.3d 463 (Pa. Commw. Ct. 2012).

275. See, e.g., Norse Energy, 964 N.Y.S.2d. at 714.

276. A similar distinction is found in federal preemption law. See Pac. Gas \& Elec. v. State Energy Res. Conservation Comm'n, 461 U.S. 190, 205 (1983) (holding that the federal government has exclusive authority over the regula- 


\section{Federal Law}

Given the traditional primacy of states in oil and gas regulation, federal law has little to say about fracturing. Indeed, key environmental statutes exempt the practice. ${ }^{277}$ For example, the Safe Drinking Water Act (SDWA) was amended in 2005 to exempt fracturing from regulations that govern injection wells (unless the fracturing fluid includes diesel). ${ }^{278}$ This means SDWA permitting requirements generally do not apply to fracturing, although they do govern the disposal of fracturing waste in injection wells. ${ }^{27}$

The Clean Water Act is generally concerned with pollution of surface water, not groundwater ${ }^{280}$ Even with respect to surface water, the Act contains an exemption for storm water runoff from oil and gas production facilities (which was expanded in 2005), ${ }^{281}$ although energy companies still usually need storm water permits if the runoff is contaminated with waste products or soil sediment. ${ }^{282}$

Oil and gas wastes from exploration and production activity are exempt from Subtitle $\mathrm{C}$ of the Resource Conservation

tion of the safety of nuclear reactors; states are allowed to regulate questions of "need, reliability, [and] cost").

277. For a survey of how federal environmental laws apply to fracturing, see generally VANN ET AL., supra note 273.

278. 42 U.S.C. $\S 300 \mathrm{~h}(\mathrm{~d})(1)(\mathrm{B})(\mathrm{ii})(2012)$ (excluding from the SDWA definition of underground injection "the underground injection of fluids or propping agents (other than diesel fuels) pursuant to hydraulic fracturing operations related to oil, gas, or geothermal production activities"); Energy Policy Act of 2005, Pub. L. No. 109-58, 119 Stat. 594 (2005).

279. Benincasa, supra note 11 at 9 . The exemption does not apply to fracturing fluid containing diesel. See 42 U.S.C. $\$ 300 \mathrm{~h}(\mathrm{~d})(1)$.

280. The Act generally disallows the discharge of any pollutant except in compliance with the Act. See 33 U.S.C. § 1311(a) (2006). Discharge of a pollutant is defined primarily as "any addition of any pollutant to navigable waters from any point source." Id. $\S 1362(12)$. The "navigable waters" are defined in turn as "the waters of the United States, including the territorial seas." Id. $\S 1362(7)$. Although there has been much dispute about the meaning of "navigable waters," see, for example, Rapanos v. United States, 547 U.S. 715, 742 (2006) (concluding in a divided decision that hydrologically connected wetlands are covered); Solid Waste Agencies of N. Cook Cnty. v. U.S. Army Corps of Eng'rs, 531 U.S. 159, 171-72 (2001) (concluding in a divided decision that an isolated gravel pit frequented by migratory birds is not covered), the term is generally assumed not to include groundwater.

281. 33 U.S.C. $\$ 1342(1)(2)$.

282. Id. § 1342(1)(2); see also 33 U.S.C. § 1362(24) (2005 act amending definition of the term "oil and gas exploration, production, processing, or treatment operations or transmission facilities"); Natural Res. Def. Council v. EPA, 526 F.3d 591, 607-08 (9th Cir. 2008) (striking down an EPA effort to broaden permitting exemption for storm water discharge for the oil and gas industry). 
and Recovery Act (RCRA), which regulates the disposal of hazardous waste products. ${ }^{289}$ Natural gas and petroleum are also exempt from the definition of "hazardous waste" under CERCLA; ${ }^{284}$ presumably, therefore, contamination of groundwater by methane is not subject to remedial action under this statute. Many of the chemicals in fracturing fluid are listed as hazardous wastes. A release of such chemicals in large enough volume might conceivably trigger an emergency response action under CERCLA, although small spills or contamination in highly diluted form most likely would not. ${ }^{285}$ The oil and gas industry is also exempt from reporting toxic releases under the Emergency Planning and Community Right-to-Know Act (EPCRTKA). ${ }^{286}$

In contrast, the Clean Air Act applies. As we have seen, EPA issued regulations in April, 2012 governing air emissions from fracturing sites. ${ }^{287}$

\section{CHOOSING A REGULATORY STRATEGY FOR WATER CONTAMINATION}

How, then, should policymakers respond to the water contamination risks of fracturing? The overarching goal, we believe, should be to support the shale revolution by steadily improving our understanding of the water contamination risks and working to reduce those risks. This means the system of regulation must be dynamic. It cannot be designed simply to address known risks using present-day technology. It must be one that stimulates new extraction technologies and new risk control techniques. The best way to achieve this goal, as we will

283. See Solid Waste Disposal Act, 42 U.S.C. § 6921(b)(2)(A) (2006) (creating presumption of no oil-related or gas-related waste under the RCRA); Hannah Wiseman, Regulatory Adaptation in Fractured Appalachia, 21 VILL. ENVTL. L.J. 229, 244-45 (2010) (summarizing regulatory history relating to the determination of whether oil and gas is hazardous waste).

284. 42 U.S.C. $\S 9601(14)$ (F) (2006).

285. See id. $\$ 9601$ (14) (defining hazardous waste to include any waste regulated under the Solid Waste Disposal Act or listed as hazardous under the Clean Water Act and the Clean Act, among other statutes); id. §9602 (establishing reportable quantities of hazardous wastes). Permanent removal actions under CERCLA require that the site be listed on the National Priorities List, which would be difficult to achieve for localized spills in relatively small quantities. See id. $\S 9605(\mathrm{e})$.

286. 42 U.S.C. $\S 11023(\mathrm{~b})(1)(\mathrm{A})(2006)$.

287. See 40 C.F.R. $\$ \S 63.40-63.44$ (2012); John M. Broder, U.S. Caps Emissions in Drilling for Fuel, N.Y. TiMES, Apr. 18, 2012, http://www.nytimes.com/ 2012/04/19/science/earth/epa-caps-emissions-at-gas-and-oil-wells.html?_r=0. 
explain, is by adopting a blended regulatory scheme that combines best practices regulation with liability for fracturingrelated harms.

We start in Section A with observations about the dangers of regulatory overkill. The miscellaneous risks we have labeled "familiar," canvassed in Part III, are unlikely to mobilize widespread public opposition to fracturing. The danger of water contamination is different, so it is all the more critical to calibrate regulatory responses correctly.

Section B surveys five alternative regulatory strategies: (1) prohibitions; (2) command and control regulations; (3) information disclosure; (4) liability rules; and (5) Coasean bargains. ${ }^{288}$

Section $C$ highlights four factors that should influence the choice of regulatory strategy by drawing on the literature on ex ante versus ex post regulation, and the tradeoff it highlights about the timing of when to determine optimal behavior: (1) whether a uniform solution is likely to be optimal; (2) the magnitude of the expected harm; (3) the settlement costs of making case-by-case determinations ex-post; and (4) the novelty of the relevant technology. While the first two are familiar, the third and fourth have not featured as prominently in the literature.

Section D applies these factors to fracturing, recommending a blended strategy of best practices regulations and liability. For issues that are already well understood, we would rely on command and control regulations to enforce best practices. For issues that are unique to fracturing and are not yet well understood, we would rely on liability rules, motivating the industry to take precautions and develop risk-reducing innovations. We also would ban fracturing in a limited number of sensitive areas and would require certain types of disclosure.

Finally, Section E sets forth in summary form our proposed regulatory strategy.

\section{A. THE DANGER OF REgUlatory OVERKILL}

\section{Public Anxiety and Love Canal}

The prospect of groundwater contamination can elicit a response known as "dread." ${ }^{289}$ In part this is because water is a

288. Compare infra Part V.B. with the discussion of the "regulatory toolkit" in JAMES SALzMAN \& BARTON H. THOMPSON, JR., ENVIRONMENTAL LAW AND PoliCY 44-51 (2d ed. 2007).

289. See Paul Slovic, Perception of Risk, 236 SCIENCE 280, 283 (1987) (de- 
necessity of life. If land is deprived of a source of water, its value can be seriously impaired. If the contamination is not detected, livestock and crops may be destroyed. Human consumption may lead to illness. We are also uneasy because we know comparatively little about groundwater. Typically, we do not know where it comes from, where it goes, whether aquifers are interconnected, and how long it would take for contamination to work its way out of the system. Thus, the prospect of water contamination is uniquely disturbing because we do not fully understand how to prevent or cure it.

We know that the prospect of groundwater contamination can motivate the public to support draconian regulatory measures. In the late $1970 \mathrm{~s}$, extensive publicity about toxic chemicals leaking into basements in Love Canal (near Niagara Falls, New York) produced a groundswell of concern about hazardous wastes contaminating ground water. ${ }^{290}$ Congress responded by enacting CERCLA, which generated massive funding for excavating and incinerating soil at hazardous waste disposal sites. ${ }^{291}$ Federal laws on disposal of hazardous wastes were also beefed up, and a de facto moratorium was imposed on new solid waste disposal sites near urban areas. ${ }^{292}$ There is no question that regulation of toxic waste had previously been too lax. Yet with the benefit of hindsight, many commentators believe the cost of the response was disproportionate to the benefit. ${ }^{293}$ The pressure driving this reaction was public apprehen-

fining "dread risk" as one characterized by a perceived lack of control, catastrophic potential, and an inequitable distribution of risks and benefits).

290. Timur Kuran \& Cass R. Sunstein, Availability Cascades and Risk Regulation, 51 STAN. L. REV. 683, 691-92 (1999).

291. Id. at 691-98; see also supra notes 280-88 and accompanying text (discussing oil and natural gas exception to CERCLA).

292. See, e.g., Benincasa, supra note 11, at 8-9.

293. See, e.g., James T. Hamilton \& W. Kip Viscusi, The Magnitude and Policy Implications of Health Risks from Hazardous Waste Sites, in ANALYZING SUPERFUND: ECONOMICS, SCIENCE AND LAW, 55, 78-81 (Richard L. Revesz \& Richard B. Stewart eds., 1995); Katherine D. Walker et al., Confronting Superfund Mythology: The Case of Risk Assessment and Management, in ANALYZING SUPERFUND: ECONOMICS, SCIENCE AND LAW, at 25, 47-50; NAT'L RESEARCH COUNCIL, ENVIRONMENTAL EPIDEMIOLOGY, VOL. 1: PUBLIC HEALTH AND HAZARDOUS WASTE 256-57 (1991). Although debate persists about the social benefits of remediating waste sites, many commentators agree that the transaction costs generated by the draconian liability scheme were disproportionate to any benefits obtained. See, e.g., Michael B. Gerrard, Demons and Angels in Hazardous Waste Regulation: Are Justice, Efficiency, and Democracy Reconcilable?, 92 NW. U. L. REV. 706, 717 (1998). 
sion about groundwater, ${ }^{294}$ stoked by the media and advocacy organizations. ${ }^{295}$ It would be unfortunate if a similar dynamic were to stifle the shale revolution. The solution, we believe, is to adopt a sensible regulatory regime that reassures the public, motivates industry to take appropriate precautions, and provides incentives to develop risk-reducing innovations over time.

\section{Precautionary Principle}

A related point concerns the relevance of the "precautionary principle." Translated roughly as "better safe than sorry,"296 this principle is often invoked to restrict the use of new technology until potential risks are better understood. ${ }^{297}$ The precautionary principle is widely invoked in Europe and has gained a foothold in the United States, although it has also generated significant pushback among regulatory theorists here ${ }^{298}$ For several reasons, we think it is unhelpful in analyzing water contamination risks of fracturing.

First, the precautionary principle is most commonly invoked for potentially catastrophic risks, ${ }^{299}$ such as nuclear power, genetically modified organisms, human cloning, and climate change. In each case, the harm is potentially irreversible and could affect large numbers of people. In contrast, fracturing poses risks primarily to individual aquifers. ${ }^{300}$ It is true, of course, that fracturing could destroy an aquifer's usefulness for human consumption or agriculture, and that as fracturing be-

294. See GREGG EASTERBROOK, A MOMENT ON THE EARTH 638-39 (1995).

295. Id. at 606-07, 638-39 (1995); Molly J. Walker Wilson \& Megan P. Fuchs, Publicity, Pressure, and Environmental Legislation: The Untold Story of Availability Campaigns, 30 CARDOZO L. REV. 2147, 2193-2200 (2009). For a case study highlighting the role of anxiety about water contamination in generating opposition to landfills, see Thomas W. Merrill, The Story of SWANCC: Federalism and the.Politics of Locally Unwanted Land Uses, in ENVIRONMENTAL LAW STORIES 283, 290-91 (Richard J. Lazarus \& Oliver A. Houck eds., 2005).

296. Frank B. Cross, Paradoxical Perils of the Precautionary Principle, 53 WASH. \& LEE L. REV. 851, 851 (1996).

297. See generally EUROPEAN RISK ForUm, THE PRECAUTIONARY PRINCIPLE: APPLICATION AND WAY FORWARD 18-20 (2011) (defining and discussing the precautionary principle's origins).

298. See, e.g., CASs R. Sunstein, LAws of Fear: Beyond the PrecauTIONARY PRINCIPLE (2005) (discussing various mechanisms that enable a fearful public to invoke the precautionary principle, which yields unjustified intrusions upon civil liberties).

299. See Frederick Schauer, Is it Better to Be Safe than Sorry?: Free Speech and the Precautionary Principle, 36 PEPP. L. REV. 301, 304-06 (2009).

300 . Spence, supra note 256 , at 492-93. 
comes more widespread, more aquifers are put at risk. But substitute sources of water would remain available at a cost. In the extreme case, contaminated water could be pumped out and decontaminated. ${ }^{301}$ So the potential harm, although not trivial, is localized and reversible.

Second, critics of the precautionary principle urge us to consider the risks not only of adopting a new technology but also of not adopting it. ${ }^{302}$ Although fracturing poses environmental risks, a general ban on the practice would also entail enormous costs, including higher energy prices, reduced economic activity and employment, deteriorating balance of payments, not to mention the risks associated with continued dependence on foreign sources of energy, greater emissions of greenhouse gases and, of course, reliance on other risky sources of energy (e.g. coal, nuclear power, offshore drilling). Indeed, a ban on fracturing would arguably exacerbate global warming, a risk that itself is often cited as subject to the precautionary principle. All of which supports the conclusion that the proper regulatory response to fracturing is to weigh all expected risks and benefits, not merely a select list of environmental risks.

Third, invocation of the precautionary principle ignores the decades of experience we already have with fracturing. Although fracturing in shale is only about a decade old, fracturing itself has been used in oil and gas production in the United States since the $1940 \mathrm{~s} .{ }^{303}$ Since then, the industry has executed over two million "frack jobs" in the U.S. It is also widely used around the world. This experience should inform preliminary judgments about the risks of fracturing in shale. The evidence suggests that the risk of widespread or systemic devastation to water supplies is remote, ${ }^{304}$ and the prospect of local contamination is manageable as long as fracturing is done properly. ${ }^{305}$

In an effort to develop a more rigorous foundation for what an optimal regulatory regime might look like, we turn to a consideration of different regulatory strategies, and how to choose

301. See Ground Water Cleanup at Superfund Sites, EPA (Dec. 1996), http://www.epa.gov/superfund/health/conmedia/gwdocs/brochure.htm (explaining that ground water can be treated by pumping it to the surface, decontaminating it, and then discharging it back into the ground or into a stream or river).

302. E.g., Cross, supra note 296 , at 860 .

303. Benincasa, supra note 11 , at 8 .

304. Spence, supra note 256, at 492-93.

305. See Daniel Gilbert \& Russell Gold, As Big Drillers Move in, Safety Goes Up, WALL ST. J., Apr. 2, 2013, at A10. 
among them.

\section{B. Five Possible Regulatory Strategies}

\section{Prohibitions}

One strategy for dealing with an environmental risk is simply to ban it. This strategy has a long lineage, from local ordinances banning gunpowder in central cities (because of the danger of fire $)^{306}$ to European laws banning genetically modified foodstuffs. ${ }^{307}$ Likewise, local zoning codes keep certain activities, such as industrial plants, out of sensitive areas like residential neighborhoods. Prohibitions can be temporary (moratoria) or permanent, and they can be jurisdiction-wide or local.

Activities should be banned when the risks of allowing them outweigh the benefits. A ban is more likely if good substitutes are available; for instance, gunpowder can be stored outside central cities. Prohibition is obviously the most protective regulatory strategy. If an activity is prohibited, the associated risk is zero. A downside of prohibition, of course, is that it deprives society of the social benefits of the activity. When the benefits are substantial and the risks are manageable, prohibition represents regulatory overkill. Prohibition also impedes innovation by limiting possibilities for experimentation in developing new ways to reduce the risk.

\section{Command and Control Regulation}

An alternative to banning an activity is regulating it. The oldest and most common form of command and control regulation mandates "best practices" to minimize external harms, such as rules requiring ships to carry lifeboats, cars to have seat belts, and the like. This type of regulation typically requires all firms to adopt practices that reflect the "state of the art," meaning something more stringent than common practice that is still technologically and economically feasible. ${ }^{308}$ The implicit judgment is that if some firms can operate profitably while providing certain harm-preventing measures, all firms

306. See William J. NovaK, THE People's Welfare: LAW and REgUlaTION IN NINETEENTH-CENTURY AMERICA 60-71 (1996) (discussing the relationship between restricting gunpowder storage and regulation).

307. EUROPEAN RISK FORUM, supra note 297, at 23-24.

308. RESTATEMENT (THIRD) OF TORTS: PRODUCTS LIABILITY $\S 2$, cmt. d. See, e.g., The T.J. Hooper, 60 F.2d 737 (2d Cir. 1932) (holding that it was negligent for coastal tug to operate without a radio receiver given that some tug boat operators in the industry provided radio receivers for their vessels). 
should be required to do so. ${ }^{309}$

Although command and control regulation is less protective than prohibition, it can still offer significant reassurance to the public. It is probably more reassuring than pollution taxes or the prospect of ex post litigation to recover damages for harms, since the latter have uncertain effects and are more difficult to perceive as providing an assurance of "safety."

The familiar downside of command and control regulation is that it can yield inefficient regulations, since they are usually defined by the state of existing technology instead of a rigorous assessment of costs and benefits. Thus, command and control regulation can result in over-regulation of activity, which yields a deadweight loss, or in under-regulation, which yields excessive risk. ${ }^{311}$ As with prohibitions, such regulations can also discourage innovation by freezing best practices at a moment in time.

Notwithstanding these defects, regulated industry often prefers command and control regulation over other forms of regulation because it generates relatively predictable regulatory costs. Especially in making significant long term investments, firms may prefer certain-even if potentially excessive-costs to highly uncertain costs. ${ }^{312}$

309. More sophisticated command and control regulations are expressed as abstract standards, such as the maximum allowable release of harmful substances. For water pollution, these are called "effluent standards." 33 U.S.C. $\S 1314$ (b) (2006). They usually use verbal formulas such as "best available," "best achievable," or "best practicable," and are set by determining how much various technologies can reduce effluents. Id.; see also Notice of Final 2010 Effluent Guidelines Program Plan, 76 Fed. Reg. 66,286 (Oct. 26, 2011). Effluent standards, like best practices regulations, are generally set using existing technology as the relevant benchmark. Once the relevant range of standards is identified based on existing technology, however, it is possible to use costbenefit analysis in selecting among appropriate technological benchmarks. See, e.g., Entergy Corp. v. Riverkeeper, Inc., 556 U.S. 208, 226 (2009) (upholding the use of cost-benefit analysis in setting effluent limits for thermal pollution from power plants).

310. See, e.g., Howard Latin, Ideal Versus Real Regulatory Efficiency: Implementation of Uniform Standards and "Fine-Tuning" Regulatory Reforms, 37 STAN. L. REV. 1267, 1271 (1985).

311. See, e.g., Bruce A. Ackerman \& Richard B. Stewart, Reforming Environmental Law, 37 STAN. L. REV. 1333, 1335-37 (1985).

312. Cf. Khalid A. Rahim, Why Pollution Standards Are Preferred by Industries: Pragmatism and Rent-Seeking Behavior, 16 ENVIRONMENTALIST 49, $52-53$ (1996) (noting that industry would also have more certainty of political influence, indirectly providing more predictable costs). 


\section{Disclosure}

A third strategy requires the party primarily responsible for the external risk to disclose information about it. This is a prominent strategy in environmental law, ${ }^{313}$ and is also one of the duties imposed by tort law, such as informed consent in medical malpractice and the duty to warn in products liability law.

Information disclosure has regulative effects. When forced to disclose risks, firms often make changes to eliminate or reduce them, if only to avoid adverse publicity or having consumers vote with their feet. ${ }^{314}$ Yet information disclosure is a more tentative regulatory response than prohibition or command and control. It assumes that different persons respond to risks differently, that we should rely in part on potential victims to avoid risks, and that disclosure can stimulate innovation. ${ }^{315}$ The most general assumption is that more and better information about risks is a good thing, which is hard to dispute. One must remember, however, that gathering and disseminating information can be costly, and that information overload can be counterproductive.

313. It is reflected in environmental impact statements required by the $\mathrm{Na}$ tional Environmental Policy Act (NEPA), 42 U.S.C. $\$ 4332$ (c)-(d) (2006), and its state analogues, the Toxic Release Inventory required by the Emergency Planning and Community Right-to-Know Act, 42 U.S.C. $\S 11023$ (a) (2006), OSHA's Hazard Communications Regulation, 29 C.F.R. $\$ 1910.1200$ (2012), and California's Proposition 65, CAL. HeALTH \& SAFETY CODE $§ 25249.6$ (2013).

314. See Paul R. Kleindorfer \& Eric W. Orts, Informational Regulation of Environmental Risks, 18 RISK ANALYSIS 155, 165 (1998) ("[Information disclosurel relies heavily on markets and public opinion . . . enforcement of standards is expected to occur through the combined pressure of economic markets and public opinion."); see also Shameek Konar \& Mark A. Cohen, Information as Regulation: The Effect of Community Right to Know Laws on Toxic Emissions, 32 J. ENVTL. ECON. \& MGMT. 109, 118 (1997) (describing the effects of Toxic Release Inventory disclosure requirements on firm performance, finding that those firms with lower TRI emissions outperformed those classified as heavy polluters, and that TRI disclosure generally had negative impacts on a firm's share price).

315. See generally WESLEY A. MAGAT \& W. KIP VISCUSI, INFORMATIONAL APPROACHES TO REGULATION (1992) (examining how people respond to disclosed safety risks); W. KIP VISCUSI, RISK BY CHOICE (1983) (examining the manner in which government regulation intersects with market forces and individual choice in regard to risks).

316. See generally, e.g., Troy A. Paredes, Blinded by the Light: Information Overload and Its Consequences for Securities Regulation, 81 WASH. U. L. REV. 417 (2003). 


\section{Liability Rules}

A fourth regulatory strategy operates retrospectively rather than prospectively, levying monetary sanctions on firms that have imposed external harms on others. Common law tort liability is the most familiar example. Whether the harm is a collision, a spill, or the invasion of property by harmful substances, injured persons can sue and recover damages if the perpetrator has breached the relevant duty of care. Other types of liability rules include pollution taxes, deposit and refund schemes, and cap and trade regulations. ${ }^{317}$ Similarly, CERCLA, the federal "Superfund" statute, uses liability to allocate the cost of cleaning up hazardous waste sites. ${ }^{318}$ In each case, liability rules operate after the fact to levy a financial charge on externality-generating activity.

Liability rules have two significant advantages. The first is deterrence. To avoid liability, actors have an incentive to reduce (or "internalize") harms they are likely to cause, especially if liability is imposed on the party with the best information and expertise to minimize risks efficiently. Second, liability provides compensation to those who suffer injury. The common law of torts and the Oil Pollution Act, ${ }^{319}$ among other statutes, have this compensatory feature, although other liability rules, such as pollution taxes, cap and trade schemes, and CERCLA, do not.

In practice, liability rules may not fully deliver on these advantages. They often are accompanied by uncertainty because they operate after harm has occurred. In the common law of torts, for instance, we sometimes do not know until the jury returns whether particular actors will be liable. For this reason, it can be difficult for firms to predict the costs of their actions, leading to over- or under-deterrence. For the same rea-

317. Whether pollution taxes and cap and trade schemes are properly regarded as liability rules is debatable. Other commentators have classified these sorts of regulatory tools as a form of command and control regulation. See Kyle D. Logue, Coordinating Sanctions in Tort, 31 CARDOzo L. REV. 2313, 2325 (2010). Pollution taxes and cap and trade schemes are similar to liability rules in that they set a price on an externality which is imposed only after it is generated. It is also true, however, that greater ex ante regulatory effort goes into setting up a pollution tax or cap and trade scheme than is the case under other liability rules like the common law of tort. For present purposes, nothing turns on this taxonomic issue, since we do not consider pollution taxes or cap and trade to be feasible options for dealing with water pollution risks caused by fracturing.

318. 42 U.S.C. $\S 9607$ (2006).

319. 33 U.S.C. $\$ 2702(2006)$. 
son, the compensatory feature of liability is also uncertain; it is not necessarily reassuring to know we can file a law suit if a new risk threatens us with injury. ${ }^{320}$

Notwithstanding these imperfections, the prospect of liability clearly has a powerful effect on businesses. For instance, products liability law has transformed the way consumer products are designed, and CERCLA has had a similar effect on waste disposal. ${ }^{321}$ Liability, therefore, is especially effective in encouraging risk-reducing innovation. This is a powerful argument for liability rules, even with all their uncertainties and imperfections.

\section{Coasean Bargains}

A final strategy, associated with the work of Ronald Coase, is to regulate external harms by contract. ${ }^{322}$ Contractual solutions are unrealistic when transaction costs are high, as with highway accidents and smog. ${ }^{323}$ Yet contractual solutions may sometimes prove feasible for water contamination from fracturing. Before energy companies begin drilling, they enter into mineral leases with owners of the mineral rights, typically the surface owners of the land above the oil or gas deposit. This lease can address water contamination. For example, landowners in Noble County, Ohio, recently negotiated lease provisions requiring the energy company to test water quality before and after drilling and barring the company from drawing water for fracturing from the leaseholders' land. ${ }^{324}$ One could imagine lease provisions that go even further, either making landown-

320. See generally STEPHEN D. SUGARMAN, DoIng AWAY WITH PERSONAL INJURY LAW 35-40 (1989) (discussing the deficiencies of tort as a compensation system).

321. There is disagreement about whether the social benefits associated with these forms of liability exceed the social costs. See A. Mitchell Polinsky \& Steven Shavell, The Uneasy Case for Product Liability, 123 HARV. L. REV. 1437 (2010) (examining products liability); sources cited supra note 284 (CERCLA). But there is little doubt that the prospect of products liability and CERCLA liability have changed the behavior of business firms. See, e.g., Carol E. Dinkins, George O. Wilkinson, Margaret E. Peloso \& Thomas S. Meriwether, The Role of Public and Private Litigants in Promoting Environmental Corporate Responsibility, 21 FORDHAM ENVTL. L. REV. 123, 130-32, 135 (2010); Mark Geistfeld, Products Liability, in 1 ENCYCLODEDIA OF LAW AND ECONOMICS, SECOND EDITION, TORT LAW AND ECONOMICS 287, 300-04 (Michael Faure ed., 2009).

322. R. H. Coase, The Problem of Social Cost, 3 J.L. \& ECoN. 1 (1960).

323. See id. at 16-19.

324. Keith Schneider, New Value for Land in Rural Ohio, N.Y. TTMES, June 5,2012 , at A11. 
ers whole for any water contamination or releasing energy companies from any water contamination claim. In either case, the price would be adjusted for the enhanced or diminished rights. ${ }^{325}$ Regulators could enhance the prospects for such solutions by prescribing model contracts, which would serve as defaults the parties would be free to modify.

Other Coasean solutions are also imaginable. For example, the driller could purchase both mineral rights and groundwater rights, and could agree to sell groundwater to the landowner at a specified price and quality. Or energy companies could purchase the full column of rights (a fee simple), effectively uniting the mineral rights, groundwater rights, and surface rights under single ownership, with the objective of maximizing the joint value of the rights considered separately.

Coasean bargains nevertheless have significant limitations in this context. If fracturing threatens harm to parties not participating in a lease (like neighboring landowners), contractual solutions become more difficult, if only because of the large number of potentially affected persons. Another problem more specific to the oil and gas industry is the prevalence of split estates, in which the surface owner transfers subsurface mineral rights to a third party at $t_{1}$, and the owner of the mineral estate later enters into a lease with an energy company allowing fracturing at $t_{2}{ }^{326}$ In these circumstances, the surface owner may have bargained away all rights to receive royalties from oil and gas development at $t_{1}$, and thus will view the costs of fracturing at $t_{2}$ in purely negative terms. Indeed, the surface owner may resent the mineral rights owner's good fortune in benefitting from the unanticipated emergence of fracturing, and may seek to obstruct fracturing as a way to force a renegotiation of the decision to split the estate. This sort of "holdup" is not an auspicious setting for Coasean bargaining.

\section{FOUR FACTORS INFLUENCING THE CHOICE OF REGULATORY STRATEGY}

This brief survey suggests that regulatory strategies present a series of tradeoffs, for instance, in protecting against

325. Groundwater contamination may, in some cases, trigger general liability policies of a polluter. See, e.g., Norfolk S. Corp. v. Cal. Union Ins. Co., 859 So. 2d 167, 190 (La. Ct. App. 2003).

326. See generally Timothy Fitzgerald, Evaluating Split Estates in Oil and Gas Leasing, 86 LAND ECON. 294 (2010) (providing background information on split estates and discussing their decreased value to oil and gas developers). 
risk, foreclosing benefits from risky activities, reassuring the public, operating efficiently, and encouraging innovation. These tradeoffs should inform our choices about regulatory strategies for water contamination from fracturing. It is worth asking, however, whether there is any more systematic basis for choosing among regulatory strategies. If our goals are to encourage socially valuable behavior while also assuring an optimal level of safety at a minimal level of administrative cost, which of these five strategies-or what combination of them-should we choose? How do we strike the balance?

While there is surprisingly little general theory on this question, ${ }^{327}$ a useful starting point is the literature on ex ante versus ex post regulation. While ex ante regulation seeks to reduce harmful externalities before they occur, ex post regulation puts a price or sanction on harmful events after they occur, thereby creating an incentive to reduce their incidence. ${ }^{328}$ The focus of this literature is whether it is cheaper to determine optimal behavior before or after some discrete accident or other external harm has taken place ${ }^{329}$ Of course, with any system of regulation, there will be at least some regulatory activity both before and after the decision about optimal behavior is made. Under a system that determines optimal behavior ex ante, resources must be devoted to enforcing the designated rules of conduct. Likewise, even under a system that determines optimal behavior ex post, resources must be devoted to establishing such a system and articulating general guidelines before par-

327. See generally REgULATION VERSUS LITIGATION: PERSPECTIVES FROM ECONOMICS AND LAW (Daniel P. Kessler ed., 2011) (essays by Richard Posner, Fred Schauer, and Richard Zeckhauser); Steven Shavell, Liability for Harm Versus Regulation of Safety, 13 J. LEGAL STUD. 357 (1984).

328. See Robert Innes, Enforcement Costs, Optimal Sanctions, and the Choice Between Ex-Post Liability and Ex-Ante Regulation, 24 INT. REV L. \& ECON. 29, 35-38 (2004); Samuel Issacharoff, Regulating after the Fact, 56 DEPAUL L. REv. 375, 379-80 (2007); Donald Wittman, Prior Regulation Versus Post Liability: The Choice Between Input and Output Monitoring, 6 J. LEGAL STUD. 193, 199-200 (1977). Louis Kaplow, in an important article, assimilates the distinction between ex ante and ex post regulation to the distinction between rules and standards. Louis Kaplow, Rules Versus Standards: An Eco. nomic Analysis, 42 DUKE L.J. 557, 559-62 (1992). Although we agree that there is a strong association between ex ante regulation and the use of rules, and that standards generally entail ex post regulation, we do not foreclose the possibility that ex post regulation can have significant rule-like elements. A pollution tax precisely calibrated to the tonnage of pollutants emitted would be an example.

329. Kaplow, supra note 328, at 572 ("The difference in promulgation costs favors standards, whereas that in enforcement costs favors rules."). 
ticular harms are investigated. The basic principle for choosing between ex ante and ex post regulation, then, is to pick the regulatory approach that minimizes the sum of external costs and regulatory costs. With ex ante regulation, the regulatory costs are front loaded; with ex post regulation, they are back loaded.

Consider a choice between requiring manufacturers to install safety devices like airbags in cars, and examining particular vehicles after accidents to determine whether they were designed safely. The first system (e.g., command and control regulation) will entail extensive investigations of airbags and a complicated process to shape the parameters of the regulation. Once the rule is promulgated, it must be enforced with occasional spot checks, recall orders, and the like. Even so, more costs will be consumed in crafting the regulation than in enforcing it. ${ }^{330}$ In contrast, under a system that examines cars after accidents (e.g., a liability rule), relatively little is needed to get the system up and running, and regulatory costs shift to the enforcement phase when accidents are investigated.

This framework only pushes us to the next question: what factors determine the relative effectiveness of ex ante or ex post regulation, and in particular, whether fewer social resourcesincluding accident costs, costs of preventing accidents, and administrative costs-will be consumed by regulating in one mode or the other? The existing literature here is less helpful. Distilling from a variety of commentary, we suggest four factors.

\section{Heterogeneity of Risk}

First, how much variation is there among the actions producing the relevant harm? ${ }^{331}$ Injuries from secondary collisions, for instance, are likely to be similar even in different types of cars. This relative uniformity favors ex ante regulation (e.g. mandatory installation of passive restraints). Conversely, every accident in which human behavior plays a significant role is different, involving heterogeneous variables such as how the drivers were driving, whether they were impaired, the road and weather conditions, and so forth. Here it seems more appropriate to apply a general standard of reasonable care and make judgments ex post, so we do not have to provide rules in ad-

330. Jerry L. Mashaw \& David L. Harfst, The Struggle for Auto SAFETY 221-22, 228-29 (1990) (detailing the extensive costs and obstacles to implementing passive restraint rules for automobiles).

331. Kaplow, supra note 328, at 563-64. Kaplow briefly mentions this factor but offers little discussion of it. 
vance for an almost infinite range of scenarios.

\section{Magnitude of Expected Harm}

A second factor in choosing between ex ante and ex post regulation is the expected frequency and severity of the harm. A large expected harm is more likely to justify the upfront expenditure of resources needed for ex ante rules. ${ }^{332}$ Thus, if many people are killed and injured in car crashes each year, this justifies rules requiring seat belts. ${ }^{333}$ Even if the probability of harm is low, if the severity of the harm is great enough, the magnitude of expected harm may justify ex ante regulation, as in the case of meltdowns in nuclear plants. Conversely, if a harm is uncommon and not especially severe, it probably is more cost effective to rely a general standard of care applied after the fact. Consider the risk of being struck by a ball hit out of a sports stadium. ${ }^{344}$ These accidents are rare and, unless someone is struck in the head, injuries are not severe. Therefore, it is cheaper to wait for relatively rare accidents and then determine responsibility after the fact.

\section{3. "Settlement" Costs of Ex Post Judgments}

A third factor influencing the choice of regulatory approach, which has received little attention in the literature, is the cost of making case-by-case judgments ex post. Borrowing from the takings literature, we call this variable the "settlement costs" of engaging in ex post enforcement of a standard. ${ }^{335}$

332. Kaplow argues that the frequency with which the two types of costs (promulgation costs and enforcement costs) will be incurred is the primary factor in choosing between rules and standards. Kaplow, supra note 328, at 573; see also Noam Sher, New Differences Between Negligence and Strict Liability and Their Implications on Medical Malpractice, 16 S. CAL. INTERDISC. L.J. $335,344-45$ (2007) (discussing relative advantages of liability regimes based on enforcement costs).

333. The National Highway Traffic Safety Administration has required by rule that all new vehicles have seat belts since 1968. The NHTSA adopted this rule in Federal Motor Vehicle Safety Standard 208; the current form of this regulation is in 49 C.F.R. $\$ 571.208$ (2012). All states except New Hampshire now require by law that people wear seat belts while driving.

334. Bolton v. Stone, [1951] A.C. 850 (H.L.) 852-54 (appeal taken from Eng.).

335. See Frank I. Michelman, Property, Utility, and Fairness: Comments on the Ethical Foundations of "Just Compensation" Law, 80 HARV. L. REV. 1165, 1214 (1967). Michelman's discussion is recast in terms of deterrence and compensation in Michael A. Heller \& James E. Krier, Deterrence and Distribution in the Law of Takings, 112 HARV. L. Rev. 997, 1004 (1999). See also ROBERT COOTER \& THOMAS ULEN, LAW \& ECONOMICS 324 (5th ed. 2007) (discussing 
Settlement costs can vary substantially in different contexts. If the sources of an external harm are diffuse, or victims are numerous, the costs of case-by-case adjudication may be prohibitive. Consider the case of urban smog. It would be impractical to impose liability on individual drivers, because there are so many sources of smog and everyone is harmed, at least to an extent. When settlement costs are high, ex ante rules (e.g., requiring all cars to have catalytic converters) may be the only feasible regulation. ${ }^{336}$

\section{Novelty of Risk}

A fourth factor, which is not extensively addressed in the literature, is the novelty of the risk. When technology is new, we can predict some harm that it could cause, but not all of them, and not always with confidence about their magnitude and severity. Also, it is especially difficult to devise solutions for these harms. Effective predictions and solutions-and, thus, effective ex ante regulation-require experience. Without experience, we generally will be better off with some form of ex post regulation.

For example, when vehicles powered by internal combustion engines were first invented, it may have been possible to predict that they would cause accidents and frighten horses. But it took time and ingenuity to develop solutions (e.g., better brakes and mufflers). Meanwhile, no one predicted that engines would cause urban smog. It took experience to design (and mobilize popular support for) regulations addressing this unexpected problem. Similar stories can be told about steam boilers, organ transplants, and other novel technologies. The general lesson is that we need significant exposure to a novel technology before developing efficient ex ante regulations.

To sum up, then, we have, in a very rudimentary form, a general framework for choosing between ex ante and ex post regulation. The theory consists of a general principle: minimize the sum of ex ante and ex post costs of creating incentives for optimal behavior. The general principle is fleshed out with four factors illuminating sources of these costs: whether the sources of the harm are heterogeneous; whether the expected harm is

the problems of settlement costs when individual harms are small and injurers are numerous).

336. James E. Krier \& Edmund URsin, Pollution and Policy: A Case ESSAY ON CALIFORNIA AND FEDERAL EXPERIENCE WITH MOTOR AIR POLLU. TION, 1940-1975, at 158 (1977). 
high; whether settlement costs of allocating responsibility ex post are high; and whether the technology is novel.

\section{D . APPLYING THESE FACTORS TO THE RISK OF WATER POLLUTION FROM FRACTURING}

This Section applies this framework to the risks of water pollution from fracturing and recommends a blended regulatory strategy, using command and control regulation for issues that are already well understood with liability as a backstop for these and other issues.

\section{Heterogeneity of Risk}

In controlling water pollution from fracturing, some sources of the risk are homogeneous while others are heterogeneous. Virtually all oil and gas production poses the risk of blowouts, ${ }^{337}$ leaks from vertical drill pipes into aquifers, and improper disposal of drilling waste and produced water. ${ }^{338}$ Each of these risks is present in conventional drilling (i.e., vertical drilling in porous rock) as well as fracturing, and technologies are available to address them. For example, blowout preventers are by now familiar, and the need for them is sufficiently uniform to require them. ${ }^{339}$ The same is true of rules governing the thickness and depth of well casings (to prevent leaks), as well as surface containment ponds for drilling waste and the safe transportation of produced water. ${ }^{340}$ Other water contamination

337. Blowouts are "gushers" or the uncontrolled release of gas or oil. See MARK ZOBACK ET AL., WORLDWATCH INST., ADDRESSING THE ENVIRONMENTAL RISKS FROM SHALE GAS DEVELOPMENT 8-9 (2010); see also Seamus McGraw, Pennsylvania Fracking Accident: What Went Wrong, POPULAR MECHANICS (Apr. 21, 2011, 1:00 PM), http://www.popularmechanics.com/science/energy/ coal-oil-gas/pennsylvania-fracking-accident-what-went-wrong-5598621 (detailing a widely-reported near-blowout at a Pennsylvania fracking operation run by Chesapeake Energy).

338. Produced water is briny water from deep below the earth's surface that comes up with the oil or gas during the drilling process. See supra Part IV.A.1.

339. States are already discussing and implementing such requirements. For example, Colorado Oil and Gas rules incorporate a blowout preventer requirement, and one was recently proposed by the Texas Railroad Commission (the state body that oversees oil and gas exploration) as part of broad changes to the state's regulation of energy extraction. 2 COLO. CODE REGS. $\$ 404$ 1:603(e)(4) (2013) ("Blowout Prevention Equipment"); Kate Galbraith, Proposed Rules on Fracking Gain Cautious Praise, N.Y. TIMES, Dec. 9, 2012, at A39 (describing proposed Texas rules including blowout prevention equipment).

340. See, e.g., FIRST 2011 DOE REPORT, supra note 10, at 28 (noting the 
risks are unique to fracturing, but also present issues that should not vary greatly from one fracturing site to another, including the risk of surface spills of fracturing fluid and of the improper disposal of flow-back. ${ }^{341}$ Best practices regulations are also appropriate for this sort of issue-indeed, they already are common in states with oil and gas drilling. ${ }^{342}$

We assume that best practices regulations would be adopted by the relevant regulatory authority through notice and comment rulemaking. They would be developed through a variety of sources. The oil and gas industry would have an interest in proposing such regulations, if only to assure that maverick operators would not create spills or leaks that would exacerbate public uneasiness about fracturing. Other sources of proposed regulations would include manufacturers of control equipment, environmental organizations, and associations of local landowners. Regulations adopted by other jurisdictions could act as a source of inspiration, with trade associations, environmental groups, and perhaps the federal government serving as clearinghouses to disseminate the relevant information from one jurisdiction to another. ${ }^{343}$

While some risks are homogeneous-and thus are especially well suited to this sort of effort-others are clearly heterogeneous, ${ }^{344}$ including the risk of fracturing fluid or methane escaping from target shale beds and migrating to aquifers, and the risk of vibrations from fracturing dislodging methane deposits near the surface or substances at the bottom of water

need for well casing to be thick, muti-layered, and properly set, and describing well casing as an "ideal example" of a best practices approach); id. at 20 (recommending spill-containment technologies).

341. Flow-back is used fracturing fluid that is pushed back to the surface by the pressure of gas and oil released in the fracturing process. See supra Part IV.A.1.

342. See supra Part IV.A.2 (describing and citing various state regulations).

343. Hannah J. Wiseman, Remedying Regulatory Diseconomies of Scale, 94 B.U. L. REV. (forthcoming Jan. 2014) (manuscript at 51, 61-62), available at http://papers.ssrn.com/sol3/papers.cfm?abstract_id=2257047.

344. See George E. King, Thirty Years of Gas Shale Fracturing: What Have We Learned?, (Society of Petroleum Engineers, Working Paper No. SPE 133456, 2010) ("No two shales are alike. Shales vary aerially and vertically within a trend, even along a well bore .... There are no optimum, one-sizefits-all . . . designs for shale wells."); see also HEATHER COOLEY \& CHRISTINA DONNELly, PAC. INST., HydRAULIC FRACTURING AND WATER RESOURCES: SEPARATING THE FRACK FROM THE FICTION 21 (2012) (detailing the variations in the composition of fracking fluids to compensate for the specifics of local geology and individual wells). 
wells. These risks vary with the depth of the shale bed, the size of the producing field, the depth of the water aquifer, the distance separating the producing field from the aquifer, the porosity of the rock between the shale and aquifer, the mix of chemicals used in fracturing, and the number of persons who draw water from the aquifer. ${ }^{345}$ There is also no one technology that can address these risks in a uniform way. ${ }^{346}$ It is possible that new technologies will emerge to address some of these risks, such as the development of non-toxic fracturing fluid that is cost effective. If so, it may be appropriate to ban toxic versions. ${ }^{347}$ Yet this sort of judgment cannot be made until the necessary technology has been developed and widely tested. In all of these efforts, industry groups can play a role by helping to formulate a set of best practices. ${ }^{348}$ Still, for these residual risks, some form of ex post regulation is needed, at least for now.

345. The State Review of Oil and Natural Gas Environmental Regulations (STRONGER), a nonprofit that has developed guidelines for state regulations, did not establish numerical criteria or uniform standards because "states vary too much in climate, geology, hydrology, topography, and other factors to be amenable to one-size-fits-all regulation." Memorandum of the STRONGER Bd. of Dirs., to Persons Interested in the Hydraulic Fracturing Guidelines (February 8,2010$)$, available at http://www.strongerinc.org/sites/all/themes/ stronger02/downloads/HF\%20Guideline\%20Web\%20posting.pdf; see also FIRST 2011 DOE REPORT, supra note 10, at 9 (noting that "shale plays in different basins have different geological characteristics" and that "[t]his geological diversity means that engineering practice and regulatory oversight will differ widely among regions of the country").

346. FIRST 2011 DOE REPORT, supra note 10 at 10 ("The realities of regional diversity of shale gas resources and rapid change in production practices and technology mean that a single best engineering practice cannot set for all locations and for all time.") (emphasis omitted).

347. See Joe Carroll, Chesapeake Testing 'Green' Fracking Fluids in Shale Wells, BLOOMBERG NEWS (Oct. 2, 2012, 3:23 PM), http://www.bloomberg.com/ news/2012-10-02/chesapeake-testing-green-fracking-fluids-in-u-s-shale-wells .html.

348. See, e.g., AM. Petroleum Inst., Overview of Industry Guidance / BEST PRACTICES ON HYDRAULIC FRACTURING (HF) (2012), available at http:// www.api.org/ /media/Files/Policy/Exploration/Hydraulic_Fracturing

InfoSheet.pdf; see also FIRST 2011 DOE REPORT, supra note 10, at 27 (recommending "creation of a shale gas industry organization dedicated to continuous improvement of best practice through development of standards, diffusion of these standards, and assessing compliance among its members") (emphasis omitted); SECOND 2011 DOE REPORT, supra note 144, at 9 (reiterating recommendation and noting that regional industry groups are taking regional approaches to best practices); infra notes $354-58$ and accompanying text (describing industry-NGO partnerships developing codes of conduct for shale oil and gas drilling). 


\section{Magnitude of Expected Harm}

The second factor, the frequency and severity of the harm, also varies with the pathway of contamination. Here again, certain activities present an obvious risk of significant harm if not controlled, such as dumping flow-back or produced water on the ground or into streams, drilling without protective well casings, or spilling toxic chemicals on the surface. These sorts of risks are either already regulated by best practices regulations, or if not, they should be.

Other risks appear to be more remote, such as the risk that either fracturing fluid or methane gas might migrate from shale seams into aquifers during fracturing. The evidence so far suggests that such incidents will be uncommon. Fracturing has been used for over sixty years to enhance production from conventional oil and gas wells, with only limited evidence of groundwater contamination. ${ }^{349}$ To be sure, fracturing in shale has a shorter history, but at least so far its track record does not seem to be different. According to a number of studies, there are no documented cases in which fracturing fluid has migrated into aquifers from deep shale seams or from wells for storing used fracturing fluid. ${ }^{350}$ Methane contamination of groundwater is more common, although it is often naturally occurring, so that only a subset of these incidents is caused by drilling. ${ }^{351}$ If such migrations of fracturing fluid and methane occur, how severe would they be? For now, it is impossible to make any categorical pronouncements. With fracturing fluid, for instance, the chemicals involved are a crucial variable. ${ }^{352}$ Some are a cause for concern even in diluted form, while others (e.g., biodegradable detergents) are less worrisome. Alleviating uncertainty about this variable is a good reason to require disclosure of chemicals used in fracturing, a subject to which we will return.

349. See, e.g., EPA, EVALUATION OF IMPACTS TO UNDERGROUND SOURCES OF DRINKING WATER BY HYDRAULIC FRACTURING OF COALBED METHANE RESERVOIRS 12 (2004), available at http://www.epa.gov/ogwdw/uic/pdfs/cbmstudy attach_uic_exec_summ.pdf; U.S. DEP'T OF ENERGY, STATE OIL AND NATURAL Gas Regulations Designed to Protect Water Resources 39 (2009), available at http://www.gwpc.org/sites/default/files/state_oil_and_gas_ regulations_designed_to_protect_water_resources_0.pdf.

350. See supra Part IV.A.1.

351. See supra Part IV.A.2.

352. For a list of chemicals commonly used in fracturing fluid, see What Chemicals Are Used, FRACFOCUS.ORG, http://fracfocus.org/chemical-use/what -chemicals-are-used (last visited Oct. 17, 2013). 
The risks whose severity are hardest to assess are those in which vibrations from fracturing disturb contaminants already in proximity to water sources, including pockets of methane near water wells or contaminants already at the bottom of water wells. This sort of event is hard to distinguish from naturally occurring contamination and, in any event, would not include (toxic) fracturing fluid.

Whatever the pathway, another important variable is the number of persons and properties affected by an episode of contamination. Water aquifers have finite dimensions, and are generally presumed to be isolated from other aquifers. ${ }^{353}$ If this is the case, the impact of any contamination will be localized. In some cases, however, a contaminated aquifer may be interconnected with other aquifers or with surface water. We do not know how common this is, ${ }^{354}$ or how far chemicals used in fracturing operations must travel before becoming sufficiently diluted not to affect water quality. Because of these uncertainties, there is some risk-most likely small but currently impossible to quantify - that contamination from fracturing could damage water over a significant area. Likewise, aquifers or surface waters that serve millions of people, such as the watersheds supplying New York City, pose a different level of risk and warrant more stringent regulation, as discussed further below.

Still another factor is whether the harm will be limited to property damage or will involve health effects. If contamination is detected early, injuries should be primarily economic; since alternative sources of water are available by truck or pipeline (at a price), the primary consequence should be a decline in property values. But if the harm is not detected early, so that it exposes people to toxic chemicals for an extended time period, there could be health effects that are significantly more costly.

353. See, e.g., Luke W. Harris \& Christopher J. Sanchez, Considerations for Analyzing Colorado Ground Water: A Technical Perspective, 15 U. DENV. WATER L. REV. 105, 121-22 (2011).

354. See Nathaniel R. Warner et al., Geochemical Evidence for Possible Natural Migration of Marcellus Formation Brine to Shallow Aquifers in Pennsylvania, 109 PROC. NAT'L ACAD. SCI. 11,961, 11,965 (2012) (detecting salinity in shallow groundwater in Pennsylvania which was present before fracturing operations began, and which did not include fracturing fluid chemicals, and thus probably was not caused by fracturing; concluding that this saline water, which resembles produced water, may have migrated naturally up from deeper areas over time, suggesting the presence of "a preexisting network of crossformational pathways that has enhanced hydraulic connectivity to deeper geological formations"). 


\section{Settlement Costs}

If we implement an ex post regulatory strategy for fracturing, how difficult will it be to determine who is responsible and who deserves compensation? In other words, how high will settlement costs be? Usually, the number of energy companies fracturing in a given locale will be small. Thus, identifying potential defendants should not be a problem. Proving they are causally responsible and have violated the applicable standard of care, though, is another matter. The legal issues posed by a liability regime could prove daunting, making ex post liability an expensive proposition.

A critical variable is whether the amount of injury per claimant-reflected in a loss in property values and possibly also in health effects-is sufficiently large to warrant individualized assessments. If water contamination goes undetected, resulting in significant exposure to livestock and humans, the potential damages could be large enough to warrant individualized adjudication. But if contamination is quickly detected and results in avoidance measures that prevent significant harm (like relocating water wells), the potential damages might be too small to sustain a liability regime. And of course, if significant time has elapsed between fracturing and the discovery of contamination, identifying a defendant sufficiently solvent to pay damages may be difficult. These considerations about the magnitude of settlement costs (relative to the amount in controversy) provide a reason to rely, at least in significant part, on command and control regulation rather than a pure liability regime.

The possibility that the settlement costs will be too large relative to the injuries sustained by claimants also suggests the need for some modifications in the common law, insofar as it is used to backstop best practices regulations. We discuss these issues in Part VI.

\section{Novelty of Risk}

As we have seen, ex ante regulation is more challenging with a novel technology (or a novel application of existing technology), because there is no baseline of existing precautions to define the "best practices" regulatory standard. With new technology (or new applications) there is thus a strong reason to rely at least in part on ex post regulation.

Neither fracturing nor horizontal drilling is a new technol- 
ogy. ${ }^{355}$ What is new is the application of this technology in shale. Thus, insofar as fracturing in shale presents water contamination risks identical to those in conventional oil and gas production--such as disposing of produced water, minimizing well casing leaks, and controlling blowouts-the risks and potential solutions are familiar, so this experience can support ex ante best practices regulation. Similarly, certain risks common to all fracturing sites-such as spills of fracturing chemicals on the ground and disposal of flow-back-are analogous to other activities that pose water contamination risks, and should also be amenable to best practices regulation.

However, ex ante regulation is much more difficult for pathways of contamination that are novel to fracturing. These include the risk that fracturing fluid or methane will migrate from shale seams to aquifers during fracturing, as well as the risk that vibrations from fracturing will disturb existing methane pockets near aquifers or stir up contaminants already at the bottom of water wells. For now, there is insufficient understanding of the frequency and magnitude of these risks, as well as how to minimize them, to support a system of ex ante regulation.

\section{E. THE REgUlatory StRATEGY FOR WATER CONTAMINATION FROM FRACTURING}

We are now in a position to draw these considerations together and propose in broad outline a regulatory strategy. In brief, we would rely on best practices regulation backstopped by liability, and we would tailor our liability rules to encourage compliance with, and development of, efficient best practices regulation.

\section{The Need for Both Best Practices Regulation and Liability}

As a core element of our regulatory strategy, best practices regulation offers three advantages. First, it is especially well suited to risks that are either common to all forms of oil and gas production or are familiar from other types of industrial operations, including surface spills, vertical well leaks, blowouts, disposal of produced water, and disposal of flow-back, as

355. Nicolas Loris, The Fracking Truth on Government's Role in Natural Gas Production, THE FOUNDRY (Jan. 31, 2012, 1:00 PM), http://blog.heritage .org/2012/01/31/the-fracking-truth-on-governments-role-in-natural-gas -production/ (stating that in the 1940s Stanolind Oil and Gas Corporation began testing of fracking and horizontal drilling). 
discussed above. Second, the idea that a public regulatory body is "on the case" is reassuring to the public. Given the enormous potential benefits of the shale boom, it is important to persuade the public that the practice is safe. Otherwise, we risk losing these potential benefits if, for example, an anti-fracking crusade marshals public support for a ban on fracturing. As a result, the entire industry has a strong stake in promoting public confidence in shale oil and gas drilling, and in assuring that actions of a few irresponsible companies do not jeopardize the entire industry. Third, because energy companies must make substantial investments to drill in shale, they need to estimate what regulatory costs they will face. Best practices regulation offers this predictability. ${ }^{356}$

However, best practices regulation has three important drawbacks, so that it must be backstopped by liability. First, best practices regulation is only as effective as the resources committed to enforcing it. If budget cutbacks result in irregular inspections and legislative inaction allows the real value of fines to erode, energy companies will have diminished incentives to comply. ${ }^{357}$ Second, best practices regulation is ineffective for heterogeneous or novel risks. As a result, risks that are unique to fracturing of shale seams and have no clear analogous counterpart in other operations should be regulated ex post with liability rules. This includes the risks, discussed above, of migration from shale seams and of disturbance of existing contaminates near water sources. This is not to suggest that these risks would remain forever in the ex post camp. As we learn more about these risks, we presume industry will develop ways of minimizing them, at which point they can move to the best practices column. Third, as we have seen, command and control regulation provides relatively poor incentives to develop new risk-minimizing innovations. Liability rules provide a much more powerful incentive in this regard.

356. Of course, energy companies may prefer best practices regulations for less laudable reasons, such as imposing costs on potential new entrants and competitiors, shifting blame to the regulator if things later go wrong, and so forth.

357. Even after a recent comprehensive revision in its oil and gas law, Pennsylvania caps civil penalties for violations of best practices regulations at $\$ 75,000$ plus $\$ 5,000$ per day for each day the violation persists. 58 PA. STAT. $\S 3256(2013)$. 
2. Three Rules to Coordinate Liability with Best Practices Regulation

The two anchors of our regulatory strategy-best practices regulation and liability-should be coordinated, so that liability standards vary depending on whether a best practices regulation governs the conduct that caused the contamination. Specifically, we envision three different liability rules depending on compliance with best practices regulations. First, any water contamination causally attributable to the violation of a best practices regulation should be considered negligence per se and should result in liability.

Second (and conversely), any claim that water contamination was caused by the failure of an energy company to adopt a measure more protective than required by an applicable best practices regulation should generally be defeated by a regulatory compliance defense (although we would include an exception for best practices regulations that are significantly less protective than comparable rules in other jurisdictions). These two per se rules, working in tandem, create a powerful incentive for industry to support the development of protective best practices rules and to comply with them.

The third rule fills any gaps left by the first and second: if the water contamination is causally attributable to the defendant's fracturing, but cannot be linked to an activity governed by a best practices rule, we would apply a version of the doctrine of res ipsa loquitur. In such a regulatory vacuum, proof that the energy company caused the contamination would create an inference that the firm was negligent, shifting the burden to the company to prove it exercised reasonable care. In effect, the energy company would have to show that the contamination was an inevitable accident that could not be prevented by any exercise of reasonable care. Because this showing would be very difficult, the standard of care, as a practical matter, would approach strict liability. This high probability of liability for harms not covered by best practices regulations would give energy companies a strong incentive to learn how to reduce the residual risks not governed by best practices regulations and to help regulators develop new best practices regulations.

3. The Supporting Role of Prohibitions, Disclosure, and Coasean Bargains

Our proposed strategy would not ignore the other modes of regulation we have discussed, but each would play a subordi- 
nate role. Although we would not rely on prohibitions as the principal strategy, they are appropriate where risks are especially great. In New York State, for example, we would ban fracturing near the Catskill and Croton watersheds that supply virtually all of New York City's water. ${ }^{358}$ The expense of developing an alternative source of water for millions of people on short notice would be massive. Even a small risk of this costly scenario should be ruled out; if the risk assessment changes over time, then the ban can be reconsidered later.

Information disclosure would also play an important if secondary role. Mandatory disclosure becomes more important over time as we learn which information is crucial. We already know, though, that blowouts and leaks should be disclosed, as well as the chemicals used in fracturing fluid. Indeed, many companies have begun voluntarily disclosing the composition of their fracturing fluid, and a nonprofit has compiled some of this information in a searchable database. ${ }^{359}$ Many states have begun requiring disclosure, and EPA (under the Toxic Substances Control Act) and the Bureau of Land Management are also developing federal disclosure standards. ${ }^{360}$

A more ambitious information disclosure strategy would be to require regulators to prepare an environmental impact

358. The New York City water supply originates in the Catskill Mountains and Hudson River Valley, an area of over 1900 square miles within dozens of counties, towns, and villages. The watershed-and the city's drinking water specifically-is protected by a 1997 Memorandum of Agreement, which created a watershed partnership council and series of regulations on water quality throughout the watershed. N.Y. DEP'T OF STATE, NEW YORK CITY WATERSHED MEMORANDUM OF AGREEMENT, ARTICLE I (1997), available at http://www .dos.ny.gov/watershed/nycmoa.html. See also ARTHUR, URETSKY \& WILSON, supra note 155, at 10 (noting that Catskill and Croton Watersheds supply all water to New York City and the surrounding area, including Northern New Jersey).

359. See New Website Makes Information on Fracking Chemicals More Accessible to the Public, CTR. FOR EFFECTIVE GOV'T (Nov. 27, 2012), http://www foreffectivegov.org/new-website-makes-info-on-fracking-chemicals-more -accessible (discussing a new searchable website launched by SkyTruth); What Chemicals Are Used, supra note 352.

360. Oil and Gas; Well Stimulation, Including Hydraulic Fracturing on Federal and Indian Lands, 77 Fed. Reg. 27,691 (proposed May 11, 2012) (to be codified at 43 C.F.R. pt. 3160) (development of new BLM standards); ARNOLD \& PoRTER LLP, AdDitional Fracking Chemical Substance REPorting REQUIREMENTS UNDER TSCA MAY FURTHER COMPLICATE LANDSCAPE (2012), available at http://www.arnoldporter.com/resources/documents/Advisory\% 20Additional_Fracking_Chemical_Substance_Reporting_Requirements_

Under_TSCA_May_Further_Complicate_Landscape.pdf. For a discussion, see infra Part VI.A.1.b. 
statement (EIS), along the lines of the federal NEPA process, before issuing any permission to drill that contemplates the use of fracturing. This would require consideration of all environmental impacts-road damage, noise, water usage, habitat destruction, and induced earthquakes, as well was water contamination-before production commences. Proposed alternatives that would mitigate harms along each of these dimensions could be explored, which might lead to beneficial modifications. Public participation would be possible, either in the form of comments on a draft impact statement or in one or more public hearings. And information about impacts and mitigating alternatives for each project could be assembled in a large database, providing feedback to regulators in developing new best practices regulations. ${ }^{361}$

Experience with the federal NEPA program, nevertheless, suggests strong reasons for caution about mandating such an ambitious information disclosure program for every application for permission to drill. The full-blown EIS process is very expensive. ${ }^{362}$ The discussion of impacts and alternatives usually requires hiring an environmental consulting firm, which adds considerably to the expense of any energy project. Responding to comments entails further diversion of staff resources by regulatory bodies. To the extent that compliance with disclosure requirements is enforced through judicial injunctions, the costs mount even higher. Moreover, the threat of injunctions transforms the benign-sounding information disclosure regime into a weapon for delay by disgruntled opponents, driving up the costs of projects even further and often forcing cancellation of otherwise beneficial undertakings. ${ }^{363}$ Enforcement through injunctions also has the effect of shifting de facto authority over production decisions from landowners, production companies, and regulators to environmental organizations and judges, who may have relatively little perspective on the larger societal interests at stake. Perhaps the most decisive objection, however, is that one cannot take a "hard look" at the environmental conse-

361. Federal NEPA rather notoriously includes no provision for follow-up monitoring. Bradley C. Karkkainen, Toward a Smarter NEPA: Monitoring and Managing Government's Environmental Performance, 102 COLUM. L. REV. 903,908 (2002).

362. See Robert V. PERcival et al., ENVIRONMENTAL Regulation: LAW, SCIENCE, AND POLICY 930-34 (6th ed. 2009), and sources cited therein.

363. For an instructive case study, see William W. Buzbee, The Regulatory Fragmentation Continuum, Westway, and the Challenges of Regional Growth, 21 J.L. \& POL. 323 (2005). 
quences of fracturing, as recently mandated by a federal magistrate judge in California, ${ }^{364}$ until we have more experience telling us what those consequences are. ${ }^{365}$ Information disclosure only works when there is information-as opposed to speculation-to disclose. ${ }^{366}$

We also view Coasean bargains as an appropriate regulatory strategy. Given the uncertainty about water contamination risks, it is unrealistic to expect landowners and energy companies systematically to engage in negotiations about allocating these risks by contract, although as previously noted, there is evidence this is beginning to happen in some lease negotiations. The problem is not just the familiar one of asymmetric information, but the concern that neither the energy companies nor the landowners have definitive information about the nature and magnitude of the risks. We therefore expect at least some parties to be reluctant to allocate these risks by contract. Yet the process should become easier with time and experience.

One promising development is that energy companies have begun working with environmental organizations to formulate private codes of best practices. For example, the Center for Sustainable Shale Development-a joint venture of energy companies with NGOs such as the Environmental Defense Fundoffers certification to energy companies whose drilling practices meet their standards. ${ }^{367}$ This initiative is analogous to LEED certification for green buildings. ${ }^{368}$ It gives landowners a

364. Ctr. for Biological Diversity v. Bureau of Land Mgmt., No. C 11-06174 PSG, 2013 WL 1405938 (N.D. Cal. Mar. 31, 2013).

365. The Energy Policy Act of 2005 creates a "rebuttable presumption" that certain oil and gas development and production activities on federal lands are categorically excluded from NEPA. Energy Policy Act of $2005 \S 390$, P.L. 10958, 119 Stat. 594, 747-48. Examples of excluded activities include surface disturbances of less than five acres and drilling within five years of previous drilling activity. Id. $\S 390(\mathrm{~b})(1),(2)$. These exclusions were apparently not at issue in Center for Biological Diversity. See generally, Ctr. for Biological Diversity, 2013 WL 1405938, supra note 364.

366. Magistrate Judge Grewal's opinion in Ctr. for Biological Diversity, acknowledges that water contamination is the most serious environmental issue. But rather than citing any concrete evidence supporting a risk of water contamination, he relies heavily on the existence of "public controversy" as a reason to delay fracturing on public lands until a new EIS is completed. Ctr. for Biological Diversity, 2013 WL 1405938, supra note 364, at*11-15.

367. CTR. FOR SUSTAINABLE SHALE DEV., http://www.sustainableshale.org/ (last visited Oct. 17, 2013).

368. How to Certify a Building Project, USGBC LEED, http://www.usgbc .org/leed/certification (last visited Oct. 17, 2013) (describing process for securing LEED certification for green buildings). 
straightforward way to require best practices when negotiating a mineral rights lease: instead of having to specify various practices, they can simply require certification. Similarly, the International Energy Agency has developed a set of "Golden Rules for a Golden Age of Gas. ${ }^{\text {"69 }}$ This sort of initiative is a useful supplement for best practices regulation and liability, and could ultimately reduce the need for such regulation.

\section{DESIGNING A REGULATORY REGIME FOR WATER CONTAMINATION}

In this Part, we offer more detail about our proposed regulatory regime, focusing on the design of the liability rule and its interaction with best practices regulations. We also consider other features, including comparative negligence, the measure of damages, attorneys' fees, and the risk of insolvency. The next Part addresses institutional options for implementing these features, including who should establish the best practices regulations.

\section{A. Causation}

In designing the liability system, we begin with causation, which we regard as the most crucial issue. We distinguish three questions. First, did oil or gas production cause the water contamination? If not, there should be no liability. Second, what was the pathway of the contamination? Third, what was the scope of the harm caused by the contamination? Did it impair the value of property by rendering the water supply useless? Did it cause further harm to vegetation, livestock or human health?

\section{Contamination Injury}

For energy companies to have the right incentives, they should be liable only if they actually cause harm. ${ }^{370}$ Thus, plain-

369. Int'l Energy Agency, Golden Rules for a Golden Age of Gas, WORLD ENERGY OUTLOOK (May 29, 2012), available at http://www.worldenergyoutlook .org/goldenrules/.

370. In theory, one could impose liability for imposing not just harm, but also a risk of harm. But this risk of contamination would be virtually impossible to calculate. If one imposed liability for risk of harm, it would also be necessary to reduce recoveries in all cases to expected damages, in order to avoid over-deterrence. This, too, would be very difficult to calculate. Over a large enough number of cases, imposing liability only for actual harm generates the same aggregate liability as expected harm, and it has the added virtue of providing full compensation to those who are actually injured, as opposed to 
tiffs should be required to prove by a preponderance of the evidence that fracturing was a but-for cause of water contamination on their property. ${ }^{37}$

This showing is challenging for three reasons. First, if the plaintiff's water well contains an unusual chemical, how do we know it comes from fracturing, as opposed to a natural cause or some other source of pollution? Even if the plaintiff's water contains methane, how do we know it was not naturally present in the water? Second, if several energy companies are fracturing in a given locale, how do we know which one is responsible? Third, what if contamination is discovered years after energy companies have stopped fracturing in a particular locale? How do we know whether the contamination comes from a longclosed oil or gas well or some other source? These questions are difficult because the parties have only limited information. After all, fracturing occurs deep underground, and aquifers are also underground (though much closer to the surface), so neither can be observed directly from the surface.

To generate reliable answers to these questions, the liability regime should create incentives to develop better information. We suggest three ways to pursue this "information forcing" goal, ${ }^{372}$ ranked in order of importance: baseline testing;

those who experience near misses.

371. Our focus is on cause-in-fact-in effect, "but-for causation"--and not on the narrower concept of proximate cause, which asks whether a cause-infact was sufficiently direct or foreseeable or otherwise relevant to the policies pursued by the liability regime. One can imagine issues of proximate cause arising. For example, suppose A is engaged in fracturing under B's land, and B digs an extremely deep water well that reaches the shale bed, and thus becomes contaminated with fracturing chemicals. Here, there is no doubt that A's fracturing activity is a cause-in-fact of the water contamination. Nevertheless, the water well's unusual depth would probably be regarded as superseding cause of the injury, such that A's drilling would likely not be treated as a proximate cause. Or suppose fracturing by $\mathrm{C}$ sets off weak vibrations on the surface, causing explosives stored in a cabin miles away to fall off a shelf and explode. Here too, the fracturing is a cause-in-fact of the explosion, but it is not foreseeable and thus is unlikely to be regarded as a proximate cause. These hypotheticals suggest that proximate cause issues will arise only in unusual circumstances. We therefore put issues of proximate cause to one side, and assume that they can be resolved using the doctrinal tools developed in ordinary tort suits.

372. See, e.g., Bradley C. Karkkainen, Information Forcing Environmental Regulation, 33 FLORIDA ST. U. L. REV. 861 (2006). Information forcing can be considered a variant on "action forcing," which has long been a centerpiece of environmental regulation, for example, under NEPA. See Kleppe v. Sierra Club, 427 U.S. 390, 409 (1976) (describing NEPA's requirements as "actionforcing provisions intended as a directive to all agencies to assure consideration of the environmental impact of their actions in decisionmaking") (internal 
disclosure; and tracer chemicals.

\section{a. Baseline Testing}

The most important step is to test groundwater before fracturing begins in order to establish a benchmark of water quality. Then, if an allegation of contamination is made, the water would be tested again. If contaminants are found that were not present in the baseline sample, this would support the allegation that fracturing caused the contamination. Conversely, if the contaminants were already there, this would powerfully rebut such a claim. ${ }^{373}$ In illuminating causation in this way, baseline testing is the most important information forcing strategy we propose. A number of states have recognized the value of baseline testing and have moved to require or encourage it. ${ }^{374}$

Baseline testing has four limitations. First, its inferential value erodes over time. If contamination is found one year after baseline testing was conducted, the inference of causal responsibility is strong. But if contamination is found twenty years later, the inference is much weaker. Over twenty years, the water could have been contaminated in many ways having nothing to do with fracturing. A solution to this problem would be periodic testing, which has the further advantage of alerting landowners to emerging water quality problems, thereby reducing risks to health that otherwise could arise from contamination. Of course, periodic testing increases the cost of any testing program.

Second, the inferential value of baseline testing also diminishes with distance. The farther a water well is from fracturing, the less likely it is that fracturing has caused any water contamination. So how close must fracturing be to water in order for baseline testing to be required? Obviously, a longer distance

quotation marks omitted).

373. See FIRST 2011 DOE REPORT, supra note 10, at 23 ("Availability of measurements in advance of drilling would provide an objective baseline for determining if the drilling and hydraulic fracturing activity introduced any contaminants in surrounding drinking water wells.").

374. Wiseman, supra note 163 , at 157-58 (discussing regulations in Colorado, Louisiana, Michigan, Ohio, West Virginia, Oklahoma and Pennsylvania). Two states (Pennsylvania and West Virginia) have sought to encourage baseline testing by adopting a rebuttable presumption that, if the testing is not done before drilling, water contamination within a certain time and distance of a fracturing operation was caused by the operator. Id. at 158 . Wyoming is also likely to require baseline sampling. Mark Wilcox, Baseline Water Testing Moves Forward, WYo. BUS. REP., June 12, 2013, http://www .wyomingbusinessreport.com/article.asp?id=65090. 
means more water wells have to be tested, and thus higher costs.

Third, baseline testing cannot be conducted if landowners do not allow access to their water wells. They might be motivated by a desire for privacy or, for that matter, by a concern that any negative information they learn would have to be disclosed when they sell their property. Whatever their reasons, if landowners refuse to consent to a baseline test, they should pay a price for doing so. We would require them to overcome a presumption that the drilling activity did not cause the contamination. Or if a stronger incentive is needed, we can bar them from bringing suit.

Fourth, baseline testing does not prevent certain types of litigation-related misconduct. For instance, landowners might deliberately pollute their own land after the test in order to seek damages in a lawsuit and, correspondingly, energy companies might introduce pollutants before the test. We think it will be rare for landowners to foul their own nest by destroying their water supply or for energy companies to risk liability for this sort of willful misconduct, but we recognize the possibility. If it happens, the parties would be free to introduce evidence of the other side's misconduct; admittedly, though, this effort may prove costly and may not always succeed. To deter this sort of misconduct, therefore, we should deem any such tampering a criminal offense subject to severe penalties.

Notwithstanding these four limitations, we believe the cost of baseline testing is justified. We say this even though it is possible that a large scale program will seem wasteful if fracturing turns out to present little or no danger, as its proponents maintain. Yet even in this best case scenario, testing offers the significant advantage of allaying public anxiety about fracturing, as well as the collateral benefit of educating landowners about the quality of their water. Of course, if incidents of contamination do occur, testing becomes all the more valuable. It reduces the risk of health effects by ensuring that contamination is detected, while also increasing the accuracy and reducing the cost of adjudicating disputes.

Moreover, while the cost of performing these tests is not trivial, it is modest compared with the revenue generated by a successful oil or gas well. ${ }^{375}$ We assume the energy company

375. The cost of performing the test is likely to be between $\$ 200$ and $\$ 1500$ per well, depending upon which analytes (and how many) are included in the test. There would be further costs in hiring professionals to gather samples. 
would fund the baseline test (for instance, as a condition of receiving permission from the state to drill). For successful oil or gas wells, companies presumably would pass on some or all of this cost-as well as the costs of any periodic testing-to leaseholders through adjustments to the royalty. It may also be possible to contain costs, for instance, by testing only wells that are quite close to fracturing, or by gathering samples only from some, but not all, water wells in an area, if they draw on the same aquifer. ${ }^{376}$ Landowners who prefer more comprehensive testing can negotiate for it in return for a reduced royalty. Adjustments can be made over time as we develop a better understanding of the risks.

\section{b. Disclosure of Fracturing Chemicals}

We should also require disclosure of all chemicals used in fracturing fluid, a step taken voluntarily by many companies and now required in a number of states. ${ }^{377}$ When paired with baseline testing, disclosure can make determinations of causation more accurate, at least when the claim is that fracturing fluid caused the contamination. ${ }^{378}$ For example, assume that plaintiffs find hydrochloric acid in a water well, and that baseline testing did not show any hydrochloric acid before fracturing began nearby. If the energy company discloses that its fracturing fluid contains hydrochloric acid, a court will likely conclude that fracturing caused the contamination.

We thank our colleague, Mike Gerrard, as well as Nelson Johnson of Arnold \& Porter LLP, for this estimate.

376. If fracturing occurs in an area where there are no existing water wells, baseline testing would be far more expensive. We would rely on the appropriate regulatory authority to develop local rules addressing this situation. In these circumstances, we would also recognize a general privilege on the part of energy companies to engage in baseline testing, at their own expense, should they wish to do so as a form of assurance against future unfounded claims.

377. Kate Galbraith, Seeking Disclosure on Fracking, N.Y. TIMES, May 30, 2012, http://www.nytimes.com/2012/05/31/business/energy-environment/ seeking-disclosure-on-fracking.html?_r=0 (noting that Texas, Pennsylvania, Wyoming, Arkansas, Colorado, Montana, Oklahoma and Ohio all require disclosure, and that Ohio legislature had approved mandatory disclosure as well). For a discussion of voluntary disclosure by companies, see supra note 314 .

378. This disclosure is less helpful with contaminants other than fracturing fluid, such as methane or other naturally occurring contaminants. Also, a potential downside is that disclosure might inadvertently facilitate fraud by potential plaintiffs. Someone who wishes to add pollutants to their own water in order to collect damages in a law suit (or an energy company that wishes to embarrass a competitor) is better able to do so if they know what chemicals to add. Yet our hope is that this sort of misconduct would be rare, and all the more so if deterred with criminal penalties, as discussed above. 
Disclosure of fracturing chemicals has other benefits as well. It should also encourage energy companies to minimize the use of toxic or carcinogenic ingredients, if satisfactory substitutes are available. Likewise, landowners may respond by negotiating for limits on the use of these substances (e.g., if nontoxic fracturing fluid proves to be viable). In addition, knowledge of the chemicals will assist physicians in treating individuals who have been exposed to fracturing fluid.

Disclosure of fracturing chemicals is also cheap to administer. Energy companies know what chemicals they use, and would be required to share this information with the relevant regulator or post it on a website. Regulators would have to ensure that the disclosure is accurate, so the main expense here is to fund enforcement.

The primary objection to disclosure is that the composition of each energy company's fracturing fluid is a trade secret. While confidential disclosure to regulators would not destroy a trade secret, disclosure to the public is more of an issue. Even then, however, the trade secret would not necessarily be compromised if companies were required to disclose only the ingredients in their fluid, but not the quantities or proportions used. ${ }^{379}$ The critical question is whether companies will continue to try to improve fracturing fluid-making it safer and more effective-if they have to share innovations with competitors. We believe they will, if only to reduce their potential liability for contamination. If so, then mandatory disclosure has the advantage not just of reassuring the public and making liability determinations more accurate, but also of helping more energy companies learn about risk-reducing innovations. ${ }^{380}$ Moreover,

379. We thank Mike Gerrard for this observation. Also, if the recipe is sufficiently novel to be patented, mandatory disclosure would not eliminate the energy company's right of exclusive use. But we have encountered no reference to patented chemical mixtures in the literature, and it seems unlikely that alterations in the use and proportions of existing chemical additives would satisfy the standard of nonobviousness required for a patent. See Sara DastgheibVinarov, Comment, A Higher Nonobviousness Standard for Gene Patents: Protecting Biomedical Research from the Big Chill, 4. MARQ. INTELL. PROP. L.REV. 143, 151-153 (2000).

380. If government-mandated disclosure destroys a trade secret, this cost would be borne by the government-not by the energy company-if it qualifies as a taking of property. The Supreme Court has held that mandatory disclosure of trade secrets can be a taking under the Fifth Amendment. Ruckelshaus v. Monsanto Co., 467 U.S. 986, 987-88 (1984). The Court has distinguished between disclosure of trade secrets associated with existing operations (which can be a taking) and disclosure that is required to receive a permit for new operations (which is not a taking because applying for a permit is treated 
even if mandatory disclosure discourages innovation, the added reassurance to the public is probably of greater benefit in terms of securing the future of this form of production.

\section{c. Tracer Chemicals}

A third information forcing strategy would require energy companies to include tracer chemicals in their fracturing fluid-a kind of DNA testing for fracturing. ${ }^{381}$ Each energy company would include a unique but harmless and nondegradable chemical in their fracturing fluid, and would register it with the relevant regulator. If water contamination is alleged, the water would be tested for this chemical marker. If it is found, the energy company's fracturing fluid probably caused the contamination; if not, it presumably did not. ${ }^{382}$

Tracer chemicals would be especially helpful when baseline testing and disclosure do not provide enough certainty about causation-for instance, when contamination occurs at some distance from fracturing, when contamination is alleged years after fracturing took place, or when more than one energy company is operating near the water.

In theory, landowners eager to bring a law suit could inject tracer chemicals into groundwater, while also contaminating their own water to establish liability. Similarly, there is the risk that one energy company would try to use another's tracer chemicals to deflect blame for any contamination it causes. As discussed above, this sort of misconduct would hopefully be rare, and should be deterred with criminal penalties.

Another objection to tracer chemicals is grounded in feasibility and cost. Many industry participants believe that it would be relatively easy to identify enough chemicals with the required criteria-unique, harmless, nondegradable, detectable-making a rule requiring the use of tracer chemicals feasible and relatively inexpensive. But this remains to be demonstrated. If the idea proves feasible, there will nevertheless be costs associated with registering the chemicals and enforcing

as a waiver of trade secret protection). Id. Assuming this reasoning is followed, states that mandate disclosure only prospectively for new oil and gas wells should not be liable.

381. Chris Mooney, The Truth about Fracking, 305 SCI. AM. 80, 80-85 (2011) (describing the introduction of tracers into fracking fluid mixtures as "relatively easy," but facing industry opposition).

382. Like disclosure of the ingredients in fracturing fluid, tracer chemicals are less helpful with contaminants other than fracturing fluid, such as methane or other naturally occurring contaminants. 
the relevant rules. ${ }^{383}$

To sum up, then, baseline testing and disclosure go some distance in resolving issues of causation, and tracer chemicals could help as well. More generally, since the problem here is inadequate information, the solution should be to generate more information.

\section{Pathway of Causation}

Once the plaintiff establishes that fracturing activity caused the contamination, the next issue concerns how the water was contaminated-and, in particular, whether the pathway of contamination was governed by best practices regulations. As we detail more fully in the next subpart, we would apply different liability rules depending on whether the pathway is governed by best practices regulations. Consequently, it is important to make a determination about the pathway of contamination.

We suspect that direct proof of the pathway of contamination will be possible only in a subset of cases. We would allow either party to introduce such evidence. For example, if the plaintiff can show that the contamination was caused by a blowout, the plaintiff may then be able to prove that the energy company violated best practices regulations governing blowout preventers. If the defendant can show that a blowout did not cause the contamination, its compliance with the regulations prescribing blowout preventers would be irrelevant.

In many cases, the evidence will not reveal exactly how the water was contaminated, and thus whether a best practices regulation addressed the relevant conduct in the case. In these circumstances, we would rely on rebuttable presumptions of causation. Specifically, if the plaintiff proves both (1) that fracturing caused the contamination and (2) that the energy company violated a best practices regulation governing a particular pathway of contamination, we would create a presumption that this was the pathway of contamination. ${ }^{384}$ The energy company

383. We would not impose a requirement of using tracer chemicals until its feasibility has been fully vetted. But the idea is sufficiently promising that the oil and gas industry, or perhaps the Energy Department or EPA, should undertake a study examining its benefits and costs. If doubts about feasibility remain, it could be implemented on a pilot basis.

384. This is analogous to what Ken Abraham calls "self-proving causation," Kenneth S. Abraham, Self-Proving Causation (Univ. of Va. Law Sch. Research Paper Series, September 2013), available at http://ssrn.com/abstract= 2320596 , although we would ground the inference of causation in the violation 
would be free to rebut this presumption. For example, assume that baseline testing reveals that contaminants emerged after drilling began, and that the plaintiff establishes that the well casing was an inch thinner than the regulations require. Unless the energy company can show otherwise, we would presume that this violation of the well casing rule caused the contamination. Alternatively, if the energy company shows that it was in compliance with applicable best practices regulations governing a particular pathway of contamination, and there is no evidence it was otherwise negligent with respect to this pathway of contamination (e.g., the well casing is sufficiently think and deep and was set properly), we would create a presumption that this was not the pathway of contamination. This, too, would be subject to rebuttal by the plaintiff.

The difficult cases fall in the residual category-where (1) the plaintiff can prove that fracturing caused contamination, (2) there is insufficient direct evidence of the pathway of contamination, and (3) no presumption based on best practices regulations is available to identify the pathway of contamination. In these cases, we would adopt a rebuttable presumption that the contamination was caused by a pathway not governed by any best practices regulation. As we discuss further below, we would adopt a rule similar to res ipsa loquitur in such cases.

\section{The Scope of the Harm}

Once landowners have established that fracturing has caused water contamination, and the tribunal has determined the pathway of contamination, it is necessary to determine the scope of the harm. In nearly all cases, the contamination will have caused property damage. In addition, contamination that goes undetected for some time might also have caused more serious injuries. The landowner might have irrigated crops or other vegetation that were damaged, or hydrated cattle that were sickened. Or the landowner and her family might have consumed the water, developing health problems or, in the worst case, cancer or some other potentially fatal disease.

In establishing any of these more severe harms, plaintiffs face an uphill battle. Proving harm from exposure to chemicals is uniquely challenging. ${ }^{385}$ Extensive expert testimony is needed

of the best practices regulation rather than in a finding of negligence.

385. See, e.g., PETER Schuck, Agent ORANGe ON Trial: MASS TOXIC DisASTERS IN THE COURTS (1986); Kenneth S. Abraham, Individual Action and Collective Responsibility: The Dilemma of Mass Tort Reform, 73 VA. L. REV. 
to identify which chemicals are hazardous, drawing on epidemiological data, animal studies, or molecular comparisons. Experts also have to develop a dose-response curve relating different levels of exposure to the probability of harm, and they have to show the extent and scope of the plaintiff's exposure. All of this expert testimony is expensive, and serious concerns have been raised about whether it is within the comprehension of judges and juries. ${ }^{386}$

Nor is an information-forcing strategy available to increase the reliability and reduce the cost of these judgments. After all, although a reliable and relatively inexpensive baseline test can be performed for water quality, the same cannot be said for human health.

Instead, the best we can do may be to establish additional presumptions. In the common law, for example, if we know a plaintiff's injury was caused by either A or B, but we do not know which, there is a presumption of joint causation, in effect forcing defendants to show they are not responsible. ${ }^{387}$ Similarly, CERCLA establishes four categories of "potentially responsible parties," who are presumed to be causally responsible for contamination of a hazardous waste site. ${ }^{388}$

By analogy, in deciding whether exposure to water contamination caused further injury, we could rely on EPA guidance under the Safe Drinking Water Act (SDWA). Specifically, EPA has established a series of maximum contaminant levels (MCLs) for a variety of chemicals found in drinking water. These regulatory standards apply only to public drinking water supply systems, and hence do not directly regulate private water wells drawing on groundwater-the situation of principal concern here. Nevertheless, the MCLs can be adopted as a kind of shorthand for resolving disputes about exposure injury from

\section{5 (1987).}

386. The Supreme Court has held that in federal cases, trial judges must serve as gatekeepers excluding expert testimony that is not grounded in studies that have been peer reviewed and published. Daubert v. Merrell Dow Pharm., Inc., 509 U.S. 579, 593-94 (1993).

387. Summers v. Tice, 199 P.2d 1, 4 (Cal. 1948).

388. They are current owners and operators of the site; owners and operators of the site when the wastes were deposited; persons who arranged for the deposit of wastes at the site; and persons who transported the wastes to the site. 42 U.S.C. $\$ 9607$ (a) (2006). For qualifications of the rule of joint and several liability, see Burlington N. \& Santa Fe Ry. Co. v. United States, 556 U.S. 599, 616 (2009); Aaron Gershonowitz, The End of Joint and Several Liability in Superfund Litigation: From Chem-Dyne to Burlington Northern, 50 DUQ. L. REV. 83 (2012). 
contaminated private wells. Specifically, (1) if an energy company has increased the concentration of a chemical in a water well; (2) the concentration exceeds the applicable MCL under the SDWA; (3) the landowner has been exposed to the water for an appreciable period of time (e.g., at least one year); and (4) the landowner has experienced an injury associated by EPA with exposure to the chemical, then a presumption would arise that exposure to the chemical caused the injury. The burden would shift to the energy company to rebut the presumption.

Admittedly, our proposal may leave gaps unfilled. Although EPA has established a large number of MCLs for a wide range of chemicals found in drinking water, it is conceivable that fracturing could give rise to contamination by a chemical not covered ${ }^{389}$ In addition, the MCLs are established with a view to human health effects, which may not translate easily to vegetation or livestock.

A more general concern, of course, is that such presumptions are an inherently imperfect mechanism. Yet without such a presumption, a health effects claim would entail prohibitive costs, which would be impractical except, perhaps, in a large class action. If the liability system is to provide meaningful recovery for exposure injury - and thus a meaningful incentive to avoid this type of harm-some kind of shortcut, such as the proposed presumption, is needed.

To be sure, the presumption creates a risk of subjecting energy companies to liability for health effects they did not cause, and thus of deterring socially valuable economic activity. Yet energy companies can mitigate this risk with self-help. By periodically testing the water, as recommended above, they can either ensure that it is not contaminated or act promptly (e.g., within a year) to clean or replace it if it is. After all, energy companies cannot be liable for health effects unless there first is a showing that they contaminated the water.

\section{B. STANDARD OF CARE}

Once issues of causation are resolved, it is necessary to specify the standard of care we will use to evaluate the energy company's conduct. Most discussions assume there are two options: strict liability and negligence. Under strict liability, defendants must offer compensation for any harms they cause.

389. Current EPA regulations list MCLs for 79 chemicals. 40 C.F.R. $\S \S 141.61-.65$ (2012). 
Under negligence, by contrast, defendants are liable only if they fail to take reasonable precautions. Under the so-called Hand formula, they are negligent (and thus liable) if (a) the marginal benefits of the untaken precaution (in terms of reduction in the probability or severity of the harm) are greater than (b) the marginal costs of taking the precaution. ${ }^{390}$

\section{Our Hybrid Proposal}

In contrast, we recommend a hybrid approach that, in form, is based on negligence, but as a practical matter would function like strict liability in many circumstances. Our main goal in offering this hybrid approach is to integrate best practices rules with the liability regime. Specifically, we recommend adopting a negligence framework requiring energy companies to conform to a standard of reasonable care that would be defined in significant part by best practices regulations.

Thus, we would apply three different standards of care depending on the circumstances: First, violation of best practices regulations would establish negligence per se (which functionally resembles strict liability). Second, compliance with best practices regulations would establish a (qualified) regulatory compliance defense. Third, if no best practices regulations govern the problem leading to the contamination-or, relatedly, if it is impossible to identify how the contamination occurred-we would apply the doctrine of res ipsa loquitur, which would, for practical purposes, function much like strict liability. Thus, although we are advocating a rule that is negligence-based in form, the practical effect is a combination of a regulatory compliance defense with what otherwise is in function (if not in form) strict liability (i.e., when energy companies violate best practices regulations or when no best practices regulation governs the cause of the contamination).

\section{Comparison of Strict Liability, Negligence, and Our Hybrid Proposal: Five Factors}

To explain this recommendation, we should step back and

390. The "Hand formula" derives from an algebraic formulation of negligence developed by Judge Learned Hand in United States v. Carroll Towing Co., 159 F.2d 169 (2d Cir. 1947). As Judge Posner explains, "If . . . the benefits in accident avoidance exceed the costs of prevention, society is better off if those costs are incurred and the accident averted, and so [injurers are] made liable, in the expectation that self-interest will lead [them] to adopt the precautions in order to avoid a greater cost in tort judgments." Richard A. Posner, A Theory of Negligence, 1 J. LEGAL STUD. 29, 33 (1972). 
evaluate how strict liability and negligence-and, for that matter, our hybrid proposal-compare on five dimensions: the incentive they create for defendants to take precautions; decision costs; the incentive for defendants to modulate the level of their activity; the incentive of plaintiffs to take precautions; and the interaction with best practices regulations.

\section{a. Incentive to Take Precautions}

Strict liability and negligence are thought to create essentially the same incentive for defendants to take efficient precautions (as, of course, would a hybrid of the two). ${ }^{391}$ Under negligence, defendants will take precautions as long as the marginal cost is lower than the expected harm (or, otherwise, they will be liable). They will do the same under strict liability, since their choice is either to take the precaution or to pay the damages, and they will presumably choose the course that is less expensive. ${ }^{392}$

\section{b. Decision Costs}

With respect to decision costs, negligence and strict liability potentially diverge. ${ }^{393}$ In its cost-benefit or Hand formula incarnation, negligence requires two calculations: first, the expected harm if a precaution is not taken; and, second, the cost of taking the precaution. In contrast, strict liability requires a calculation only of the actual harm the plaintiff has incurred, without any need to determine the cost of taking precautions. Thus, strict liability requires one less calculation-and a less complicated one at that (actual as opposed to expected harm). For this reason, strict liability is thought to reduce decision costs. Nevertheless, there is an offsetting factor: strict liability is likely to generate more cases, since defendants are liable

391. See, e.g., Shawn J. Bayern, The Limits of Formal Economics in Tort Law: The Puzzle of Negligence, 75 BROOK. L. REV. 707, 715-16 (2010) ("[E]arly on, economic analysts of law recognized that negligence rules and strictliability rules provided similar incentives to injurers."); Richard A. Epstein, Causation-In Context: An Afterword, 63 CHI.-KENT L. REv. 653, 661 (1987) ("[T] he incentive effects of both the strict liability rule and the negligence rule-in the situation of private necessity or not-are essentially identical.").

392. See, e.g., Guido Calabresi \& Jon T. Hirschoff, Toward a Test for Strict Liability in Torts, 81 YALE L.J. 1055, 1060 (1972); Stephen G. Gilles, Negligence, Strict Liability, and the Cheapest Cost-Avoider, 78 VA. L. REv. 1291, 1297-98 (1992).

393. William M. LANDES \& RichaRd A. POSNER, THE Economic STRUCTURE OF TORT LAW 65-66 (1987); Alan O. Sykes, Strict Liability versus Negligence in Indiana Harbor, 74 U. CHI. L. REV. 1911, 1921-22 (2007). 
even if precautions are not cost-justified. ${ }^{394}$ In other words, the reduction in decision costs per case must be weighed against the cost of processing more cases, making it on balance unclear which standard generates higher decisional costs. In any event, our proposal obviously requires a determination not only of whether the defendant caused the harm, but also of how (i.e., so that a determination is made about whether the conduct was subject to a regulation). This second inquiry potentially adds to decision costs. It is impossible to determine, however, whether the hybrid would impose higher decision costs than either a pure negligence or a strict liability regime, since it would incorporate elements of both.

\section{c. Incentives to Reduce the Level of Activity}

Although negligence and strict liability provide identical incentives to take efficient precautions, strict liability creates a greater incentive to reduce the level of potentially harmful activity. ${ }^{395}$ Unlike negligence, strict liability imposes liability even if all efficient precautions are taken. This liability-even for non-negligent conduct-can motivate defendants to avoid potentially harmful conduct. Relatedly, strict liability creates stronger incentives to innovate. Since defendants bear all accident costs, they are motivated to find new ways to minimize them. ${ }^{396}$ Negligence, by contrast, spares defendants from liability as long as they take identified precautions, which usually are grounded in existing practices. If the status quo is enough to avoid liability, there is less incentive to improve upon it. This difference motivates us to incorporate aspects of strict liability in our hybrid proposal (through negligence per se and res ipsa loquitur). After all, since fracturing in shale is relatively new, it is important to create incentives for energy companies to take water contamination risks into account in deciding where (and, indeed, whether) to drill and to develop risk-reducing innovations.

394. LAANDES \& POSNER, supra note 393, at 65.

395. Steven Shavell, Strict Liability Versus Negligence, 9 J. LEGAL STUD. 1, 7 (1980); see Indiana Harbor Belt R.R. Co. v. Am. Cyanamid Co., 916 F.2d 1174,1177 (7th Cir. 1990) ("By making the actor strictly liable ... we give him an incentive, missing in a negligence regime, to experiment with methods of preventing accidents that involve not greater exertions of care, assumed to be futile, but instead relocating, changing, or reducing (perhaps to the vanishing point) the activity giving rise to the accident.").

396. COOTER \& ULEN, supra note 335, at 340. 


\section{d. Incentives for Plaintiffs}

Negligence and strict liability create different incentives for plaintiffs. Under negligence, plaintiffs cannot collect from defendants who have taken efficient precautions. ${ }^{397}$ In this circumstance, plaintiffs have a greater incentive to adjust their own behavior to avoid injury, an incentive that does not arise to the same extent under strict liability ${ }^{398}$ At the margin, it is of course helpful to motivate plaintiffs to take precautions, although in the context of fracturing, their largely passive role reduces the importance of this variable.

\section{e. Coordination with Best Practices Regulation: Three Liability Rules}

Although the analysis so far might suggest a mild preference for strict liability (given its incentive effects on activity levels and innovation), a key advantage of a negligence framework is it can be adapted more readily to reinforce best practices regulation, which, as discussed above, is an important element of our regulatory strategy. Indeed, we can use a negligence framework to encourage both compliance with such rules and the development of new rules. At the same time, we can couple the negligence framework with the doctrines of negligence per se and res ipsa loquitur so that it operates functionally like strict liability in settings that are not yet governed by best practices regulations.

Let us now take a closer look at the three liability rules. Under the doctrine of negligence per se, any violation of a statutory or regulatory standard of care that causes harm automatically gives rise to liability. ${ }^{399}$ In effect, the tribunal forgoes any

397. KENNETH S. ABRAHAM, THE FORMS AND FUNCTIONS OF TORT LAW 194 (4th ed. 2012) (noting that a negligence regime can be characterized as "strict liability for the victims of non-negligently caused accidents").

398. If plaintiff recoveries are reduced by comparative negligence, then this doctrine motivates plaintiffs to take precautions-even if it is paired with strict liability, as it is in some states. See Daly v. Gen. Motors Corp., 575 P.2d 1162, 1168-69 (Cal. 1978). Comparative negligence has been adopted by legislation and occasionally by judicial decision in 46 states. VICTOR E. SCHWARTZ, COMPARATIVE NEGLIGENCE, 517-22 (5th ed. 2010). The proliferation of comparative negligence clearly diminishes the advantage of negligence in motivating plaintiffs to avoid harm.

399. RESTATEMENT (THIRD) OF TORTS: LIAB. FOR PHYSICAL AND EMOTIONAL HARM $\S 14$ (2010) ("An actor is negligent if, without excuse, the actor violates a statute that is designed to protect against the type of accident the actor's conduct causes, and if the accident victim is within the class of persons the statute is designed to protect."); id. at cmt. a ("statute" should be broadly 
direct comparison of the benefits and costs of taking particular precautions, using the regulatory determination instead. As a result, any violation of a best practices regulation that causes water contamination would yield a finding of negligence. This doctrine provides a powerful incentive for firms to comply with best practices regulations. It also reduces the factfinder's decision costs by eliminating the need for a cost-benefit analysis.

The mirror image of negligence per se is the regulatory compliance defense. Just as a violation establishes liability, compliance with a regulation can shield the defendant from liability. ${ }^{400}$ For example, if a best practices regulation requires a four-inch cement casing, the plaintiff cannot argue that reasonable care requires six inches. To be sure, the regulatory compliance defense would not, however, stop a plaintiff from showing that the energy company was negligent in the way it implemented the required best practice. Thus, even if the well casing was the requisite four inches, the energy company could still be deemed negligent if it installed or maintained the casing improperly. Even so, the regulatory compliance defense, like the doctrine of negligence per se, provides a strong incentive to comply with best practices regulations.

The regulatory compliance defense comes in two versions: a strong version, in which the regulatory standard serves as a "ceiling" as well as a "floor" in establishing the defendant's duty of care $;{ }^{401}$ and a qualified version, in which compliance with a regulatory standard is regarded as "evidence of nonnegligence" but is not conclusive. ${ }^{402}$ Most commentators favor the qualified version of the defense, on the ground that regulatory requirements will often lag behind the state of the art, perhaps because agencies are underfunded or become captured by the firms they are supposed to regulate. These are legitimate concerns. ${ }^{403}$ But watering down the defense reduces the incentives

defined to include administrative regulations); see Ariel Porat, Expanding $\mathrm{Li}$ ability for Negligence Per Se, 44 WAKE FOREST L. REV. 979 (2009).

400. E.g., Ramirez v. Plough, Inc., 863 P.2d 167 (Cal. 1993).

401. See Richard C. Ausness, The Case for a "Strong" Regulatory Compli. ance Defense, 55 MD. L. REV. 1210 (1996).

402. RESTATEMENT (THIRD) OF TORTS: LIAB. FOR PHYSICAL AND EMOTION. AL HARM § 16 (2010); Robert L. Rabin, Reassessing Regulatory Compliance, 88 GEO. L.J. 2049 (2000); Teresa Moran Schwartz, The Role of Federal Safety Regulations in Products Liability Actions, 41 VAND. L. REV. 1121 (1988).

403. A related problem is that best practices regulations will generally be formulated as minimum standards of safety. Relying on a breach of such a standard to establish negligence, as under the negligence per se doctrine, is unproblematic, because the defendant has clearly fallen below the minimum 
of the industry to support the development of additional best practices regulations. It also overlooks the dangers of allowing courts and juries to second-guess regulators in matters that entail considerable scientific uncertainty, and ignores the substantial savings in litigation costs from adopting regulatory standards as the measure of reasonable care. ${ }^{404}$ On balance, we prefer a relatively robust version of the regulatory compliance defense, leaving open the possibility of overriding it in unusual circumstances. Thus, we would suggest that compliance with best practices regulations should create a presumption that the defendant has exercised reasonable care with respect to the conduct governed by the regulation, but should be subject to rebuttal if the plaintiff could show that the relevant best practices rule deviates substantially from the rule followed in other oil and gas jurisdictions. ${ }^{405}$

What if water is contaminated through a pathway that is not governed by any best practices regulation? In this circumstance, we would use the burden-shifting rule associated with the common law doctrine of res ipsa loquitur. ${ }^{406}$ Specifically,

required standard of care. Relying on compliance with a minimum standard to establish the absence of negligence is potentially problematic, however, if the minimum standard falls below the standard that would be established using the cost-benefit approach of the Hand formula. See Mark Geistfield, Tort Law in the Age of Statutes, 98 IOWA L.REV. (forthcoming 2014). Although it is not clear how often this theoretical possibility would emerge with clarity in actual practice, it provides an additional reason to adopt a qualified rather than complete version of the regulatory compliance defense.

404. Ausness, supra note 401, at 1265-66.

405. The use of best practices regulations to establish negligence per se or regulatory compliance could be mandated by statute, in which case these understandings would of course be binding on the liability tribunal as a matter of legislative supremacy. Absent such legislation, we believe tribunals should defer to best practices regulations as a matter of comity to the legislature or the agency exercising delegated authority that has adopted these regulations. See Geistfield, supra note 403. Because such deference would be grounded in comity, the tribunal would not need to consider such questions as whether it was a purpose of the regulation to protect the plaintiff or the defendant. The tribunal would also be free, in appropriate cases, to conclude that the regulation does not reflect a considered judgment about the appropriate degree of precaution necessary to establish or defeat a claim of negligence.

406. RESTATEMENT (THIRD) OF TORTS: LIAB. FOR PHYSICAL AND EMOTIONAL HARM $\S 17$ (2010) ("The factfinder may infer that the defendant has been negligent when the accident causing the plaintiff's harm is a type of accident that ordinarily happens as a result of the negligence of a class of actors of which the defendant is the relevant member."). Courts have traditionally required, in addition, that the agency or instrumentality that caused the harm be "within the exclusive control of the defendant" and that the injury "must not have been due to any voluntary action or contribution on the part of the 
provided the evidence eliminates other responsible causes, including the conduct of the plaintiff and third persons, the fact finder would be authorized to infer that the energy company's negligence caused the contamination-in effect, without any direct evidence of such negligence. Although this inference would satisfy the plaintiff's burden of proof in showing negligence, the defendant can try to rebut it, for instance, by arguing that the contamination was caused by an Act of God (like an earthquake), or was an inevitable accident that would have occurred even if fracturing had not taken place in the vicinity. ${ }^{407}$

In practice, this application of res ipsa loquitur would operate something like strict liability for pathways of contamination not governed by best practices regulations. Defendants would rarely have the information needed to rebut the presumption-for example, about movements deep underground that may have caused fracturing fluid or methane to migrate from shale seams aquifers. Thus, they would likely be found negligent. By subjecting energy companies to a high certainty of liability where there is no applicable regulation, we give them yet another incentive to support the development of new risk-reducing technologies or practices which, in turn, would provide the basis for additional best practices regulations.

A further reason to use something like de facto strict liability for unregulated pathways of contamination is to ensure that compensation is available to injured parties. Compensation is especially important where insurance is unavailable. Since fracturing in shale deposits is relatively new and there is uncertainty about the magnitude of the relevant risks, ${ }^{408}$ insurance companies are unlikely to issue landowners policies covering water contamination, at least for now. A relatively secure right to compensation for risks that are especially uncertain could also marginally help reduce public apprehensions about fracturing. ${ }^{409}$

plaintiff." W. PAGE KeETON ET AL., PROSSER \& KEETON ON THE LAW OF TORTS 244 (5th ed. 1984).

407. See RESTATEMENT (THIRD) OF TORTS: LIABILITY FORPHYSICAL AND EMOTIONAL HARM $\$ 17 \mathrm{cmt}$. g (2010).

408. See, e.g., supra Part IV.A.6.

409. As George Fletcher has argued, strict liability is appropriate for nonreciprocal risks: that is, when defendants are imposing risks on plaintiffs, but plaintiffs are not imposing comparable risks on defendants. George P. Fletcher, Fairness and Utility in Tort Theory, 85 HARV. L. REV. 537, 541-48 (1972). Although energy companies create a risk that a landowner's water will be contaminated, landowners do not impose a comparable risk on energy companies (other than the risk of liability). As a result, fracturing presents the sort of 
Which sorts of risks would be governed by one of the per se rules based on best practices regulations and which would be governed by res ipsa loquitur? By and large, the per se rules would apply to those water contamination risks that are best understood and have the highest probability of occurring, such as surface spills, leaks of fracturing fluid or methane through well casings, and improper disposal of flow-back or produced water. ${ }^{410}$ Conversely, those risks that are less well understoodand that would appear, based on what we know so far, to present lower probabilities of occurring-would be governed by res ipsa loquitur. This would include migration of methane or fracturing fluid from shale seams, and contamination produced by vibrations that dislodge pockets of gas or contaminants already present in aquifers or water wells.

\section{Plaintiff Fault and RELEASES From Liability}

We do not expect plaintiff fault to be an issue in the typical water contamination case, where the energy company is active and the landowner is passive. But the issue could arise in some cases. For instance, assume that an abandoned well on plaintiff's property contributed to the contamination, and the plaintiff knew about the well but did not disclose it before the energy company began fracturing. In this sort of case, energy companies should be allowed to raise the plaintiff's comparative negligence as a defense. Liability should be apportioned between the plaintiff and the defendant based on how much each contributed to the contamination. ${ }^{411}$ Likewise, if the plaintiff invokes a health effect, but has also engaged in unhealthy behavior (e.g., smoking), the energy company could argue comparative negligence.

In some cases, we would also recognize a defense of assumption of risk. In theory, one could hold that the plaintiff assumed the risk simply by signing a mineral lease, with the expectation of sharing in oil and gas revenues. Given the large uncertainties about the risks associated with fracturing, we are reluctant to endorse any such broad defense. If, however, a plaintiff has signed a lease that includes a written (and prominently disclosed) release of liability for water contamination-

nonreciprocal risk that favors strict liability.

410. For discussion of these risks see supra Parts IV.A-D.

411. To be clear, we do not recommend contributory negligence, which affords a complete defense to liability, since this might undercut defendants' incentives to take precautions. 
and especially if this entitles the plaintiff to extra consideration-we would respect the release.

\section{Measure of Damages}

Any harm incurred by the plaintiff should be measured accurately ${ }^{412}$ A key element of harm will be damage to the land, which ordinarily is measured by the decline in the land's fair market value. Yet this measure could undercompensate landowners by ignoring their subjective valuation of the land; after all, the fact that owners have not sold it means they value it more than its market value. ${ }^{413} \mathrm{~A}$ partial solution is to let the plaintiff choose instead to recover the cost of restoring access to potable water, for instance, by decontaminating the existing well, digging a new one, or piping or trucking in water. ${ }^{414}$ In addition, damages for any health effects will also have to be calculated. This sort of damages is, of course, familiar in other types of litigation, and is sometimes accompanied by damages for pain and suffering, loss of consortium, and other noneconomic damages. ${ }^{415}$

412. Accurate compensatory damages are more important under strict liability than under negligence. Under the Hand formula, as long as the compensation is sufficiently large to influence the conduct of the defendant, under- or over-compensation arguably does not matter: the defendant will take only those precautions that are cost-justified. Kyle D. Logue, Coordinating Sanctions in Tort, 31 CARDOZO L. REV. 2313, 2324 (2010). Under strict liability, by contrast, the defendant will take efficient precautions only if the measure of damages accurately mirrors the costs incurred by the plaintiff. If the damages are too low, the defendant will take insufficient precautions; if they are too high, the defendant will take excessive precautions. Since our liability scheme will operate in part like a strict liability regime-relying extensively on negligence per se and res ipsa loquitur-accuracy in measuring damages is important to maintaining correct incentives for defendants.

413. Ignoring the subjective value of landholdings may work two harms: first, by undercompensating property holders and thereby creating perverse incentives for injury; second by denigrating the personal connections that render land important to owners in the first place. Christopher Serkin, The Meaning of Value: Assessing Just Compensation for Regulatory Takings, 99 NW. U. L. REV. 677, 722-23 (2005).

414. We do not believe the difference in these damage measures would be so great as to render the "cost of cure" grossly disproportionate to the benefit to the plaintiff, at least in the usual case. At most, the restorative measure would be the cost of installing a large tank and paying periodically to truck in water to fill it. Cf. Peevyhouse v. Garland Coal \& Mining Co., 382 P.2d 109 (Okla. 1962) (refusing to award cost of cure when the fair market value measure of damages was $\$ 300$ and the cost of restoring land disrupted by mining was $\$ 25,000$ ).

415. See, e.g., Ronen Avraham, Putting a Price on Pain-and-Suffering Damages: A Critique of the Current Approaches and a Preliminary Proposal 
Punitive damages are another matter, since they can lead to large and unpredictable awards that can chill socially valuable activity. One potential rationale for punitive damages-the need to offset the difficulty of detecting harm ${ }^{416}$ - should not apply if our suggestions about periodic retesting and presumptions about health effects are adopted. We believe punitive damages would be appropriate for defendants who falsify reporting requirements or knowingly violate regulations insuring well integrity or preventing surface spills. However, we would preclude the award of punitive damages for defendants who are in full compliance with all best practices regulations and disclosure requirements, engage in periodic testing, and are free of any affirmative misconduct. This safe harbor rule would give energy companies an added incentive to comply with these safety-promoting rules.

\section{E. ATTORNEY's FEES}

Will competent lawyers be willing to bring cases? A contingent fee should be a sufficient inducement if the potential recovery is large enough, as, for instance, in class actions or cases involving serious health effects. ${ }^{417}$ In cases that present only property damage to individual landholdings, however, recoveries may not be sufficient to attract the contingent-fee bar. To eliminate this possibility, we can adopt a one-way fee shifting rule, like those found in the civil rights laws and the citizen suit provisions of environmental laws. ${ }^{418}$ In these regimes, if defendants are held liable, they have to pay the plaintiffs reasonable attorneys' fees. Experience with civil rights and environmental claims suggests that such a fee-shifting rule is sufficient to attract legal representation, even if damage awards are modest in scope. ${ }^{419}$

for Change, 100 NW. L. REv. 87, 87 (2006) (reporting that pain-and-suffering awards comprise fifty percent of total awards in some areas).

416. Id. at 2075.

417. Cf. Janet C. Alexander, Contingent Fees and Class Actions, 47 DEPAUL L. REV. 347, 350 (1998) (describing a benefit of contingent fees as being access to representation for those who otherwise would not have it).

418. See, e.g., 42 U.S.C. $\S 1988$ (b) (2000) (civil rights suits); Clean Water Act, 33 U.S.C. § 1365(d) (2006); Safe Drinking Water Act, 42 U.S.C. $\$ 6972(\mathrm{e})$ (2006).

419. Martin A. Schwartz, Attorney's Fees in Civil Rights Cases-October 2009 Term, 27 TOURO L. REV. 113, 114-15 (2011). 


\section{F. INSOLVENCY RISK}

Liability regimes cannot achieve their deterrence and compensation goals if defendants are insolvent when the action is brought. In general, we think the risk of insolvency is low, if only because any contamination from a particular oil or gas well will probably be localized, and this will largely eliminate the prospect of catastrophic liability. Yet the cumulative effect of many incidents of contamination could create at least some risk of insolvency, especially if health effects emerge. In addition, this insolvency risk could increase with time. If water contamination arises only years after fracturing (e.g., because it takes time for chemicals to migrate), the energy company might be gone by the time the problem comes to light.

The standard private solutions to insolvency risk are bonding and insurance. ${ }^{420}$ Bonding is common in the oil and gas industry to ensure proper well closure and site remediation once drilling is over. These bonds are commonly required by mineral leases and, in some states, by law. For instance, energy companies often can secure a drilling permit only if they post a bond or otherwise demonstrate their solvency. This makes sense. ${ }^{421}$ At least one state, Maryland, has required that energy companies show evidence of insurance before they may undertake oil or gas drilling activity. ${ }^{422}$

Solvency is less of an issue, moreover, as an increasing share of shale oil and gas production is conducted by major companies. Large production companies are gradually replacing the small and independent firms that pioneered this practice. ${ }^{423}$ Even the small companies are likely to partner with large and well capitalized well servicing companies, which build the wells and engage in fracturing. ${ }^{424}$ There is some evi-

420. See generally Klass \& Wilson, supra note 255, at 160-64 (explaining the ways bonding and insurance are used to manage risk).

421. See, e.g., Heather Ash, EPA Launches Hydraulic Fracturing Study to Investigate Health and Environmental Concerns While North Dakota Resists Regulation: Should Citizens Be Concerned?, 87 N.D. L. REv. 717, 737-38 (2011) (comparing North Dakota's bonding requirements to Pennsylvania's).

422. MD. CoDE ANN., Envir. § 14-111(7) (West 2013). For a discussion, see Hannah J. Wiseman \& David A. Dana, A Market Approach to Regulating the Energy Revolution: Assurance Bonds, Insurance, and the Certain and Uncertain Risks of Hydraulic Fracturing, 99 IOWA L. REV. (forthcoming 2014).

423. See Daniel Gilbert \& Russell Gold, As Big Drillers Move in, Safety Goes Up, WALL ST. J., Apr. 2, 2013, at A1.

424. In 2003-which was early in the development of the practice of fracturing in shale beds-three companies (Halliburton, Schlumberger, and BJ Services Company) performed $95 \%$ of all fracturing services in the United 
dence, moreover, that larger and better capitalized companies generally make fewer mistakes and use safer, state of the art practices. ${ }^{425}$

If insolvency turns out to be a problem, a mixed liability/government insurance regime may be needed. The Price Anderson Act, which applies to nuclear power, is one model; ${ }^{426}$ the Oil Pollution Act, governing oil spills, is another. ${ }^{427}$ In this spirit, any energy company that engages in fracturing could be required to contribute to a general insurance fund, which would cover the damages if the responsible energy company is insolvent. If the fund is exhausted, taxpayers would make up the difference. In other words, the first recourse would be the firm responsible. But if it cannot satisfy the judgment, the insurance fund would step in, backstopped by the government. To mitigate moral hazard, firms should be charged experience-based fees, so that those with a record of accidents have to pay more.

\section{IMPLEMENTATION OPTIONS}

So far, our analysis has focused on the functional characteristics that our proposed regime should have. We now turn to the separate question of institutional choice, namely, which level of government should implement it (federal, state, or local) and which branch should do so (legislature, administrative agency, or court).

In considering these issues, we add an assumption that has

States. See EPA 2012 PROGRESS REPORT, supra note 4, at 39. More companies have begun engaging in pressure pumping, so that this sector has become more competitive. Alison Sider, Fracking Firms Face New Crop of Competitors, WALL ST. J., July 9, 2013, at B6. Even so, the Department of Justice has begun an antitrust investigation of the pressure pumping industry. Alison Sider, U.S. Starts Antitrust Probe of Pressure-Pumping Sector, WALL ST. J., July 24, 2013, http://online.wsj.com/article/SB1000142412788732361070457862660257 2779248.html.

425. Daniel Gilbert \& Russell Gold, As Big Drillers Move In, Safety Goes $U p$, WALL ST. J., Apr. 2, 2013, at A1 ("Regulators and some environmentalists say the multinationals bring more rigorous approaches, mindful that one big mistake can affect their ability to operate everywhere."); $i d$. ("The rate of environmental violations has steadily dropped as major energy companies have bought up smaller drillers, according to a Journal review of Pennsylvania Department of Environmental Protection inspection records for Marcellus operations from 2008 to $2012 . ")$.

426. 42 U.S.C. $\$ 2210$ (2006). For a general overview of the Price Anderson Act, amendments, and implementing regulations, see Dan M. Berkovitz, PriceAnderson Act: Model Compensation Legislation?-The Sixty-Three Million Dollar Question, 13 HARV. ENVTL. L. REV. 1 (1989).

427. 33 U.S.C. $\$ 2712(2006)$. 
not featured in our analysis so far: historical practice will have significant influence over these allocations of authority. Institutions that have regulated issues in the past will have a presumptive claim to do so in the future, based on their expertise, their relationships with important interest groups, and their natural inclination to protect their turf. Of course, if the status quo were severely dysfunctional, we would recommend a change. But as we will suggest, reasonable normative arguments support the existing allocation of authority.

Another preliminary point is that ambiguity about the ultimate assignment of authority can be a virtue. The threat of enhanced federal regulation of fracturing, for instance, may motivate states to invigorate their regulatory systems. ${ }^{428}$ Likewise, pressure from local governments which may be eager to regulate fracturing may cause states to reconsider their policies. ${ }^{429}$ Indeed, in the same way that we do not yet have enough information to adopt best practices regulations for all pathways of contamination, we also should not rush to finalize the allocation of regulatory authority. In the face of pervasive uncertainty, the existing alignment of authority is a sensible place to start, and it can be revisited if new information justifies a change.

\section{A. JURISDICTIONAL SCOPE}

\section{Historical Practice}

Currently, states have principal regulatory responsibility over oil and gas production as well as groundwater. Indeed, states have been primarily responsible for oil and gas regulation ever since Colonel Drake erected his first oil well in western Pennsylvania in the nineteenth century. ${ }^{430}$ This is because oil and gas production involves difficult issues of property law, including allocating oil and gas reserves among different landowners, as well as regulating the common pool problem and the incentives for waste created by the rule of capture. As a result, every state where fracturing is taking place has an oil and gas commission. ${ }^{431}$

428. Kurth et al., supra note 258 , at 174-75.

429. Cf. id. at $156-57$.

430. Cf. Benincasa, supra note 11 , at 8,9 (discussing state control over oil and gas regulation for more than a century).

431. Cf. Kurth et al., supra note 258, at 65-154 (detailing state regulations of fracking). Although Utah does not specifically regulate fracking, it does 
In contrast, the federal government has played almost no role in regulating oil and gas production on private land. ${ }^{432}$ Although it regulates production on federal lands through the $\mathrm{Bu}$ reau of Land Management (BLM) of the Department of Interior, historically the BLM has largely tracked the regulations of the state where federal lands are located. ${ }^{43}$ Another division of the Department of the Interior regulates offshore drilling. ${ }^{434}$ Although environmentalists often criticize the lack of federal oversight-describing exemptions from federal environmental law as "loopholes"-an alternative explanation is that states were already regulating these issues when these statutes were enacted, and there was no perceived need to replace them. ${ }^{435}$

The regulation of groundwater has a similar history. Again, the states' role emerged from property law. Starting with a simple rule of capture by surface owners, states have evolved toward either "reasonable use" regimes where groundwater is plentiful or more elaborate prior appropriation and permitting systems in arid areas. ${ }^{436}$ Today, many state water authorities regulate the use of pesticides to protect groundwater, a number of states have wellhead protection programs, and a handful of states mandate groundwater monitoring. ${ }^{437}$ The Federal Clean Water Act generally leaves groundwater to state regulation, ${ }^{438}$ except that the federal Safe Drinking Water Act

have an oil and gas commission. Id. at 140. See Utah Oil and Gas: Division of Oil, Gas and Mining, UTAH DEP'T OF NATURAL RES., http://oilgas.ogm.utah .gov (last visited Oct. 17, 2013).

432. See David B. Spence, Federalism, Regulatory Lags, and the Political Economy of Energy Production, 161 U. PA. L. REV. 431, 477 (2013).

433. BLM is in the process of completing a major rulemaking to establish preliminary best practices regulations for fracturing activity on federal lands. Oil and Gas; Well Stimulation, Including Hydraulic Fracturing, on Federal and Indian Lands, 77 Fed. Reg. 27,691 (May 11, 2012) (to be codified at 40 C.F.R. pt. 3160).

434. Once called the Minerals Management Service, it was reorganized and renamed the Bureau of Ocean Energy Management, Regulation, and Enforcement (BOEMRE) after the Deepwater Horizon accident. See Reorganization of Title 30, Code of Federal Regulations, 75 Fed. Reg. 61,051 (Oct. 4, 2010).

435. For a general discussion of the exemptions fracking operators have secured in Congress, see Hannah Wiseman, Regulatory Adaptation in Fractured Appalachia, 21 VILL. ENVTL. L.J. 229, 242-44 (2010).

436. Cf. A. DAN TARLOCK, LAW OF WATER RIGHTS AND RESOURCES $\$ \S 4: 1$, 4:7-12, 6:1, 4:28-32 (John Damico \& Barbara J. Hagan eds., 2013).

437. See generally PaUl TESKe, REgulation IN THE States 184-92 (2004) (explaining factors affecting state decisions to pass these regulations).

438. See generally Jason R. Jones, The Clean Water Act: Groundwater Regulation and the National Pollutant Discharge Elimination System, 8 DICK. J. 
(SDWA) offers a partial exception (primarily) for public water systems. ${ }^{439}$ After the Eleventh Circuit applied the SDWA's Underground Injection Control program to fracturing operations, ${ }^{440}$ Congress amended the act to exempt fracturing. ${ }^{41}$ Injection of waste water is still covered by the program, as is the use of diesel fuel in fracturing. This has again been decried as a "loophole," ${ }^{442}$ but it can also be seen as restoring the status quo ante existing before this decision, in which states regulated groundwater quality unless public water systems were implicated. ${ }^{443}$

\section{Policy Justifications for State Regulation}

Of course, if the states' historical role is unjustified on policy grounds, we should change it. In theory, we could try to resolve this question based on an abstract assessment of the effects of inter-jurisdictional competition. Does environmental federalism inspire "races to the bottom" or "races to the top"? Likewise, does NIMBYism (the "not in my backyard" syndrome) affect one level of government more than others? ${ }^{445}$ These debates often turn on competing hypotheses-built on conflicting assumptions-about the distribution of interest group influence at different levels of government. ${ }^{446}$ At the state and local level, some observers contend that energy companies have captured regulators; others claim landowners ultimately call the shots. At the national level, some think oil and gas interest groups

ENVTL. L. \& POL'Y 93. 101 (1999).

439. See 42 U.S.C. $\S 300 \mathrm{~g}-1$ (b) 8 (2006) (providing authority to regulate public water systems and groundwater).

440. Legal Envtl. Assistance Found., Inc. v. EPA, 118 F.3d 1467, 1478 (11th Cir. 1997).

441. See sources cited supra note 278.

442. See, e.g., Editorial, The Halliburton Loophole, N.Y. TIMES, Nov. 3, 2009, at A28.

443. See Hannah Wiseman, Regulatory Adaptation in Fractured Appalachia, 21 VILL. ENVTL. L.J. 229, 246 (2010).

444. Compare Kirstin H. Engel, State Environmental Standard-Setting: Is There a "Race" and Is it "to the Bottom"? 48 HASTINGS L.J. 271 (1997) (defending the race to the bottom thesis), with DAVID VOGEL, TRADING UP: CONSUMER AND ENVIRONMENTAL REGULATION IN A GLOBAL ECONOMY 259 (1995) (arguing for race to the top).

445. See, e.g., William A. Fischel, Why Are there NIMBYs?, 77 Land ECON. 144,145 (2001) (arguing that homeowners comprise most NIMBYs and that homeowners exert "major political force" at a local level).

446. Richard L. Revesz, Rehabilitating Interstate Competition: Rethinking the 'Race-to-the Bottom' Rationale for Federal Environmental Regulation, 67 N.Y.U. L. REV. 1210 (1992). 
have undue clout; others claim that environmentalists have disproportionate influence. We have no unique empirical insights that would allow us to endorse or condemn state regulation based on one of these inter-jurisdictional competition models. ${ }^{447}$ Instead, we focus on four other policy considerations.

\section{a. Matching Principle}

We believe a regulatory jurisdiction generally should correspond to the geographic scope of the externality, sometimes known as the "matching principle." 448 Thus, the federal government should regulate interstate pollution, the states should regulate spillovers confined to a single state, and localities should regulate externalities with local effects. This assures that the regulator considers all costs and benefits of the activity without ignoring those borne by outsiders, while simultaneously preserving flexibility to account for local conditions, traditions, and preferences. The Europeans call this the principle of subsidiarity. ${ }^{49}$ In this spirit, groundwater contamination from oil and gas production is generally assumed to be a local issue. Contamination from fracturing is likely to affect only water that is close to the relevant drilling or waste disposal. ${ }^{450}$ Cases in which an aquifer straddles more than one county or crosses a state line are thought to be rare. If these assumptions are correct, the scope of the externality suggests that localities should take the lead, perhaps as an adjunct to zoning and other land use controls. Of course, there is uncertainty about the possible scope of contamination, like much else. If it turns out that incidents of contamination affect multiple jurisdictions, this variable should be reconsidered.

447. For an (inconclusive) debate about these issues, compare David B. Spence, Federalism, Regulatory Lags, and the Political Economy of Energy Production, 161 U. PA. L. REv. 431 (2012) (concluding that state regulation is optimal) with Michael Burger, Response, Fracking and Federalism Choice, 161 U. PA. L. REV. ONLINE 150 (2013) (arguing for federal regulation).

448. See Henry N. Butler \& Jonathan R. Macey, Externalities and the Matching Principle: The Case for Reallocating Environmental Regulatory Authority, 14 YALE L. \& POL'Y REV. 23, 25 (1996); Richard O. Zerbe, Optimal Environmental Jurisdictions, 4 ECOLOGY L.Q. 193, 204 (1974).

449. See George Bermann, Taking Subsidiarity Seriously: Federalism in the European Community and the United States, 94 COLUM. L. REV. 331, 339 (1994).

450. Spence, supra note 256, at 492-93 (concluding that groundwater contamination issues "are local"). 


\section{b. Economies of Scale}

Economies of scale in regulation are also important. ${ }^{451}$ Complex issues require a staff of experts, and a tax base that can support them. All else being equal, then, more complex issues are likely to be addressed centrally, where there is greater capacity to raise revenue and less duplication of effort. Indeed, the best justification for the SDWA-and the federal role in regulating local public drinking water systems-is the technical expertise required, although actual enforcement ordinarily remains with the states. ${ }^{452}$ By analogy, scale economies might justify federal regulation of fracturing. After all, the technology is complex, and the federal government-and, in particular, EPA-has a comparative advantage in mobilizing resources for field research, gathering and comparing data from across the country, and so forth.

Cutting against this, however, is EPA's lack of expertise in oil and gas production. States have much more experience with this industry, as do other parts of the federal government (e.g., BLM and BOEMRE). Likewise, federal expertise about groundwater hydrology is concentrated in the U.S. Geological Survey, another unit of the Department of the Interior (although EPA also has relevant experience from administering CERCLA, RCRA, and the SDWA). In regulating fracturing, then, EPA would need to build out its expertise substantially. Federal regulation also tends to be ponderously slow, perhaps in part because the stakes are higher and consequently more interest groups get involved. ${ }^{453}$ While the states have fewer resources overall, they have a significant head start in regulating oil and gas and, to a lesser extent, groundwater. Although this expertise is divided among the states, and there is undoubtedly

451. See Richard B. Stewart, Pyramids of Sacrifice? Problems of Federalism in Mandating State Implementation of National Environmental Policy, 86 YALE L. J. 1196, 1212 (1977); Daniel C. Esty, Revitalizing Environmental Federalism, 95 MiCH. L. REV. 570, 614-15 (1996) ("[T] echnical capacity generally will be weakened by devolution . . . . Data collection and quality control, fate and transport studies, epidemiological and ecological analyses, and risk assessments all represent highly technical activities in which expertise is important and scale economies are significant."); Buzbee, supra note 363, at 11112.

452. Cf. Sarah E. Lewis, The 1986 Amendments to the Safe Drinking Water Act and Their Effect on Groundwater, 40 SYRACUSE L. REV. 893, 894-95 at n.17 (1989) (mentioning a major motivation argued by proponents of the amendment as being the states lack of expertise).

453. Cf. Christopher S. Kulander, Shale Oil and Gas State Regulatory Issues and Trends, 63 CASE W. RES. L. REV. 1001, 1141 (2013). 
duplication of effort, it is also true that production technology varies significantly from one oil and gas field to another, as do groundwater conditions.

\section{c. Brandeisian Experimentalism}

The third factor, Brandeisian experimentalism, favors states and localities over the federal government. ${ }^{454}$ States have adopted diverse approaches in regulating groundwater, as well as oil and gas, because physical conditions vary dramatically, as do property rights. As a result, states (and localities) are likely to implement different liability regimes, offering a natural experiment about what works best and why. State regulators talk to each other, and are likely to emulate approaches adopted in other states that prove successful. ${ }^{455}$ Institutional mechanisms have been created to promote the exchange of information, including STRONGER (a coalition of state oil and gas regulators) and the Groundwater Protection Council (a group of state groundwater protection regulatory agencies). ${ }^{456}$

\section{d. Capacity to Adjudicate Disputes}

Finally, because our regulatory scheme incorporates a liability rule, the relevant regulatory jurisdiction must have the capacity to adjudicate disputes about water contamination $e x$ post and enforce judgments. Both the states and the federal government have judicial systems that have extensive experience with liability regimes. Localities generally do not have their own liability regimes, which is a sufficient reason to eliminate local regulation as an option. In addition to their judicial systems, states have experience with worker compensation schemes, and the federal government has a variety of specialized liability regimes, many of which are implemented by administrative agencies. ${ }^{457}$ It is not clear that either the states or

454. New State Ice Co. v. Liebmann, 285 U.S. 262, 311 (1932) (Brandeis, J., dissenting) (" $[\mathrm{A}]$ single courageous state may, if its citizens choose, serve as a laboratory; and try novel social and economic experiments without risk to the rest of the country."). For a recent defense of state experimentalism, see JOHN O. MCGINNIS, ACCELERATING DEMOCRACY: TRANSFORMING GOVERNANCE THROUGH TECHNOLOGY 40-59 (2013).

455. Empirical studies show that state legislators are more willing to pass groundwater regulations "when neighboring states have already done so, as political uncertainty is reduced and legislators may also benefit from a 'bandwagon effect." TESKE, supra note 437, at 191.

456. For a discussion, see SURYA RAJAN, PRUDENT OIL AND GAS DEVELOPMENT AND THE EVOLUTION OF US REGULATIONS 2 (2013).

457. See, e.g., Betsy J. Grey, The Plague of Causation in National Child- 
the federal government has any strong advantage on this score.

\section{e. Policy Justifications: Summing Up}

Admittedly, these four factors do not all point in the same direction. Arguably, the geographic scope of the externality favors localities, although uncertainties about the scope of contamination would perhaps warrant centering regulation in a body having a larger jurisdictional scope, like the states. ${ }^{468}$ Economies of scale favor the federal government. ${ }^{459}$ The states are a viable compromise on both dimensions, since they are closer to the externality than the federal government and have greater expertise and resources than local governments. At the same time, states are well positioned to serve as Brandeisian laboratories and also have deep experience regulating the oil and gas industry. ${ }^{460}$ The states also have significant experience with liability regimes. Therefore, it is certainly reasonableand arguably preferable-for states to take the lead in regulating the risk of water contamination from fracturing, at least for now.

Although we believe it makes sense for states to spearhead the regulatory response to the water contamination risk, the federal and local governments can still play a role. Given the federal government's superior resources and data-gathering capacity, it is reasonable for it to sponsor studies, and to encourage the exchange of information about best practices among state regulators. ${ }^{461}$ Also, we reiterate that this analysis applies to the water contamination risk, but not to other environmental risks. Air pollution risks, for example, which could have national or even global implications, may more sensibly be regulated by the federal government than the states. That question is beyond the scope of this paper.

\section{B. IMPLEMENTING BODY}

If states are the logical locus of regulatory authority, then the relevant state regulatory commission is the logical body to

hood Vaccine Injury Act, 48 HARV. J. ON LEGIS. 343, 352-54 (2011) (detailing the compensation structure under the NCVIA).

458. Supra Part VII.A.2.a.

459. Supra Part VII.A.2.b.

460. Supra Parts VII.A.2.c., VII.A.1.

461. See Wiseman, supra note 163 , at 810 (urging that "the federal government should provide a comprehensive database of state, local, and regional oil, gas, and fracturing regulations and should separately document regulatory modifications as they occur"). 
adopt best practices regulations for water contamination risks. In most states, this is the oil and gas commission; in some it is the department of natural resources or the department of environmental protection. This follows from our pragmatic principle of starting with what already exists. Every state in which fracturing is taking place or is contemplated has a functioning regulatory commission. Although they have varying degrees of discretionary authority to adopt new regulations, all have at least some authority in matters of well construction, spacing, and safety. State water authorities are another possible locus of authority, although in many states they are thinly staffed and have little experience with oil and gas contamination issues. ${ }^{462}$ We will assume, therefore, that state commissions with current regulatory authority over oil and gas production are the place to start.

Legislation may be needed to augment their authority. As previously discussed, regulators should be empowered to require baseline testing of water quality and to compel public disclosure of chemicals used in fracturing. In addition, commissions should be authorized to adopt best practices regulations to minimize the risk of water contamination from fracturing and from the disposal of wastewater. They likewise should have authority to modify these regulations in light of experience.

A further question is who should implement the liability regime that we propose. Should it be a specialized administrative tribunal or a generalist court? ? $^{463}$ There is much to be said for using an administrative tribunal. The evidence, especially on causation, is likely to be highly technical. Recent experience suggests that administrative tribunals can minimize the costs and delay of adjudication, while achieving a high degree of satisfaction on the part of claimants. Examples include the 9-11 Commission, the BP Oil Spill Tribunal, and the arbitral awards entered under the National Childhood Vaccine Injury Act. ${ }^{464}$

462. Cf., e.g., Camille Pannu, Comment, Drinking Water \& Exclusion: A Case Study from California's Central Valley, 100 CAL. L. REv. 223, 262-63 (2012) (asserting California's water agency is "understaffed and unable to achieve consistent protection of its own agency goals").

463. See generally Richard A. Posner, Regulation (Agencies) Versus Litigation (Courts): An Analytical Framework, in REGULATION VERSUS LITIGATION: PERSPECTIVES FROM ECONOMICS AND LAW, supra note 327.

464. See September 11th Victim Compensation Fund, U.S. DEP'T of JusTICE, http://www.justice.gov/civil/common/vcffaq.html (last visited Oct. 5, 2013); Colin McDonell, The Gulf Coast Claims Facility and the Deepwater Horizon Litigation: Judicial Regulation of Private Compensation Schemes, 64 STAN. L. REv. 765, 770-72 (2012) (describing the claims process for BP oil spill 
State worker compensation systems provide another possible example. Further, if the administrative tribunal is organized as an adjunct to the body regulating the industry, it can provide valuable feedback to commissioners charged with developing best practices regulations, apprising them of issues that warrant additional attention. Finally, an administrative forum reduces uncertainty associated with judicial adjudication, especially the prospect of irrationally large damage awards from unsophisticated hometown juries.

Yet notwithstanding these advantages, it does not make sense to establish a tribunal that has nothing to do. At this point, it is not clear that fracturing will generate water contamination on a scale that will require the adjudication of very many disputes. If a case arose after a period of dormancy, moreover, the tribunal would have no body of precedents or procedural conventions to process the claim, which could lead to delay and confusion. We also doubt legislatures will be motivated to enact a new regime of this sort, unless and until it appears that fracturing has produced a significant water contamination problem. As Jim Krier recognized years ago, ${ }^{465}$ legislatures rarely are inspired to act by potential environmental risks, and are moved only when there is incontrovertible proof of harm.

Fortunately, if courts must adjudicate water contamination claims, we have an off-the-rack liability regime: the common law of torts. This brings us to a justification for tort law that is rarely encountered in the literature. Whatever its imperfections, the common law has the important advantage of providing a general form of ex post regulation applicable to virtually any new technology that presents novel and poorly understood risks. Tort law can be viewed as a default regime that allows new technologies to be implemented without advance government approval, encouraging innovation. ${ }^{466}$ And it provides a form of protection for those injured by technological innovations, while information gradually accumulates that may eventually lead to more protective ex ante regulation.

victims); Betsy J. Grey, The Plague of Causation in the National Childhood Vaccine Injury Act, 48 HARV. J. ON LEGIS. 343, 352-54 (2011) (detailing the compensation structure under the NCVIA).

465. See James E. Krier, The End of the World News, 27 LOY. L.A. L. REV. 851 (1994).

466. Samuel Issacharoff, Regulating After the Fact, 56 DEPAUL L. REV. 375, 385 (2007) (commenting that "[e]x post accountability is the prerequisite for ex ante liberalization"). 
Admittedly, the common law of tort does not have all the features we would ideally like to see in an ex post liability regime, like fee shifting and insolvency protections. Nevertheless, it is sufficiently flexible to replicate many aspects of our proposal.

Consider, first, the questions about proof of causation. Ordinarily, the plaintiff has the burden of proving causation, which will be difficult without evidence about pre-fracturing water quality. Thus, an ideal liability scheme would require periodic testing, mandatory disclosure of fracturing chemicals, and perhaps also tracer chemicals in fracturing fluid. Although common law courts cannot mandate these measures, at least before any suit is filed, they can use presumptions to get to a similar place. For instance, a court can presume that energy companies caused the contamination if they failed to conduct baseline testing before fracturing. In response, energy companies would likely seek to conduct a baseline test when negotiating mineral leases, in order to reduce the risk of future liability. Likewise, if a landowner were to block the energy company from taking water samples, the court could adopt a counterpresumption of no causation if the landowner later decided to sue. This reverse-presumption would provide a further inducement to landowners to consent to testing. At the same time, energy companies are likely to engage in periodic testing to ensure that they are not held liable for health effects, especially if courts hold that periodic testing generally insulates companies from punitive damages.

With respect to the standard of care, the common law everywhere recognizes the doctrines of negligence per se (based on the defendant's violation of a statutory or regulatory standard), and most jurisdictions recognize some form of regulatory compliance defense. ${ }^{467}$ Likewise, nearly all jurisdictions recognize some version of res ipsa loquitur. In its standard formulation, res ipsa requires that "the event must be of a kind which ordinarily does not occur in the absence of someone's negligence." ${ }^{468}$

467. See William E. Westerbeker \& Stephen R. McAllister, Survey of Kansas Tort Law: Part I, 49 U. KAN. L. REV. 1037, 1053 (2001) (comparing Kansas negligence per se to the doctrine in "every other state" and their use of criminal statutes and administrative regulations). As previously discussed, we would nudge the regulatory compliance defense in the direction of making it a presumption of reasonable care, subject to rebuttal if the state regulation is badly out of sync with the regulation in other states. See supra text accompanying notes 399-404.

468. KEETON ET AL., supra note 406, at 244. 
How can we say with confidence that the contamination, although caused by the fracturing company rather than the plaintiff or a third party, would ordinarily be due to negligence? The answer, we think, lies in the impressive track record that fracturing has amassed to date in avoiding appreciable incidents of water contamination. Fracturing, if done properly, ordinarily does not cause contamination. ${ }^{469}$ If and when it does cause contamination, it is fair to raise an inference that somewhere, somehow, the energy company was negligent. This is all that res ipsa requires. As noted, the inference is subject to rebuttal by the defendant.

There is some risk that courts will adopt a rule of strict liability to all cases involving fracturing, instead of the blended regime we recommend, perhaps on the theory that fracturing is an "abnormally dangerous" activity. Although the precedents are mixed, ${ }^{470}$ the doctrinal support for this is strained. The Restatement of Torts defines an "abnormally dangerous activity" as an activity that presents "a foreseeable and highly significant risk of physical harm even when reasonable care is exercised by all actors" and "is not one of common usage." "771 Frac-

469. Cf. Gilbert \& Gold, supra note 305 (noting that well-financed operations improve safety).

470. See, e.g., Hannah Coman, Balancing the Need for Energy and Clean Water: The Case for Applying Strict Liability in Hydraulic Fracturing Suits, 39 B.C. ENVTL. AFF. L. REV. 131, 147-54 (2012) (discussing rationales, factors involved, and applications in cases with varying outcomes). Although we recognize the parallels between fracturing and the classic English case adopting strict liability, Rylands v. Fletcher, [1868] 3 L.R. (H.L.) 330 (appeal taken from Eng.), there are important differences. In Rylands, the defendant constructed a reservoir on his land. Id. at 331-32. The weight of the water caused abandoned mining shafts below the reservoir to collapse and fill with water, which then caused mining shafts running under neighboring property to flood. Id. at 332. Contamination from fracturing, like Rylands, involves a water-borne substance propelled from one landowner's property to another. Yet the incident in Rylands, where the water completely inundated neighboring mineshafts, deprived the neighbor of possession of the mine shafts, and was in the nature of a trespass. See id. The anticipated injuries from fracturing are in the realm of nuisance rather than trespass. And nuisance has long between understood to require a balancing of interests, more akin to negligence law, not the strict liability associated with trespass.

471. RESTATEMENT (THIRD) OF TORTS: LIAB. FOR PHYSICAL AND EMOTIONAL HARM $\S 20$ (2010). The Restatement (Second) of Torts provided a more elaborate six-part test for strict liability for abnormally dangerous activities. See RESTATEMENT (SECOND) OF TORTS § 520 (1979). The additional factors required that the harm be "great," that the activity be "inappropriate[] . . . to the place where it is carried on," and that its "value to the community is outweighed by its dangerous attributes." These factors were eliminated in the Third Restatement, evidently to make the inquiry more categorical and less 
turing does not present a "highly significant risk of harm," since there is little evidence to date of water contamination from fracturing. ${ }^{472}$ Nor is it the case that reasonable care cannot reduce the risk of water contamination. Quite to the contrary, the whole premise of best practices regulation is that adoption of state of the art control technology and operational practices will significantly reduce the risk of contamination. It is also hard to argue that fracturing is not a matter of "common usage," now that an estimated two million fracturing treatments have been pumped in the United States, and virtually every new oil and gas well drilled in the U.S. today uses fracturing. ${ }^{473}$

In addition to its capacity to accommodate our proposal, the common law has the added virtue of already addressing virtually any issue that a liability regime is likely to face, including defenses based on plaintiff misconduct, joint and several liability, the measure of damages, and the enforcement of judgments. Indeed, any regime created through legislation will undoubtedly be incomplete, and will have to draw on the common law by analogy.

Finally, state legislatures often legislate on discrete issues that arise in common law adjudication. If they intervene on only one issue, our priority would be to require baseline testing of water before fracturing begins. Of course, given the Krier rule-that no environmental legislation is forthcoming until harmful effects occur ${ }^{474}$-even this may be too much to hope for. But it is worth a try, and this legislation may appeal to both energy companies and local opponents as a way to alleviate uncertainty about the effects of fracturing.

\section{CONCLUSION}

Fracturing is transforming the energy landscape of the United States. By unlocking massive reserves of natural gas and oil in shale beds and other tight rocks, fracturing is creating drilling jobs, fueling a revival of domestic manufacturing, strengthening consumer purchasing power, improving our balance of payments, enhancing our energy independence, and reducing U.S. greenhouse gas emissions.

contextual and nuisance-like.

472. See Spence, supra note 447 , at 492.

473. See Fisher, supra note 13, at 2.

474. See Krier, supra note 465. 
Yet at the same time, fracturing poses a number of risks. Some arise in conventional oil and gas drilling as well as in other economic activities, such as competition with renewable energy, traffic and congestion, air pollution, the use of significant amounts of water, and the risk of inducing earthquakes. Fracturing also poses unique risks of water contamination, which are the focus of this Article. Although there is only limited evidence of water contamination from fracturing so far, the risks are not yet fully understood and mechanisms for regulating them are not yet fully developed.

In response, we offer a general framework for regulating in the face of uncertainty and apply it to water contamination from fracturing. A core element of our proposal is best practices regulation, which should provide significant reassurance to a public worried about water contamination, as well as predictability to energy companies making large commitments of capital. Since best practices regulations cannot be adopted until we know what the best practices are, we favor such regulation only for issues that are already well understood. This includes the thickness and depth of well casings, the need for liners for storage pits and blowout preventers, and the like. Over time, as we develop more experience, the number of issues governed by such regulations is likely to grow.

Meanwhile, we can encourage the development of a robust best practices regime by backstopping it with liability rules. Under our proposed liability regime, unless an energy company is in full compliance with applicable best practices regulations, it generally would have to pay for any water contamination harms caused by fracturing operations. Such a liability system will motivate energy companies to take precautions and develop risk-minimizing innovations, and will also compensate victims. Moreover, it spares regulators the need to mandate best practices before we know enough about the risks and how to address them. A key challenge in implementing such a liability regime is to make reliable judgments about causation, and we recommend a system of information-forcing rules to inform these judgments, including baseline testing, the disclosure of fracturing chemicals, and possibly also the use of tracer chemicals. We also consider the proper measure of damages, the allocation of attorney fees, the risk that defendants will be judgment proof, as well as other issues.

Finally, we believe our proposed regime should be implemented at the state level. Although this could take the form of 
new legislation prescribing all desirable elements of the liability regime, a more realistic option, at least in the near term, is to adapt the existing common law of torts to the unique problems posed by fracturing. In our view, this blended strategyan evolving body of best practices regulation paired with a wellcrafted liability regime - can perform the vital function of protecting our water resources, while also harnessing the substantial economic, national security, and environmental advantages of the shale oil and gas revolution. 